\title{
Perceptions of directors of special education related to their knowledge and training
}

Francis J. Super

West Virginia University

Follow this and additional works at: https://researchrepository.wvu.edu/etd

\section{Recommended Citation}

Super, Francis J., "Perceptions of directors of special education related to their knowledge and training" (2005). Graduate Theses, Dissertations, and Problem Reports. 2690.

https://researchrepository.wvu.edu/etd/2690

This Dissertation is protected by copyright and/or related rights. It has been brought to you by the The Research Repository @ WVU with permission from the rights-holder(s). You are free to use this Dissertation in any way that is permitted by the copyright and related rights legislation that applies to your use. For other uses you must obtain permission from the rights-holder(s) directly, unless additional rights are indicated by a Creative Commons license in the record and/ or on the work itself. This Dissertation has been accepted for inclusion in WVU Graduate Theses, Dissertations, and Problem Reports collection by an authorized administrator of The Research Repository @ WVU.

For more information, please contact researchrepository@mail.wvu.edu. 
Perceptions of Directors of Special Education

Related to Their Knowledge and Training

\author{
Francis J. Super \\ Dissertation submitted to the \\ College of Human Resources and Education \\ at West Virginia University \\ in partial fulfillment of the requirements \\ for the degree of
}

\title{
Doctor of Education \\ in
}

Educational Leadership Studies

\author{
Paul Chapman, Ph.D., Chair \\ Paul William Rosier, Ed.D. \\ Ernest Goeres, Ph.D. \\ Sebastian Diaz, Ph.D. \\ Yvonne Santin, Ph.D.
}

Department of Advanced Educational Studies

Morgantown, West Virginia
2005

Keywords: Perceptions, Special Education, Knowledge Base, Training Copyright 2005 Francis J. Super 


\title{
ABSTRACT \\ Perceptions of Directors of Special Education Related to Their Knowledge and Training
}

\author{
Francis J. Super
}

This study investigates the perceptions of the knowledge base that are held by directors of special education. The study focuses on one main research question: What is the knowledge base special education directors feel they need to know in the field of special education? Mixed methodology, constant comparative method as described by Maycut and Morehouse (1994) and Statistical Package for the Social Sciences, is used to analyze data from a survey and interviews. Survey data was collected from 45 current special education administrators along with in-depth interview data from 6 directors. The interviewees were chosen randomly using selective sampling based on 3 sets of paired opposite factors. Both instruments are designed to gather brief demographic information and cover 3 domains of directors' perceptions: (a) special education director preparation, (b) skills learned on the job, and (c) building a better education administration program. Eighteen areas of knowledge are identified by the participants. The data from both groups of participants suggests that while graduate level education administration programs may either directly provide specific content or it is embedded in other courses, on the job experiences allow the director to expand, refine, and apply the learned knowledge through practical application. Among other areas, this study opens questions for additional research related to gender specific issues, licensure, and program changes for institutions of higher education. 


\section{TABLE OF CONTENTS}

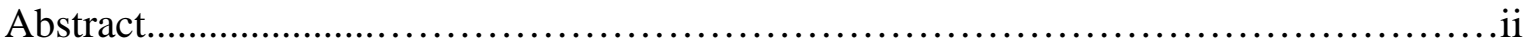

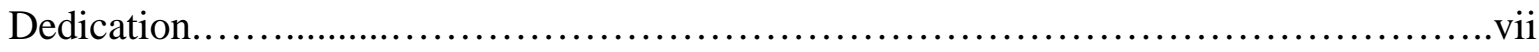

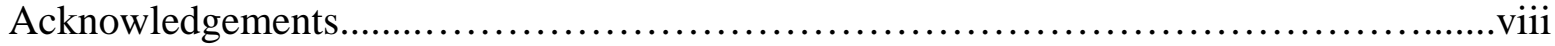

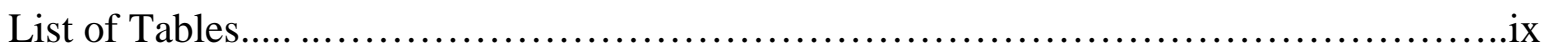

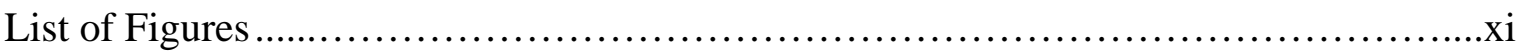

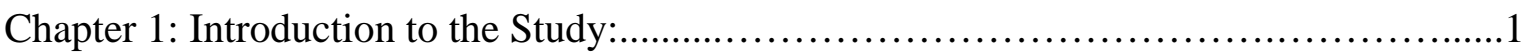

Context of the Problem..................................................................

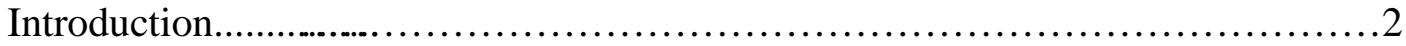

Purpose and Reason for the Study ...............................................

The Research Question................................................................

Overview of the Dissertation.....................................................

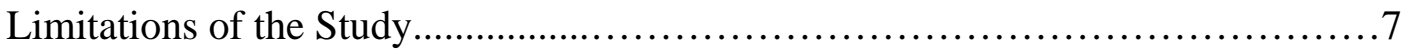

Chapter 2: Review of Related Literature...............................................

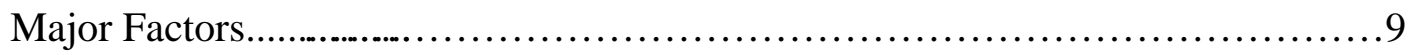

Evolution of Special Education......................................................10

Legislative and Legal History ..............................................12

Roles of the Special Education Director.............................................14

What Practitioners are Saying ..............................................22

Preparation of Special Education Administrators.....................................27

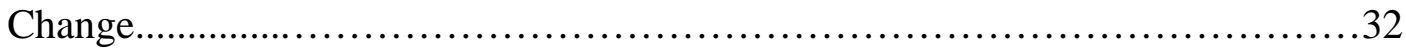

Chapter 3: Methodology:............................................................. 45

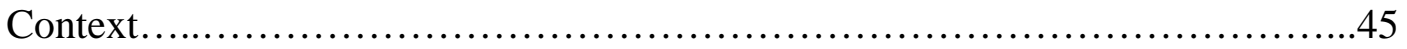




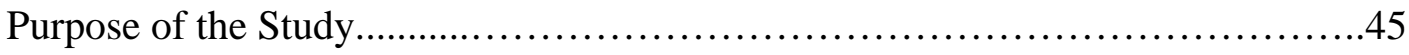

Research Question.............................................................46

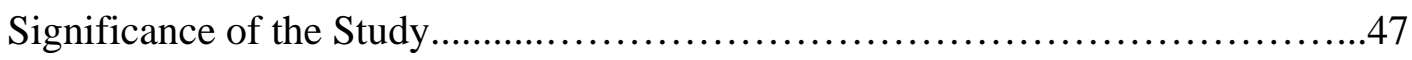

Researcher Bias..............................................................48

Research Methods and Procedures............................................. 51

Design of the Study....................................................... 52

Selection of Participants...................................................... 52

Recording and Storing Data................................................54

Data Analysis................................................................ 54

Domains for the Survey................................................... 56

Questionnaire/Personal Interviews.............................................57

Directors of Special Education Perceptions Survey..............................60

Chapter 4: Findings: .......................................................62

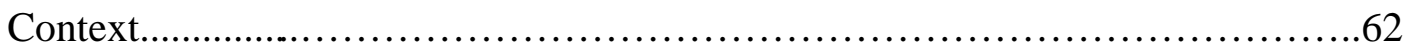

Quantitative Analysis..................................................64

Demographics for All Respondents........................................64

Demographics - All Male and Female Respondents...........................65

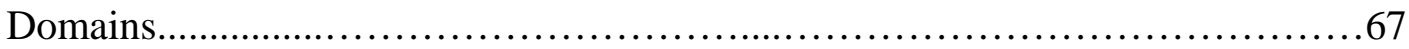

Special Education Director Preparation.........................................68

Skills Learned On-The-Job - All Respondents.................................68

Skills Learned On-The-Job - Male and Female Respondents.........................69

Building a Better Education Administration Program - All Respondents............71 
Building a Better Education Administration Program - Male and Female

Respondents

With an Endorsement.................................................... 75

Demographics for All Respondents with an Endorsement..........................75

Demographics - Males and Females with an Endorsement.........................77

Special Education Director Preparation - All Respondents with an

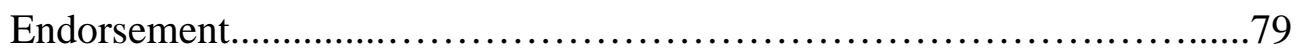

Special Education Director Preparation - Males and Females.........................79

Skills Learned On-The-Job - All Respondents with an Endorsement...................81

Skills Learned On-The-Job - All Male and Female Respondents....................83

Building a Better Education Administration Program - All Respondents with

an Endorsement.................................................... 85

Building a Better Education Administration Program - All Male and Female Respondents with an Endorsement......................................87

Without an Endorsement...................................................89

Demographics....................................................... 89

Demographics - Males and Females without an Endorsement........................89

Skills Learned On-The-Job - All Respondents..................................91

Skills Learned On-The-Job - All Males and Females................................91

Building a Better Education Administration Program - All Respondents..............93

Building a Better Education Administration Program - Male and Female

Respondents....................................................95

Qualitative Analysis....................................................97 
Interviewee Background....................................................99

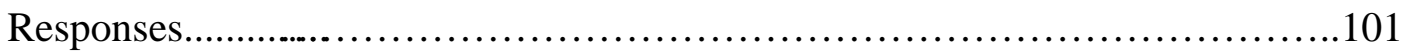

Chapter 5: Discussion, Conclusions, and Implications................................110

Discussion ............................................................... 111

Conclusions.............................................................. 114

Implications...........................................................116

Gender Issues............................................................... 118

Higher Education Institutions ........................................119

Licensure............................................................... 121

Practitioners............................................................ 123

Future Research.........................................................124

Personal Reflections on the Research Process....................................125

References................................................................... 128

Appendices..................................................................139

Appendix A - Demographics for All Respondents................................139

Appendix B - Demographics for Male Respondents ........................141

Appendix C - Demographics for Female Respondents...........................143

Appendix D - Permission to Reprint .........................................145

Appendix E - Cover Letters.............................................152

Appendix F - Descriptive Statistics Summary, Gender, With Endorsement.........155 


\section{Dedication}

To:

My Mom and Dad, thank you for all the love any child could want. You both were and are tender souls who gave me strength and wisdom and the ability to love. Mom, you left me too soon, but you are always in my heart. Dad, you are with me now, you are one of my heroes.

Debbie and Josh, thank you for your sacrifices, your help, and your encouragement. Debbie, you have endured beyond enduring. Josh, you are God's beautiful gift, you are my other hero. 


\section{Acknowledgements}

I want to thank all the people who gave me support and help with this project. Doctor Rosier, you pushed me out of my comfort zone and made me think deeper, you made my study stronger, and for that I thank you. Dr. Goeres, you were the mediator, you saw merit in all discussion, you kept us mindful of the goal, and for that I thank you. Dr. Santin, you were my colleague before all this started, you were and still are a trusted source of knowledge, you are still my colleague, and for that I thank you. Dr. Diaz, you came on board late, you crunched all the numbers, you had the patience to explain all the numbers, you made a great committee even better, and for that I thank you.

Dr. Chapman, you were put in my path for a reason, you gave me a chance, you saw value in what I wanted to do, you only smiled and made it all doable, you told me not to worry, it would all work out, you have become not only my mentor, but my friend, now you are in my path forever, and for that I thank you.

To all my friends and family, whether you are near or 120 miles away, I thank you for the blessing of being in my life. You have been gentle but striking in your support of me, and for that I thank you. Know where you are, where you always are.

All of you have made this possible, and for that I thank you. 


\section{List of Tables}

Table 1. Responsibilities of Education Agencies.....................................15

Table 2. Priority Ranking of Special Education Administration Training Needs..........25

Table 3. Responsibilities of Principal...........................................37

Table 4. Alignment of INTASC Core Principles and CEC Standard Domain Areas........42

Table 5. Skills Learned On-The-Job - All Respondents..................................70

Table 6. Skills Learned On-The-Job Male and Female Respondents..........................72

Table 7. Building a Better Education Administration Program All Respondents..............74

Table 8. Building a Better Education Administration Program All Male and Female

Respondents..................................................76

Table 9. Special Education Director Preparation All Respondents with Administration

Endorsement...................................................80

Table 10. Special Education Director Preparation Male and Female Respondents with

Administrative Endorsement.......................................82

Table 11. Skills Learned On-The-Job All Respondents with Administrative

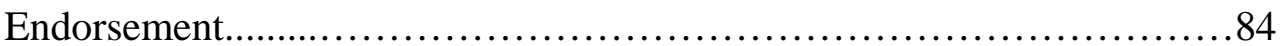

Table 12. Skills Learned On-The-Job Male and Female Respondents with

Administrative Endorsement.........................................86

Table 13. Building a Better Education Administration Program All Respondents with

Administrative Endorsement..........................................88

Table 14. Building a Better Education Administration Program Male and Female

Respondents with Administration Endorsement...........................90 
Table 15. Skills Learned On-The-Job All Respondents without Administrative Endorsement.

Table 16. Skills Learned On-The-Job Male and Female Respondents without Administrative Endorsement...............................................94

Table 17. Building a Better Education Administration Program All Respondents without Administrative Endorsement.......................................96

Table 18. Building a Better Education Administration Program Male and Female Respondents without Administration Endorsement...........................98 


\section{List of Figures}

Figure 1. Discourses in Special Education............................................34

Figure 2. The Star Model of Special Education Training $\ldots \ldots \ldots \ldots \ldots \ldots \ldots \ldots \ldots \ldots \ldots . . . .40$

Figure 3. Timetable.......................................................49 


\section{CHAPTER 1}

Introduction to the Study:

Context of the Problem

Strauss and Corbin (1998) note that personal insight sparks more insight. Both the personal and professional experiences of the researcher can bring a sensitivity of the question to a study by providing a comparative base. It is this sensitivity that assists the comparison of the data with the knowledge base of the researcher. Yin (1994) stresses the importance of the study being composed in a manner that will engage, entice and seduce the reader. Krathwohl (1998) notes in quantitative research, there is an objective reality out there to be discovered. Strauss and Corbin (1998) wrote that qualitative methods can be "used to obtain the intricate details about the phenomena such as feelings, thought processes, and emotions that are difficult to extract or learn about through more conventional research methods” (p. 11). A combining of the two research styles complement one another in addressing the research question thoroughly.

It is with a blending of the two approaches in mind, that this researcher used that personal insight and sensitivity to the question in presenting the introduction section of chapter 1 as a first person narrative. This method of presentation afforded the writer the opportunity to draw on personal insight related to the purpose and the study question in communicating with his respective audience. Claerbout (1991) indicated the writer needs to make a new contribution to existing knowledge. Writing in the first person lets the reader know where common knowledge runs out and the new contribution of the writer's ideas begins. This communication style proved effective in dissertations (Bays, 2001) as it allows the reader to use his or her eyes to listen to the 
personal background setting for presenting the succeeding sections of chapter 1 . The setting then offered a natural conduit for the transition into the subsequent chapters of the study.

\section{Introduction}

On July 1, 1996, I took over as the director of a special education program in the mountains of Appalachia. My preparation for my current position as a special education administrator could at best be termed as on-the-job training.

My undergraduate degree was in social studies which I taught for two and a half years. My master's was in physical education, which served as a door to allow me to coach basketball at the college level for ten years in New York and West Virginia. Over time I obtained endorsements in special education from the West Virginia Department of Education for the areas of behavior disorders, learning disabilities, and mental retardation.

Swan (1998) noted a nationwide shortage of educational administrators. This was evident in West Virginia when during the 1990s an administrative endorsement could be obtained for a minimal amount of money. That endorsement allowed one to be a principal at the elementary, secondary, and vocational school levels as well as a superintendent of a county public school system.

I remember going to the state capitol that first summer for a state special education meeting for new special education directors. The State Superintendent of Schools' greeting was a welcome to the hardest job in the field of public education, even harder than that of superintendent and a reminder that we need to be more careful with what we wish for.

The first meeting of regional special education directors was somewhat intimidating. I 
left that meeting with a thunderous headache and the stark realization that I did not know one thing about my job.

That scenario is more common than most would care to admit, but for many of my fellow special education directors it is reality. We come from various educational backgrounds. In spite of a lack of formal training, we have managed to survive, relying on many sources of help in identifying and implementing our own unique styles of leadership to serve the students with disabilities for whom we are advocates, their teachers, and our supervisors. Those sources include talking with fellow special education directors, calling predecessors, reading professional leadership literature, attending State Office of Special Education in-services, workshops, and seminars, and experimenting with trial and error situations on the job.

Those experiences led me to question if our preparation as administrators of special education programs was appropriate. This lack of formal training was the focus of my study.

Purpose and Reason for the Study

The proper supervision of educational programs is a long-standing function of public education in the United States (Glanz, 1998). The proper supervision of special education programs within the specter of public education was the overall guiding purpose of this study. The ultimate goal is to provide the supervision for optimal educational opportunities to students with disabilities. One aspect of this type of supervision is making sure a highly qualified staff is serving these students and their families (No Child Left Behind, 2002; Individuals with Disabilities Education Act, 2004). This needs to be done in an environment that ensures the safety and well-being of the students under the supervision of the special education director. 
That supervision can be seen from the perspective of promoting research-based instruction through sustained programs for professional development. This professional development focuses on educators in order to enhance overall student achievement. Nowhere is that aspect of supervision more publicly advanced than through the No Child Left Behind legislation signed by President George W. Bush on January 8, 2002 and now with the New IDEA legislation, also signed by President George W. Bush on December 3, 2004.

Special education is an outgrowth of the Education for All Handicapped Children Act (EAHCA), Public Law 94-142 (PL 94-142), passed in 1975, and its subsequent reauthorizations and amendments. All these awarded students with disabilities the opportunity to gain access to, and benefit from, an education delivered through and within the public education system. From an administrative perspective, the accountability base of that legislation was one of compliance in meeting timeline requirements. The focus was the procedural safeguard aspects of meeting the needs of the individual student outlined in his or her Individualized Education Program (IEP). PL 94-142 was further advanced in its scope with The Individuals with Disabilities Education Act Amendments of 1997 (IDEA), which provided a free appropriate public education to properly identified students, delineated through special education and related services (§ 601 (d)(1)(A)).

With IDEA, public school systems and administrators are now faced with the provision of instruction and services that are specially designed to meet those students' unique educational needs. The special education administrator is accountable for the provision of services designed to meet identified needs that could include the cognitive, physical, social, and/or emotional areas. These services are to be provided through direct special education services and related services 
by diverse, specially trained providers that could include the following, (a) special education teachers, (b) speech pathologists, (c) general education teachers, (d) paraprofessionals, (e) psychologists, (f) occupational therapists, and (g) physical therapists. They may be employed by the local school system or contracted from a host of providers outside the public school system. The environment for the delivery of those services follows a cascade from the general education classroom to resource rooms, self-contained classrooms, alternative classrooms, alternative schools, hospitals, and homes.

No Child Left Behind legislation calls for greater accountability. Recent reforms call for site-based management and the inclusion of students with disabilities in the regular education environment supported with supplementary aids and services. The reason for the study becomes apparent; these demands on the special education administrator's base of information will only continue to increase. The knowledge base needs to be identified.

\section{The Research Question}

I was overwhelmed by the changing knowledge base and a lack of formal training for this position. The research question grows out of my experiences with the skills required in order for practitioners to be successful directors of special education at the public school level in West Virginia. The growing knowledge demanded of special education administration requires the researcher's lens to be focused on the following question:

1. What is the knowledge base special education directors feel they need to know in the field of special education administration? 


\section{Overview of the Dissertation}

The following is be a brief layout of the dissertation. Data will be provided through a survey, selective sampling, follow-up personal questionnaires and interviews with individuals currently involved in the supervision of special education programs. Through the data collection and analysis, the reader gains an insight for the concern of the director's knowledge base and whether that knowledge was gained during their preparation program or from experience gained on the job.

Chapter 1 of my dissertation includes a background for the content, an introduction of the topic, the purpose and reason for the study, a statement of the problem, and the research questions. Chapter 2 is a review of related literature. It describes the problem in a current frame of reference as well as describing historical perspectives of administration for special education programs. It serves to tie the statement of purpose and reason, the problem, and the research questions presented in Chapter one to the rest of the study.

Chapter 3 presents the methodology used in the study. This includes an explanation of the design of the study, the survey or sampling procedures, the data collection and related safeguard management procedures, and the data analysis procedures. Chapter 4 translates the data gathered in Chapter 3 into the findings of the study. It also describes the background and characteristics of the participating special education administrators. Chapter 5 provides additional discussion of the findings as conclusions drawn from the study, as well as providing implications for practitioners and future research. 


\section{Limitations of the Study}

Limitations of this study, as are apparent with any investigation, need to be considered before the reader should attempt generalizing the results. This research was conducted to glean an understanding of the perceptions current special education administrators held related to the knowledge base needed for their position. Formal training and on the job experiences were explored. The subjects of the study were from current directors of special education in West Virginia. The limitations are listed and discussed below.

1. In part, the study relies on self-report data provided by the respondents who completed a survey. While this type of data does yield greater statistical data, it is not as accurate as observational data. This researcher recognizes that, while self-report survey data is an appropriate part of mixed methodology, the perceptions of the respondents could be influenced by confounding factors. A major consideration related to an individual's perceptions in this study, is the time lapse factor between their educational preparation and the completion date of the survey.

2. While the data from the quantitative aspects of a mixed method can be somewhat generalized, when the intent of a study is to gain an understanding of individualized outcomes, care in qualitative research has to be taken. Purposeful (selective) sampling cannot be generalized to an entire population, yet the strategy will increase the credibility of the results (Patton, 2002). The findings of this exploratory study are not necessarily generalizable to practitioners in other states. 
The conclusions drawn from the research may illuminate the group being studied, yet may not be applicable to other groups and settings. Any transferability of the findings of this study to other settings will be left to the discretion of the individual reader. Limitations are inherent in mixed method studies using selective sampling, yet the factors related to emergent findings can outweigh those limitations (Patton, 2002).

3. In response to the quantitative questions in the study, respondents were asked to respond by choosing from an ordinal set of ranges. Ordinal responses often do not provide as much information as do absolute value responses regarding variance in scores.

4. When only one observer records the descriptions that comprise the data, there will always be questions related to the observer's expertise, consistency, and bias. Researchers are prone to errors of subjectivity and imprecision in the collecting and analyzing qualitative data. Drawing conclusions from data analysis is easily affected by investigator bias. Questions arise concerning the validity of the findings. 


\section{CHAPTER 2}

Review of Related Literature:

Major Factors

Swan (1998) tells us there is a reported nationwide shortage of administrators in general, but this does not address the situation related to special education administrators. At the state level, the concern is seen in the turnover rate of state directors. The main factors contributing to that turnover are directly related to politics and burnout (Schnaiberg, 1995). He further reports that turnover is seen in direct relationship to an increase in violations in special education law and a lack of state level stability in leadership.

Aside from the shortage of qualified administrators at the state directors' level, several factors were considered associated with the shortage of special education administrators in general. Several researchers pointed to the high cost associated with maintaining quality programs (Burrello, Lashley, \& Beatty, 2001; Carta \& Greenwood, 1997; Connor, 1961; Crockett, Sughrue, \& Berlin, 2003, Schwenn, 1995). Other researchers were ready to note higher level administrative support or the lack thereof as a barrier to potential special education administrators (Crockett, Sughrue, \& Berlin, 2003; Hooper, Pankake, \& Schroth ,1999; Monteith, 2000; Pazey, 1993). Still other sources noted the bureaucracy associated with the volumes of paperwork and related legal concerns as deterrents for entering these administrative positions (Individuals with Disabilities Education Act Amendments of 1997; Lipsky \& Gartner, 1996; Schnaiberg, 1995; Tomlison, 1996).

A nationwide study by Arick and Krug (1993) revealed a shortage in $10 \%$ of the districts 
related to having qualified personnel in special education administrative positions. They further projected that in the following four years nearly half of the responding school districts would be experiencing a similar shortage. According to the Center on Personnel Studies in Special Education (COPSSE) (2004), if current trends continue, more and more positions for special education administrators will remain open due to a lack of qualified candidates to fill them. The Center estimates that more than twenty percent of current special education administrators are not fully certified. The number of graduates of administration programs with advanced degrees, master's or doctorate, specializing in special education is less than one percent (COPSSE, 2004).

The issues presented here related to the nationwide shortage of educational administrators in general, and more specifically to this researcher's questions, point even more to the concern for the current level of preparation of those entering administrative positions for special education programs. In today's high stakes accountability educational climate, the expenditure of capital resources related to programs and services for students with disabilities necessary to address that accountability cannot be entrusted to those who are not properly prepared for the challenge. Perhaps the accountability issues alone are enough for those in positions to train and those in positions to hire to realize the problems could be even more serious without properly prepared special education administrators at the helm of such programs.

\section{Evolution of Special Education}

As Sage (1981) wrote, "The practice of administration of special education has undergone pronounced evolution and can be expected to continue to evolve...” (p.321). Important now is to provide a snapshot of the evolution of special education in general to offer a perspective of what 
faces special education administrators. Zigmond (1997) noted that children with disabilities were initially considered to be a burden to the regular education teacher and an impediment to the learning of their non-disabled peers. Burrello, Lashley, and Beatty (2001) termed this stage of the evolution as the continuum of services discourse. The design of the special education program was separate classes with a protective and nurturing atmosphere.

Starting in the 1960s, instructional and educational benefits were taken into consideration (Zigmond, 1997; Burrello, Lashley, \& Beatty, 2001). While inclusive practices were gaining wider acceptance and implementation, the arena for the delivery of the instruction was still outside the general education classroom.

Effective instructional strategies became a concern for all educators in the 1980s. There was a shift in the complexion of the classroom, with diverse cultures and languages becoming more apparent. Education started to follow business in that it moved toward a more decentralized oversight for management of programs to the building level (Goor, 1995). Educating special education students in the mainstream gained emphasis. With the mainstream emphasis came a need for regular education and special education teachers to communicate and cooperate (Simpson \& Myles, 1993). Moreover, compliance with statute was still a major concern for administrators.

By 2002 and No Child Left Behind, accountability for the learning of all students had become the major focus not only for special education administrators, but also for all administrators and educators involved with the delivery of instruction to all students. An era of unified school systems has been emerging, again with administrative practices viewed in terms of 
learning for all students (Burrello, Lashley, \& Beatty, 2001).

This evolution of special education fostered by public mandates and legislation has moved all of education further down the road in school reform to a confluence resulting in more inclusive schools. Once again the resulting issue stressed the need for properly trained and knowledgeable administrators in the field.

\section{Legislative and Legal History}

Another important aspect in understanding the evolution of the special education director's role in the oversight of programs for students with disabilities is the legislative perspective. Martin (2001) noted the administration of educational programs for students with disabilities can be traced to the Fourteenth Amendment in that every child is afforded the right to an education under its equal protection clause. Yet even with that protection, states had been historically remiss in their efforts to provide education for students with disabilities. Alexander and Alexander (1984) noted that even into the mid-to-late 1960s, a majority of states did not have uniform standards providing for the education of handicapped children. They further pointed out that many states did not provide funding for education of the handicapped.

During the 1950s and 1960s, the federal government had growing support from parents and advocates (Alexander \& Alexander, 1992). During the 1970s, landmark court decisions including Pennsylvania Association for Retarded Citizens (PARC) v. Commonwealth (1971) and Mills v. Board of Education of the District of Columbia (1972), established the responsibility of states and localities to educate children with disabilities. The $P A R C$ case put forth the concept that the education and training of the child had to be appropriate to the child's capacity. In that 
context, it was presumed the regular education classroom was more appropriate to meeting the child's capacity than was a placement in a special classroom. In Mills, the courts allowed for a comprehensive plan that laid the groundwork for future legislation in the area of handicapped children's rights to an education. The plan provided for a free appropriate education, an Individualized Education Plan (IEP), and due process procedures (Alexander \& Alexander, 1984; Alexander \& Alexander, 1992; Martin, 2001; Turnbull, 1986). Both cases stressed procedural aspects of program supervision for the special education administrator to address.

In 1970, IDEA made its first appearance in the form of the Education of the Handicapped Act (EHA). The focus was to establish minimum requirements for states to meet in order to receive federal funding in their efforts to provide free appropriate public education to students with disabilities (Students with Disabilities, 2004).

No other current legislation has changed the roles and responsibilities of all educators concerned with the learning of exceptional learners more than the Education for All Handicapped Children Act (EAHCA), Public Law 94-142 (PL 94-142), passed in 1975. It became a mainstay for students with disabilities for fifteen years. And with that, the greatest impact has been to those charged with the administration of special education programs (Prillaman and Richardson, 1985). Its 1990 amendments, Public Law 101-476 (PL 101-476), which changed the name to the Individuals with Disabilities Education Act (IDEA), again addressed the procedural aspects of program supervision for administrators (History of the IDEA Retrieved 2004).

Another reauthorization to IDEA came in the form of the Individuals with Disabilities 
Education Act Amendments of 1997. This version was highlighted by the need for more parental involvement, greater access to the general curriculum, and its attempts to reduce the overall paperwork associated with the IEP process.

The most current reauthorization to IDEA, Individuals with Disabilities Education Improvement Act (H. R. 1350) (Public Law 108-446), the new IDEA was signed into law on December $3^{\text {rd }}$, 2004, by President George W. Bush. Important changes in IDEA give schools more latitude in matters of school safety and discipline, greater flexibility and control of federal allocations, a release from compliance with some regulations, and a supposed reduction in the paperwork for teachers (Individuals with Disabilities Education Act, 2004).

The importance of this history is to realize that early administrators were mainly occupied with procedural compliance issues prescribed by law. Today that compliance, while not the focal issue of the past, is still a concern for special education administrators. We need to be reminded that it is a concern of importance in the director's role and that it should not be overlooked in addressing the preparation of administrators in special education.

\section{Roles of the Special Education Director}

Through that series of legislation, handicapped children benefited from the significant role of the federal government. Meyen (1995) reported that role is viewed as twofold: (a) to provide a free and appropriate education (FAPE) to students with disabilities, and (b) to provide state and local educational agencies financial support in meeting the needs of those students. Although organizational structures or levels of responsibility may vary from both state to state and within the local educational agency, Table 1 illustrates the duties typically associated with 
Table 1

Responsibilities of Education Agencies

\begin{tabular}{|c|c|}
\hline Agency & Function \\
\hline $\begin{array}{l}\text { U.S. Department of Education } \\
\text { Office of Special Education and } \\
\text { Rehabilitative Services (OSERS) }\end{array}$ & Serves as a resource to Congress in legislation. \\
\hline Office of Special Education (OSE) & $\begin{array}{l}\text { Enforces implementation of federal laws. } \\
\text { Provides leadership in coordinating national responses toward meeting } \\
\text { the needs of exceptional children and youth. } \\
\text { Administers federal funds to state and local education agencies. } \\
\text { Provides leadership in stimulating research and personnel training. }\end{array}$ \\
\hline State education agencies (SEAs) & $\begin{array}{l}\text { Establish rules and regulations for the approval of local educational } \\
\text { programs serving exceptional children and youth. } \\
\text { Serve as a resource to the state legislature on matters relating to exceptional } \\
\text { children and youth. } \\
\text { Provide leadership in developing and implementing comprehensive } \\
\text { statewide plans to ensure equal opportunity for exceptional students. } \\
\text { Serve in a liaison role with other state agencies in coordinating the services } \\
\text { to exceptional youth and their families. } \\
\text { Monitor compliance of local school districts in meeting state and federal } \\
\text { requirements. } \\
\text { Provide leadership to local districts in development of inservice training. } \\
\text { Maintain data on numbers of exceptional children served and identified } \\
\text { and on program expenditures. }\end{array}$ \\
\hline Local education agencies (LEAs) & $\begin{array}{l}\text { Provide appropriate educational programs and services for all exceptional } \\
\text { children and youth. } \\
\text { Implement programs in compliance with state and federal regulations. } \\
\text { Conduct inservice training to assure that all educational personnel are } \\
\text { effective in meeting the needs of exceptional students. } \\
\text { Maintain due process procedures. } \\
\text { Serve as liaison with community agencies in coordinating programs for } \\
\text { exceptional children and youth. } \\
\text { Operate long-range comprehensive planning programs to assure quality } \\
\text { programs for exceptional children and youth. }\end{array}$ \\
\hline Intermediate education units (IEUs) & $\begin{array}{l}\text { May provide direct services to exceptional children and youth. } \\
\text { Frequently provide support services to LEAs. } \\
\text { Comply with state and federal regulations governing the education of } \\
\text { exceptional children and youth. } \\
\text { Often contract with LEAs to provide transportation for exceptional children } \\
\text { and youth. } \\
\text { Generally operate inservice training programs as part of an instructional } \\
\text { materials center. }\end{array}$ \\
\hline
\end{tabular}


Table 1 Continued

(An IEU is an organizational structure between the LEA and the SEA. In several states IEUs are set up by county boundaries. Other states ignore county lines and allow adjoining districts to organize as IEUs. IEUs vary in the services they provide. Some have taxing powers; others obtain funds from SEAs and by contracting with LEAs).

Note. From Special education and student disability: An introduction. Traditional, emerging, and alternative perspectives (p.79), by E. L. Meyen and T. M. Skrtic, 1995, Denver, CO: Love. Copyright 1995 by Love. Reprinted with permission. 
each level in providing services to students with disabilities (Meyen, 1995). It is important here to understand that as the federal government defines its role, it also defines the state and local education agencies’ roles.

Once the roles of the state and local education agencies are defined, the roles and the responsibilities of the director of special education become clearer. The Council for Exceptional Children (1993) provided its own twofold clarification of "who" and "what" for those in charge of administering special education programs within the local school district: (a) who is responsible in the decision making process, and (b) what procedures need to be developed to ensure protection of the individual child's rights. The major functions commonly delegated to administrators of special education programs are as follows (CEC, 1993): (a) Establishing and maintaining effective ways of identifying children with special education needs. (b) Assessing the special needs of children to determine what kinds of special programs and services should be provided for them. (c) Planning and organizing an appropriate variety of interventions or program alternatives for children with exceptionalities. (d) Marshalling the resources needed to conduct a comprehensive program of special education. (e) Using direction, coordination, and consultation as required to guide the efforts of all those who are engaged in the special education enterprise.

(f) Conducting evaluation and research activities to reflect new emphases and to incorporate new knowledge and constantly improve special instruction and the quality of special services. (g) Involving community representatives in planning programs to ensure their understanding and support. (h) Conducting programs for staff development, such as in-service or continuing education. 
Goor (1995) further stated the special education administrator’s job is a balancing act. The administrator has to balance the needs of students and the wants of parents, with dwindling human and capital resources in providing services designed to promote individual learning and growth as prescribed by federal and state mandates. The administrator needs to be not only a compliance officer regarding legal matters, but also an astute politician, a visionary for planning. In addition to a solid understanding of fiscal matters, the administrator must possess the ability to work with parents, staff and administrators, and perhaps most of all, communicate effectively and efficiently (Goor, 1995).

More concerns evolved for special education administrators. During the 1990s concerns related to diversity became a challenge to special education administrators and their ever-changing roles.

Cultural diversity, presumably not a major point in the original passage of $I D E A$, now is regarded as presenting new challenges for testing children in their native languages, providing interpreter services for non-English speaking students, and providing teachers who can deliver the curriculum in the child's native language. Artiles and Trent (1997) agreed that a fast developing role for special education administrators is the increasing cultural diversity of students within the United States.

That challenge has continued into this century and will be a factor requiring ongoing attention. Goor (1995) noted the socioeconomic change in education is fully in focus with the fact that $24 \%$ of children nationwide live in poverty. He predicted the following for the 2000s: (a) $60 \%$ of children will live in one-parent families, usually with a female and in low income 
households; (b) more than $40 \%$ of the student population will be of minority background; and (c) over 200 languages and dialects will be spoken by that $40 \%$ minority. The role of the special education director in the oversight of programs for students with disabilities within these areas will be paramount related to accountability issues.

Hehir (1999) noted progress has been made for students with disabilities in several areas, including access to the general curriculum, educational opportunities at the postsecondary level, and greater opportunities for postsecondary employment. He was also quick to note that the roles of special education administrators must evolve to meet the challenges presented with the mentioned gains. While he sees compliance issues continuing to be critical, there are four other areas identified which the special education administrator will have to articulate: (a) knowledge of the diverse needs of students with disabilities and knowing how to translate that into practice, (b) collaboration skills, (c) building effective relationships with outside agencies to benefit students and their families, and (d) a willingness to form alliances with parents and the disability community.

There are additional concerns related to the quality of scholars, medical issues, global technology, and industry's demands for entry level workers to be better skilled in math and literacy coming out of the American public educational systems (Goor, 1995). With these concerns for the overall student population come specific changes for the special needs population and the role of the director in meeting those needs. Goor (1995) further noted a shift from emphasizing disability to valuing the individual, from providing services in isolation to integration 
Perceptions of Knowledge and Training 20

into school and community as a whole, and from pre-determining life outcomes with programs to preparing students for independent lives. Within that scope of community relations, the role of special education directors is to articulate the needs of the students in their charge. This role is essential to ensure greater acceptance of the students in their local community.

Education, like most organizations, has three essential functions regarding policy: (a) development, (b) translation, and (c) implementation (Cessna, 1995). Within that scope, the role of the special education director is seen as one of middle management. The function of translator from the middle management position offers the most potential or power to make a positive impact on the system by the director. In this position, Cessna (1995) noted the director has to be able to understand the laws and policies from above in the chain of command and then have the ability to translate to those down the chain to ensure effective and efficient programs for identified children within the parameter of those laws and policies.

Often, the tasks performed by the director of special education are not visible to the public. In this age of technology, the director must be able to adapt behind the scenes to its ever changing capabilities. Although ten years ago knowledge of technology may not necessarily have been considered an essential skill for special education administrators, today they must be prepared to use the computer to assist in administering their programs. Larson and Wheeler (1995) noted the difficulty ten years ago of predicting special educators would (a) be more prone to carpal tunnel syndrome than pencil calluses, (b) use the modem and fax machine more than the U. S. Postal Service, and (c) conduct business from their car or an airplane. They viewed technology in special education administration as assisting administrative functions, promoting communication and collaboration, and developing human resources. 
Management information systems such as the West Virginia Education Information System (WVEIS) expand the director's role in accountability and afford the administrator almost immediate access to comprehensive and accurate data. In the forward to a 2003 West Virginia Department of Education publication, Dr. David Stewart, State Superintendent of Schools, noted WVEIS as the first step in accountability when examining results of student progress related to No Child Left Behind school improvement and for the 1997 amendments to the Individuals with Disabilities Education Act in the continuous improvement process (Office of Special Education, West Virginia Department of Education, 2003).

Other hidden roles of the director are related to recruitment and hiring of new personnel and the legal rights of employees with disabilities. Special education directors may or may not be directly involved in the recruitment or the actual hiring of new personnel, but definitely need to be involved in activities to train, retain and motivate personnel. The director's role now becomes that of being a human resource manager (Goor, 1995). Under No Child Left Behind, programs of staff development become crucial as districts seek highly qualified personnel to deliver education programs. These staff development programs not only need to be scientifically research-based, but they also need to promote in each staff member ownership of learning and authentic personal engagement (Lee, 1993).

Inherent in the administrative role for special education directors is an awareness of the disabilities of the students; however, the legal rights of employees with disabilities are a factor not often considered by those same administrators. Griffith and Cooper (2002) indicated attitudes toward the hiring of individuals with disabilities have greatly changed since the passage 
of the Americans with Disabilities Act (1990). Administrators charged with personnel duties must be knowledgeable in accommodating employees with disabilities and also need to avoid discriminating against potential employees with disabilities (Shaw, 1996; Dayton \& Arnau, 1999).

From possessing the ability to balance student needs and resources, to understanding the far reaching demands related to cultural diversity, to being a translator and articulator of federal mandates to implement effective programs for students with disabilities, the role of the special education director is ever expanding. These multidimensional roles only punctuate the need to provide the appropriate preparation for the special education director.

\section{What Practitioners Are Saying}

At the heart of the concern for what practitioners are saying is the recognized dearth of information related to the questions of this study. Finkenbinder (1981) noted this lack of literature in a brief history of related studies and offers that while the field of special education was growing, the literature specifically corresponding to the needed skills and preparation of administrators was at best sporadic. Swan (1998) also noted the limited research literature in the area. He notes most research tends to focus on the supervision of general education, that few research journals focus on special education leadership, and that there are numerous challenges encountered in conducting research in the area. Boscardin and Lashley (2003) noted that there is limited research in the area of supervision of special education programs. They theorize that, in part, this is related to a lack of a wide acceptance of national standards for certification. Interviews with other noted authorities revealed similar results and concerns (Lashley, Boyer, 
Crockett, Biklen personal phone contact).

Despite the limited research, studies were found that indicate what practitioners are saying related to the skills and knowledge they feel is essential to be effective in their positions as administrators of special education programs. In a 1974 study, Jones and Wilkerson (1975) found that areas of concern for administrators included law, transportation, staff development, and the total educational process. Of note is that during this time period, the authors pointed out a shift in separate programs designed specifically for special education administrators to programs designed for general education administration. Those interested in administrating special education programs were now looking at majoring in school administration with a minor in special education (Jones and Wilkerson, 1975).

Swan (1998) followed studies of practitioners by Harris and King (1975), Rockert (1982), Zadnik (1985), Burrello and Zadnik (1986), CASE (1993) and found common factors critical for successful performance. Their findings showed consistency in the factors critical for successful performance: (a) knowledge of curriculum, (b) staffing and organization, (c) knowledge of services, (d) staff development, and (e) communications skills. Conspicuous in their absence were the legal and compliance roles related to the position. In other research, Monteith (2000) did note not only are the former issues covered, but the latter are also addressed in a report from the North Carolina Comprehensive System of Personnel Development Report (1991-1995).

One of the more involved and current studies related to the needs of practitioners was conducted by Arick and Krug (1995). The researchers received responses from 1,468 special education directors to a four part survey concerning (a) personnel needs, (b) quality of 
preparation, (c) training needs, and (d) administrative policies/practices for mainstreaming students with disabilities. Focusing on part “c” of the survey, training needs (Table 2), the top three areas identified were (a) collaboration of special and general education staff and others, (b) evaluation of program effectiveness and quality, and (c) adaptation of curricula and instruction for students with disabilities.

A study of British special education administrators conducted by Powers, Rayner, and Gunter (2001) concerned areas of professional development practitioners felt were most instrumental in contributing to their skills and knowledge base. The study revealed that both females and males felt development in leadership and management areas were priorities. These areas were viewed as people skills rather than organizational or inherent skills. An interesting related note to that finding is that the responders felt developing professional expertise was of greater interest than advancing their career development (Powers, Rayner, and Gunter, 2001).

Wigle, Stanley, and Wilcox (2002) conducted a study of the competencies of special education directors on a set of 35 skills identified by the Council of Exceptional Children (CEC) as important for professionals working in special education. The responses of the directors were then compared to responses of special education teachers and general education administrators. While the study did not directly address the research questions, it pointed out that directors do see themselves as more skilled than adequate and far more adequate than inadequate in the skills and related knowledge base of the CEC standards than do the special educators and general education administrators.

In a 2003 article, Crockett, Sughrue, and Berlin (2003) explained a research project 
Table 2

Priority Ranking of Special Education Administrative Training Needs

Training Needs

Rank

$\underline{\text { Special Education }}$

Collaboration of special and general education and others 1

Evaluation of program effectiveness and quality 2

Adaptation of curricula and instruction for students 3

Promotion of appropriate student behavior 4

Effective service delivery models in special education 5

Promotion of integration/mainstreaming 6

$\begin{array}{ll}\text { Education for students with severe disabilities } & 7\end{array}$

Special education funding and budgeting $\quad 8$

Collection and management of data to meet legal requirements $\quad 9$

$\begin{array}{ll}\text { Federal and state law requirements } & 10\end{array}$

Organization and management of staff and volunteers 11

$\begin{array}{ll}\text { Evaluation of professional staff } & 12\end{array}$

Pre-referral intervention policies and strategies $\quad 13$

$\begin{array}{ll}\text { Education of students with mild disabilities } & 14\end{array}$

Placements in the least restrictive environments $\quad 15$

IEP development 16

$\begin{array}{ll}\text { Referral and evaluation of students } & 17\end{array}$

Note. From Special Education Administrators in the United States: Perceptions on Policy and

Personnel Issues, by J. R. Arick and D. A. Krug, 1993, The Journal of Special Education, 27(3)

p. 354. Copyright 1993 by The Journal of Special Education. Adapted and printed with permission. 
conducted with key players at the juncture of special and general education in the provision of special education services to students with disabilities. Nine special education directors were included in the study. Their responses yielded the areas of legal issues, support from superiors, and open communication and collaboration as key in their ability to implement proper programs and services. This study further illuminated the need for preparation programs to address concerns in the areas of ethical considerations, legal matters, instructional information, and relational strategies (Crockett, Sughrue, Berlin, 2003).

An underlying need expressed by administrators of special education is the support (or lack of it) from their superintendents, especially with implementing changes to include students with disabilities in regular education programs. Hooper, Pankake, Schroth (1999) noted that where the superintendent is active, visible, and displays a genuine concern, the staff will likely follow. If special education administrators are to implement changes that call for collaborative efforts rather than authoritarian decisions, team building rather than top-down edicts, the superintendent has to be involved. Pazey (1993) pointed out that the superintendent's attitude toward change is key to shaping the collaborative efforts of regular and special education teachers.

Along with the consideration of support from the superintendent, practitioners indicated the need to effectively articulate the understanding of Least Restrictive Environment (LRE) and the meaning of environment to the building level administrator. Kauffman and Hallahan (1997) pointed out a misleading basic assumption related to full inclusion as being the LRE. Part B of the Individuals with Disabilities Education Act (IDEA) (1990) affords certain substantive and 
procedural rights to students with disabilities, one being that education is to be provided, to the maximum extent possible, in a setting with non-disabled students (Huefner, 1997). This concept is referred to as LRE. Consideration has to be given to the special education class being inherently more restrictive than the regular education classroom (Kauffman and Hallahan, 1997):

To make an environment least restrictive of some things---academic learning or socialization, for example---other things may need to be made more restrictive, such as the tasks presented, the responses demanded, the consequences provided, and so on. In fact, the restrictions placed on antecedents, behaviors, and consequences are the very stuff of education. What IDEA envisions is the least restriction of the education environment "that will produce the desired educational outcomes for individual students.” Restrictions are necessary to produce outcomes, and the same restrictions will not produce the same outcomes for all students. Futhermore, "a single environment cannot contain all manner of restrictions, for no environment is infinitely flexible.” (p. 327)

Within the limited research available related to what practitioners indicated as needed skills for successfully fulfilling their assigned duties, major themes of law, staff development, and communication skills were seen throughout the studies. Accountability for student achievement was also seen as an emerging concern. Once the needed skills and knowledge base has been identified within limits, the nexus to the preparation of the special education administrator becomes an issue.

Preparation of Special Education Administrators Murphy and Forsyth (1999) acknowledged that knowledge and skill gained from personal 
experiences, as well as being passed on by organizations or codes, make up human endeavor. According to them, "The human endeavor under discussion here is the organization, maintenance, and improvement of educational enterprises-the profession of school administration” (p. 258).

The organization for training in school administration traditionally had been programs delivered through the system of institutions of higher education. Murphy and Forsyth (1999) further pointed out that from inception, control of those programs has been in the hands of former school administrators returning to higher education teaching. New students in the field were then subjected to learning a curriculum from the experiences of the administrator turned teacher, one devoid of technical and practice knowledge or field experiences related to school administration (Murphy and Forsyth, 1999). The preparation for special education administration had to endure a similar fate.

The historical preparation and certification of special education administrators falls under a broad umbrella. Special education administrators were required to hold a master's degree in special education, with an endorsement in one of the areas of exceptionality, and either hold or have additional hours toward a general education administration degree (Connor, 1961; Connor, 1996; Swan, 1998). The focus of the position then was centered on a need to interpret special education law and compliance issues.

The above focus is perhaps limited in addressing professional competence. Harris (1993) stressed that the education of administrators should be organized around the "problems of practice.” The emphasis was a shift from a university-generated curriculum to one that is 
inductive, one evolved around the actual work of school administrators, one of internships in the field (Murphy \& Forsyth, 1999).

All this points to the conclusion that as special education evolved, so did the need for the leadership and knowledge base of those administering special programs to evolve. Early reviews of the area provide a background for current concerns. An early examination of the areas of concern for prospective special education administrators by Connor (1961) identified seven areas: (a) authority, (b) planning, (c) organization and staff, (d) decision making and problem solving, (e) communication, (f) coordination, and (g) evaluation. Jones and Wilkerson (1975) in reviewing another study (Connor, 1966) determined the needed knowledge and skills associated with those tasks were in the areas of finance, organizational techniques, decision-making, power structure analysis, leadership qualities, political activities, selection of personnel, and community relations. Wilkerson (1975) found the tasks associated with being a director of special education to be administrative and decision-making in nature (1975). In reviewing state certification practices, Forgnone and Collings (1975) found similar needs and added school law as it relates to students with disabilities.

Goor (1995) pointed out that during the 1960s special education programs were typically managed by regular education teachers or principals who had the required administration endorsement. In most cases their primary responsibility was to oversee regular education programs first and then to tend to the special needs duties. Their understanding and knowledge of special education was from on-the-job experiences (Goor, 1995).

With the passage of the Education for All Handicapped Children Act in 1975, school 
systems began to realize that the enormity and complexity of the requirements related to implementing the law necessitated full time positions (Goor, 1995). Again, the positions were usually staffed by regular educators who learned to follow federal guidelines and state regulations related to serving exceptional children.

This situation is further magnified in that states vary widely in how they endorse or certify special education administrators (Prillaman and Richardson, 1985; Whitworth and Hatley, 1979). West Virginia is a case in point. The training of special education administrators has been narrow and dictated by state certification requirements. Prillaman and Richardson (1985) noted in West Virginia the State Board of Education approved certification-endorsement requirements for special education administrators. Today, for all practical purposes, those standards are ignored; it is left to the local school district to determine the qualifications they require in their position postings (C. Lashley, personal communication, November 10, 2004).

The body of knowledge for a person to become certified is a focus for the consideration of alternative ways to address the lack of special education administrators. States are considering a base program for principals as the gateway for other endorsements for administration, including special education. For example, the Interstate School Leaders Licensure Consortium (ISLCC) has formulated standards, yet those standards do not address special populations (Bateman, D., Boscardin, M. L., Crockett, J. B., Di Paola, M., Lashley, C., McLeskey, J., Thornton, H. Feb. 2003. Research Planning Session: Administration in Special Education).

Swan (1998) stated that special education occurs in a multidimensional arena, making its supervision a challenge. The need to look at alternative approaches to provide training for 
administrators as well as teachers is crucial in light of the concern that the number of special education administrators is limited. Often the position is coupled with concurrent teaching or building level administration or other specialized programs. Special education administrators need to be aware not only of cutting edge instructional efforts, but also of the same concerns facing building level administrators . The need to participate in continuing learning sessions and to share information requires both opportunity and time for all administrators to be properly versed in these challenges (Swan, 1998).

The availability of preparation programs and their course offerings are two important factors to consider in analyzing the preparation of special education administrators (Boscardin \& Lashley, 2003). These authors reported a recent review they conducted from the National Clearinghouse for Professions in Special Education (NCPSE) database that yielded information from 27 institutions that had advanced training for special education administration.

The findings of Boscardin's and Lashley’s (2003) review revealed six programs within the departments of educational administration, 19 in special education departments, and two with joint programs. The trend seems to indicate a shift toward offering courses through general administration programs rather than through specifically designed special education administration programs. This trend is seen in response to the emphasis of more inclusive schools (D. Biklen, personal communication, September 28, 2004).

The preparation of those in charge of the administration special education programs had to endure growing pains similar to those in charge of the administration of general education programs. Although specific areas of knowledge were identified as needed in preparation 
programs and specifically designed programs for special education programs were in place, several issues clouded the picture. State licensure, lack of national standards, properly trained preparation teaching staff at institutions of higher learning, along with other issues have led to the consideration of alternative ways to address the need for qualified special education administrators.

Change

A major aspect of No Child Left Behind ( 2002) legislation concerns the concept of accountability for all students learning. Yet that concept for educating “all” American youth is not a current or novel issue. Connor (1961), a leader in the field of special education administration, noted that in the late 1940s educational programs for exceptional learners began to show signs of expanding within programs for all students. In relationship to the expansion of such programs, administrators of those programs needed to have a base of knowledge representative of all students, students with special needs as well as their non-disabled peers, and the ability to articulate that knowledge to the public in an intelligent and truthful manner (Connor, 1961). It is also interesting to note that in 1961 he stated, "The past decade and a half have been well termed the exceptional years for exceptional children” (p.1).

Cambron-McCabe (1997) clarifies that ensuring that all children learn is one of the key purposes in educational leadership, a concept reported to be a key variable in effective schools (Goor, Schwenn, and Boyer, 1997). If we accept that, then the skills administrators need widely differ from most of today’s education administration preparation programs. The emphasis now for the administrator becomes the learning and accountability side of education (Cambron- 
McCabe, 1997). That same emphasis is seen in the 2002 legislation, No Child Left Behind. One approach to addressing the problem is to consider if educational administrators in general, and more specifically special education administrators, are organized for results. Spady (1988), although addressing the area of educational reform, pointed out that the public expects schools to be organized for results, that education will result in all students learning more and what they are learning will be what they need to be prepared for the $21^{\text {st }}$ century:

“Organizing for results” is an inherently attractive concept. It implies a deliberate attempt to plan and conduct essential activities so as to accomplish our aims successfully—in other words, purposefully doing what we set out to do. From my perspective, that means having all students learn well, not just the fastest, the brightest, or the most advantaged. Unfortunately, our educational systems, schools, and instructional programs are not organized to achieve or ensure successful results; instead, they are organized primarily for student custody and administrative convenience. (p. 4)

There are others who question the effectiveness of special education and its associated administration and leadership. Burello, Lashley, and Beatty (2001) offered an interesting evolution of special education through a "discourse" presentation (Figure 1) of its effectiveness. They offered historical (dominant), contemporary (transitional), and emergent ways through which they criticized the organizational and leadership efforts to improve the education for all students.

The terms leadership and administration are not necessarily interchangeable. Burrello, Lashley, and Beatty (2001) contended leadership is seen at the point of origin, at the school level. 
Perceptions of Knowledge and Training 34

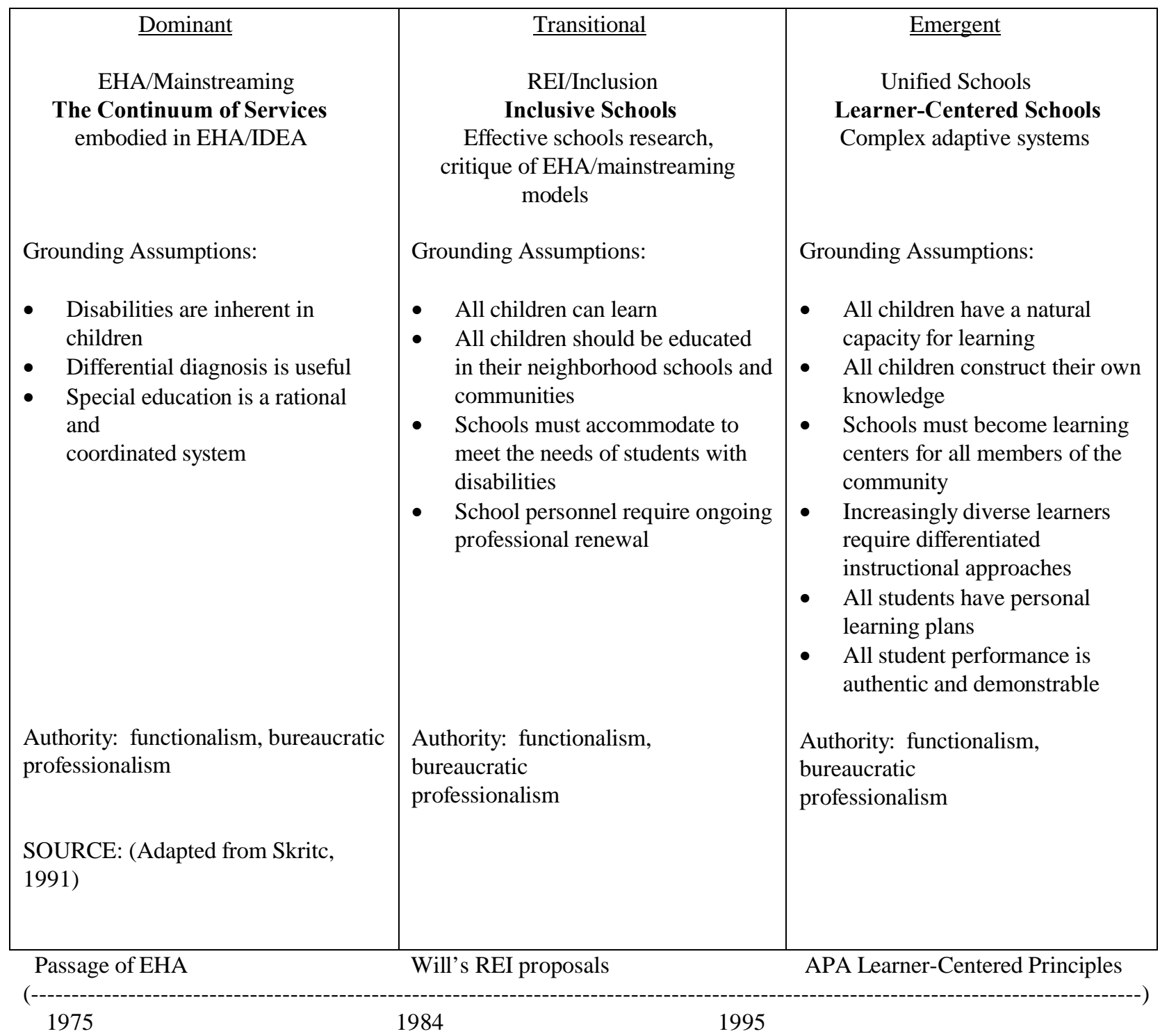

Figure 1. Discourses in Special Education: The Dominant, a continuum of services; the

Transitional, inclusive schools; the Emergent, learner-centered schools.

From Educating all students together: How school leaders create unified schools (p. 21),

by L. C. Burrello, C. Lashley, and E. E. Beatty, 2001, Thousand Oaks, CA: Corwin . Copyright

2001 by Corwin. Reproduced with permission. 
Administration was viewed as being the provider of the necessary resources for leadership to achieve results. Their work lead to more unified school systems where the administration of special education programs was viewed in its entirety, not as the specific administration of separate programs, one for students with disabilities and one for students without disabilities (Burrello, Lashley, \& Beatty, 2001). Boyer (2005) offered an interesting perspective: leadership and administration combined can be viewed as walking with one foot in the river and the other on the bank: one in the uncertainty of daily decision-making and the other grounded in providing for the overall system (L. Boyer, personal communication, January 6, 2005).

It is interesting that 22 years after Sage realized special education administration was and would be undergoing a continuing evolution, Boscardin and Lashley (2003) also noted special education administrators are now at a crossroads in the evolution of the field. Perhaps equally interesting is why we are still at that evolutionary crossroads. That crossroads, in part, is seen as the ability of the special education administrator to promote collaboration between general and special education to assure high quality educational programs delivered by highly qualified teachers are available to all students (Boscardin \& Lashley, 2003). At the crux of that crossroads is the level of preparation that special education administrators have and the knowledge base they consider essential in order to be successful in the position, an issue that is not novel to today's concerns. Connor (1961) questioned if special educators possessed the knowledge of leadership as he posed the following questions related to their administrative training:

Should they be educated under departments of general administration or in departments of special education? Do presently educated administrators and teachers of exceptional 
children have a practical knowledge of the resources and recent research in the regular administrative fields? Are preparation programs for special education administrators of a sufficiently high level of quality with student activities required in such areas as advanced course work and research (child development, psychology, sociology, as well as special education); writing and speaking; travel and visits; internships; teaching experiences; association with professional organizations and national agencies; and extended contact with varying types of programs, such as residential, state, local, city, county, preschool, elementary, secondary, deaf, blind, and mentally retarded? (p. 20-21)

Crockett (2002) provided a brief history of the growth of special education administration as a field of study before and after the passage of Education for All Handicapped Children Act (EAHCA) in 1975. She cited programs headed by Leo Connor at Columbia University, Philip R. Jones at Virginia Tech, and Daniel Sage at Syracuse University. In 1965 federal money supported programs in four universities; by 1971 the number had grown to 20. Yet as these programs grew, there were continued questions related to separate preparation programs. The main area of concern appeared to be preparing leaders who are responsive to the diversity of inclusive schools advocated in effective school reform.

In the absence of sustained literature on the skills special education directors deem necessary to be successful in their positions and with more emphasis on inclusive schools, the collaborative role of the special education administrators with the role of the principal (Table 3) becomes a focal point. The building level administrator now is the key in collaborative efforts to implement and manage all programs. Monteith (2000) notes the crucial role of principals in 
Table 3

Responsibilities of Principal

Collaborative Principal's Responsibilities As A Leader of Special Education

1. Assess the environment.

2. Reshape beliefs and attitudes.

3. Hire teachers who are open to collaborative teaming and inclusive programming.

4. Promote change and encourage innovative solutions to instructional challenges.

5. Encourage parent participation.

6. Establish teacher assistance teams.

7. Encourage interventions before or as an alternative to special education referrals.

8. Monitor assessment activities.

9. Participate in eligibility decisions.

10. Select general education teachers who provide exceptional students with an environment conducive to learning.

11. Plan for students who are not eligible.

12. Provide input for individualized education programs.

13. Support integration of students with disabilities into general education classes and activities.

14. Coordinate schedules and provide resources that facilitate the participation of student with disabilities in all school activities.

15. Include special education teachers on school wide and district wide committees.

Note. From Leadership for special education administration: A case based approach. (p.

137), by M. B. Goor, 1995, Fort Worth, TX: Harcourt Brace. Copyright 1995 by Harcourt

Brace. Reprinted with permission. 
producing effective schools. Even with that acknowledgement, most principals do not have an adequate understanding of the instructional and programmatic concerns of special needs students (Goor, Schwenn, and Boyer, 1997; Monteith, 2000; DiPaola and Walther-Thomas, 2003). Often, negative attitudes and uncertainty of roles are contributing factors related to the lack of preparation that hamper the administration of special education services at the individual school level (Goor, 1995).

Proper preparation and in-service training are essentials for success. Monteith illuminated two interesting findings in a report by Aspen (1992) to the $70^{\text {th }}$ convention of the Council for Exceptional Children that revealed more than $40 \%$ of principals never had any special education courses and despite the lack of training in the area, more than $75 \%$ of the principals had exclusive or shared responsibility over the evaluation of special education staff. Goor, Schwenn, and Boyer (1997) reflected that the principal is the leader for all programs within his or her building. So as the superintendent may set the climate within the system, DiPaola and Walther-Thomas (2003) noted the principal establishes the overall climate and influences instruction within the school. When this was translated to programs for special needs students, it was found when principals value diversity in the student population, support was provided to programs that meet individual needs. The ability of the principal to be effective in this effort is founded in a basic essential belief that all students can learn.

While that premise may appear to be a given, staff development for principals is crucial for their efforts to provide opportunities not only for students, but for all teachers and staff. This staff development is necessary to reach a greater understanding and learning new skills for living 
and working with people with diverse needs (DiPaola and Walther-Thomas, 2003). Staff development based in the use of reflection during and after the decision-making process teaches the principal a sequence of practices: (a) pausing and questioning, (b) soliciting input, (c) gathering information to clarify issues, (d) scrutinizing values, (e) examining intent, and (f) examining responses (Goor, Schwenn, and Boyer, 1997).

As this trend grows, it now seems appropriate to raise an issue in variation of Connor's concern that special education administrators lack the knowledge of leadership. Crockett (2002) questioned if general education administrators have enough knowledge regarding special education, and if they could implement special needs programs within the scope of offering programs designed to meet the needs of all students.

Here, Crockett felt special education has an opportunity to provide direction. Special education can articulate the legal requirements while advancing the core principles of meaningful education for students with disabilities to those charged with administration at the building level (Crockett, 2002). This was seen as developing responsive educational leaders and is designed to be used by administrators sequentially and/or interactively as depicted in the Star Model (Figure 2) (Crockett, 2002). The following five principles represent standards from both the Interstate School Leaders Licensure Consortium (ISLLC, 1996) and the 1998 standards from the Council for Exceptional Children related to beginning special education directors.(Crockett, Sughrue, Berlin, 2003):

1. Ethical Practice: Preparing leaders who respect others and advocate for every learner's educational benefit. 


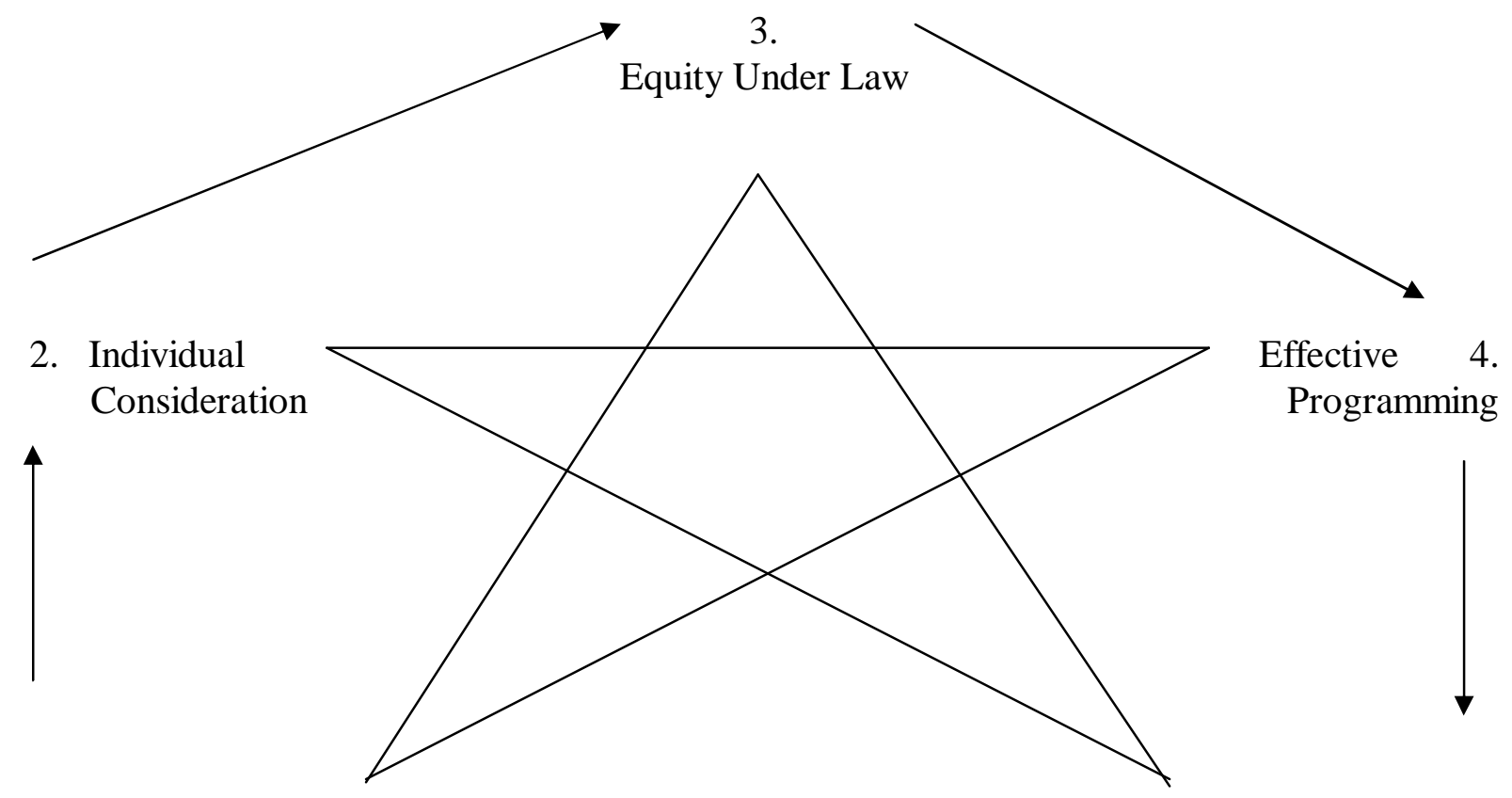

1. Ethical Practice

Productive 5.

Partnerships

Figure 2. The Star Model for Special Education Planning: The five principles of the model can be used sequentially as depicted by the solid lines or interactively as shown by the inner star for developing responsive educational leaders in the delivery of special education services by building level administrators.

From “Special Education’s Role in Preparing Responsive Leaders for Inclusive Schools,” by J. B. Crockett, 2002, Remedial and Special Education, 23, p. 164. Copyright 2002 by J. B. Crockett. Reprinted with permission. 
2. Individual Consideration: Preparing leaders who address individuality and exceptionality in learning.

3. Equity Under Law: Preparing leaders who are committed to providing equitable fiscal policies and to implementing the IDEA with integrity.

4. Effective Programming: Preparing leaders who support teachers in providing research-based programming designed to produce positive student outcomes.

5. Productive Partnerships: Preparing leaders who skillfully communicate, collaborate, and negotiate on behalf of children with disabilities and their families. (pp.7-8).

As reported by Tracy (1998), there are those education administration leaders who believe the future of administration in general will focus on group collaboration, performance, and feedback. This next generation model of supervision highlighted (a) the school is a community of life-long learners, (b) persons are capable of taking responsibility when proper resources and supports are available, (c) adult learners and children have their own unique and distinct needs, (d) total organizational environment is a factor when considering individual performance, and (e) people learn best and are motivated by collaborating with others (Tracy, 1998).

The Council for Exceptional Children (CEC) (2003) offered another concept for the next generation of administrators, an alignment of standards with the core principles of the Interstate New Teacher and Assessment and Support Consortium (Table 4). The CEC further divided the standard domains into 10 areas with individual knowledge and base skills listed for each domain 
Table 4

Alignment of INTASC Core Principles and CEC Standard Domain Areas

INTASC Core Principles

1. Content Knowledge

2. Learner Development

3. Learner Diversity

4. Instructional Strategies

5. Learning Environment

6. Communication

7. Planning for Instruction

8. Assessment

9. Reflective Practice and Professional Development

10. Community
CEC Standard Domain Areas

1. Foundations

2. Characteristics of Learners

3. Individual Differences

4. Instructional Strategies

5. Learning Environment and Social Interactions

6. Language

7. Instructional Planning

8. Assessment

9. Ethics and Professional Practices

10. Collaboration

Note: From Council for Exceptional Children (CEC). (2003). What every special educator must know: Ethics, standards, and guidelines for special educators ( $5^{\text {th }}$ ed.). Reston, VA: Author. Copyright 2003 by Council for Exceptional Children. Adapted with permission. 
competencies agencies, such as the Interstate School Leaders Licensure Consortium, use to guide both general and special education administration preparation (Boscardin, 2004).

Change is by nature a concept often met with resistance. Often the reason for the change is not communicated effectively or coherently to those who will have the responsibility for the major portion of the implementation of the change. This section has presented many of the concerns related to the ever-expanding role of the building level administrator in the oversight of the delivery of services for special needs students in their schools. While building level administrators may lack the full understanding of this role change, there is the potential for the central office director of special education to be a leader in the collaborative efforts to meet the needs of all students. Swan (1998) illuminated the issue, "Dynamic ways of collaboration among all leaders for the benefit of all students must be explored" (p. 541).

The need for specially trained administrators to direct special education programs becomes imperative. It is evident as special education continues to grow the administrative aspects become more complex. Again, with the growing concerns related to change in accountability from federal, state, and local agencies, the knowledge base required of the special education administrator is pivotal in this area of change. Boscardin (2004) aptly pointed to the knowledge base of special education administrators as it relates to change and growth: "An opportunity now exists to redefine the administrative knowledge base in a way that will address contemporary needs” (p.264). Since change is an inevitable force of organizational growth, the growth option for special education administrators related to a knowledge base needs to be presented by those who understand both the demands and the dynamic nature of the work of the 
individuals they are preparing. The nexus of the preparation offered through institutions of higher education and that knowledge base becomes more and more a matter of critical concern. 


\section{CHAPTER 3}

Methodology:

Context

Research in the area of the knowledge base directors of special education feel is needed to be successful in the position and the alignment of the content of the curriculum presented by institutions of higher education to meet that knowledge base is sparse. Although the research may be limited, it does reveal the complexity of the problem related to the need for directors to be adequately prepared. The complexity of the problem is not confined to procedural compliance issues; with new demands from both federal and state governing agencies related to No Child Left Behind and the new IDEA, today's director is faced with change in the form of accountability for students both acquiring knowledge and being able to apply that knowledge on high stakes assessments.

Change in an organization is an essential occurrence for growth. In light of the changes in the role of the director of special education, the concern over the preparation of the director is the problem addressed in this study.

\section{Purpose of the Study}

According to Marshall and Rossman (1989) research has four purposes: exploration, explanation, description, and prediction. The use of both quantitative and qualitative methods to meet one of those ends is not new. Strauss and Corbin (1998) provided the interplay of both methods can lead to useful research during all phases of the research process. Krathwohl (1998) noted quantitative methods allow for an objective reality that is out there to be discovered. He further stated in using quantitative methods, the researcher can control the events of the study 
and surmise that a particular relationship or condition exists. Qualitative methods can play an essential role in research where the relevant variables have yet to be identified. In doing qualitative research, the researcher was interested in some social phenomenon with the outcome of gaining a richer perspective of the experiences of the subjects chosen for the study (Lincoln \& Guba, 1985; Maykut \& Morehouse, 1994). In doing so, a focus of inquiry was developed to serve as a guide for the researcher (Lincoln \& Guba, 1985). With these factors the researcher could, as Marshall and Rossman (1989) revealed, logically proceed along a path "in which exploratory research can serve to identify important variables for subsequent explanatory or predictive research” (p. 15).

The purpose of this study is to develop an exploratory case study that allows for an understanding concerning the preparation of special education directors. The focus of that purpose is the knowledge base current special education directors consider necessary in order to be successful in the position.

After the concern for the safety and well being of the students under his or her auspice, the goal of providing quality special education programs becomes the focus for the special education administrator. The concern now shifts to the needed knowledge base of the director to provide those programs and whether that knowledge base has been offered through preparation programs at the graduate level.

\section{Research Question}

There is one central question that provided the direction for this study. What is the knowledge base directors of special education programs feel they need to know in the field of special education administration? 
In investigating this question, the researcher's goal takes on a focus similar to "Where are we?” "Is this where we need to be?” and “How did we get here?” It is intended that the results will be useful to current and future directors of special education programs, to higher education institutions who will be charged with preparing those leaders, and to those who will do further research in this area.

\section{Significance of the Study}

It is important to point out that previous researchers (Finkenbinder, 1981; Swan, 1998; Boscardin and Lashley, 2003) noted a lack of research literature in the area of concern. This study contributes new and needed research to the limited field. In doing so, the study provides a deeper insight for the ever changing and the multidimensional roles of directors of special education and the need for proper preparation of these leaders. Perhaps equally important, the study indicates the growing need for collaboration between regular and special education administrators to address the complexity of issues in educating all students.

This needed collaboration can serve as a springboard for institutions of higher education to refocus their efforts in providing current and flexible preparation programs. If programs specifically and solely designed for preparing future administrators in the field of special education are not provided, then the programs that are offered must have the foresight to meet the ever-changing issues related to current societal and legislative demands. From the literature reviewed and in interviewing noted professionals in the field, while there appears to be a consensus for the need for collaboration of regular and special education in preparation programs, there does not appear to be a common understanding of how this could or would happen in practice (Bays, 2001). 


\section{Researcher Bias}

Strauss and Corbin (1998) stated, "Professional experience is another potential source of sensitivity” (p. 47). That sensitivity can also be termed insight or bias and each researcher brings his or her own to each study. As the researcher I initially interacted with subjects through personal interviews and document analysis. My bias, my sensitivity surfaced through that interaction with the subjects and the initial data collected. That bias and interaction led to further data collection and continuous analysis.

It was inevitable that my personal and professional experiences played a role in this study. Having been a teacher both in the general and special education areas, the knowledge base needed for those positions was mainly acquired through formal education followed by an application of that formal training mixed with trial and error. As a coach, the knowledge base was acquired from being a player under outstanding fundamentalist teachers or coaches and then working as an assistant under other outstanding teachers or coaches. Now as an administrator, my knowledge has been acquired in part from my earlier teaching and coaching experiences, in part from trial and error, in part from my peers, in part from my predecessor, and in part from what I call instinctive understanding of the decision making process. My formal educational preparation for my current duties did not start until after I was in an administrative position.

Those experiences created a natural bias during the time frame of the study (Figure 3) and I had to control that influence during the data collection and analysis procedures. It was important to summarize at the end of each interview the major points gleaned during the session and then to ask all interviewees if they concurred. I needed to document my decisions regarding who, where, and what to investigate and why and how that data was relevant to the 


\begin{tabular}{|c|c|c|c|c|}
\hline 2004 & Week 1 & Week 2 & Week 3 & Week 4 \\
\hline $\begin{array}{c}\text { September } \\
- \\
\text { December }\end{array}$ & $\begin{array}{l}\text { Meeting with } \\
\text { committee to } \\
\text { outline research } \\
\text { questions and } \\
\text { approval to } \\
\text { proceed. }\end{array}$ & $\begin{array}{l}\text { Prospectus } \\
\text { preparation. }\end{array}$ & $\begin{array}{l}\text { Prospectus } \\
\text { preparation. }\end{array}$ & $\begin{array}{l}\text { Prospectus } \\
\text { preparation. }\end{array}$ \\
\hline 2005 & Week 1 & Week 2 & Week 3 & Week 4 \\
\hline $\begin{array}{c}\text { January } \\
- \\
\text { March }\end{array}$ & $\begin{array}{l}\text { Prospectus } \\
\text { preparation. }\end{array}$ & $\begin{array}{l}\text { Prospectus } \\
\text { preparation. }\end{array}$ & $\begin{array}{l}\text { Prospectus } \\
\text { preparation. }\end{array}$ & $\begin{array}{l}\text { Prospectus } \\
\text { preparation. }\end{array}$ \\
\hline April & $\begin{array}{l}\text { Prospectus } \\
\text { preparation. }\end{array}$ & $\begin{array}{l}\text { Prospectus } \\
\text { preparation. }\end{array}$ & $\begin{array}{l}\text { First prospectus } \\
\text { approval meeting }\end{array}$ & $\begin{array}{l}\text { Prospectus } \\
\text { revisions. } \\
\text { Prepare } \\
\text { gatekeeper letters } \\
\text { and gain access } \\
\text { to field. }\end{array}$ \\
\hline May & $\begin{array}{l}\text { Prospectus } \\
\text { revisions. }\end{array}$ & $\begin{array}{l}2^{\text {nd }} \text { prospectus } \\
\text { approval date; } \\
\text { prospectus } \\
\text { approved }\end{array}$ & $\begin{array}{l}\text { Prospectus } \\
\text { revisions. }\end{array}$ & $\begin{array}{l}\text { Data collection: } \\
\text { Preliminary } \\
\text { interview with } \\
\text { special education } \\
\text { director and } \\
\text { institutions of } \\
\text { higher education. }\end{array}$ \\
\hline June & $\begin{array}{l}\text { Data collection: } \\
\text { Phone } \\
\text { conversations } \\
\text { with participants } \\
\text { to schedule } \\
\text { Interview \#1. } \\
\text { Signed } \\
\text { permission forms } \\
\text { to collected by } \\
\text { June 3, } 2005 \text {. }\end{array}$ & $\begin{array}{l}\text { Data collection: } \\
\text { First interviews } \\
\text { conducted and } \\
\text { transcribed. Data } \\
\text { analysis: } \\
\text { constant } \\
\text { comparative } \\
\text { method: Write. }\end{array}$ & $\begin{array}{l}\text { Data analysis: } \\
\text { constant } \\
\text { comparative } \\
\text { method: Write. }\end{array}$ & $\begin{array}{l}\text { Data collection: } \\
\text { Telephone } \\
\text { participants to } \\
\text { clarify data and } \\
\text { arrange Interview } \\
\text { \#2. Data } \\
\text { analysis: constant } \\
\text { comparative } \\
\text { method: Write. }\end{array}$ \\
\hline
\end{tabular}

Figure 3. Timetable for conducting the research related to practitioner knowledge base and preparation program training related to the administration of special education programs. 


\begin{tabular}{|c|c|c|c|c|}
\hline 2005 & Week 1 & Week 2 & Week 3 & Week 4 \\
\hline July & $\begin{array}{l}\text { Data collection: } \\
\text { Second } \\
\text { interviews } \\
\text { conducted and } \\
\text { transcribed. Data } \\
\text { analysis: } \\
\text { constant } \\
\text { comparative } \\
\text { method: Write. }\end{array}$ & $\begin{array}{l}\text { Data analysis: } \\
\text { constant } \\
\text { comparative } \\
\text { method: Write. }\end{array}$ & $\begin{array}{l}\text { Data collection: } \\
\text { Telephone } \\
\text { participants to } \\
\text { clarify data and } \\
\text { arrange Interview } \\
\text { \#3. Data } \\
\text { analysis: } \\
\text { constant } \\
\text { comparative } \\
\text { method: Write }\end{array}$ & $\begin{array}{l}\text { Data collection: } \\
\text { Third interviews } \\
\text { conducted and } \\
\text { transcribed. }\end{array}$ \\
\hline August & $\begin{array}{l}\text { Data collection: } \\
\text { Third interviews } \\
\text { conducted and } \\
\text { transcribed. }\end{array}$ & $\begin{array}{l}\text { Data collection: } \\
\text { Telephone } \\
\text { participants to } \\
\text { clarify data. } \\
\text { Data analysis: } \\
\text { constant } \\
\text { comparative } \\
\text { method: Write } \\
\end{array}$ & $\begin{array}{l}\text { Unitize data, } \\
\text { construct coding } \\
\text { categories, write } \\
\text { case narratives. }\end{array}$ & $\begin{array}{l}\text { Unitize data, } \\
\text { construct coding } \\
\text { categories, write } \\
\text { case narratives. }\end{array}$ \\
\hline $\begin{array}{c}\text { September } \\
- \\
\text { October }\end{array}$ & $\begin{array}{l}\text { Unitize data, } \\
\text { construct coding } \\
\text { categories, write } \\
\text { case narratives. }\end{array}$ & $\begin{array}{l}\text { Unitize data, } \\
\text { construct coding } \\
\text { categories, write } \\
\text { case narratives. }\end{array}$ & $\begin{array}{l}\text { Data analysis: } \\
\text { Constant } \\
\text { comparative } \\
\text { method: Write. } \\
\text { Schedule } \\
\text { dissertation } \\
\text { defense. }\end{array}$ & $\begin{array}{l}\text { Defense } \\
\text { preparation. }\end{array}$ \\
\hline November & $\begin{array}{l}\text { Schedule } \\
\text { dissertation } \\
\text { defense. }\end{array}$ & $\begin{array}{l}\text { Schedule } \\
\text { dissertation } \\
\text { defense. }\end{array}$ & $\begin{array}{l}\text { Final defense: } \\
\text { November 8, } \\
2005 \text {. }\end{array}$ & $\begin{array}{l}\text { Schedule } \\
\text { dissertation } \\
\text { defense. }\end{array}$ \\
\hline December & $\begin{array}{l}\text { Schedule } \\
\text { dissertation } \\
\text { defense. }\end{array}$ & $\begin{array}{l}\text { Schedule } \\
\text { dissertation } \\
\text { defense. }\end{array}$ & $\begin{array}{l}\text { December 28, } \\
2005 . \\
\text { Degree } \\
\text { conferring date. }\end{array}$ & \\
\hline
\end{tabular}

Figure 3. Timetable for conducting the research related to practitioner knowledge base and preparation program training related to the administration of special education programs. 
central focus of the study and any related emerging categories that the data revealed. A continuous winnowing process was employed as transcripts from previous interviews were reread. This was done to determine what data from the interviews were salient to the study. Finally, a summary of the findings deduced from the interviews was provided each participant for their review and confirmation so that the information fit the outline of the study as presented to them.

\section{Research Methods and Procedures}

Fieldwork, observation, surveys and interviewing often result in data from which important interpretations can be made. It can be said that all qualities are measures of all quantities and vise versa. Keeping that as a focus, in order to optimally attack a research problem, there are occasions to combine complementary methods to yield that result. Krathwohl (1998) stated, "Put another way, quantitative findings compress into summary numbers the trends and tendencies expressed in words in qualitative reports." and "Since qualitative and quantitative methods both offer views of the same world, they may turn up the same findings and usefully reinforce one another” (p. 619). Using a combined methodology and procedures within those methods, a process existed that allowed the researcher to be successively selective in his efforts to winnow the data to workable and usable information.

For all methods of research, the ultimate validation can be seen in the replication of the findings. Authenticity often is the issue (Silverman, 1993). The procedures used in this study provide that authenticity through surveys and selective sampling that generated both small and large samples to allow for interviewer-interviewee relationships. In essence, a qualitative account is accompanied by quantitative evidence. 


\section{Design of the Study}

The researcher used an exploratory case study design. In using this design, determining the type of research question to ask was an essential issue. Yin (1994) wrote, "To summarize, the first and most important condition for differentiating among the various research strategies is to identify the type of research question being asked” (p. 7). The research question focuses on what current special education directors felt was the necessary knowledge to fulfill the responsibilities of the position. Yin (1994) further noted, "In general, "what” questions may either be exploratory (in which case any of the strategies could be used) or about prevalence (in which surveys or the analysis of archival records would be favored)” (p. 7).

\section{Selection of Participants}

Cover letters (Appendix E) explaining the purpose of the study were sent to all participants. Each group, those responding to the survey and those selected for in depth responses, was provided with requests for their participation. Those requests included the promise of anonymity and confidentiality assuring the participants they would not be singled out in the study and of their right to drop out of the study at any time.

The data for analysis were gathered from a mixed method approach. Initially a survey was administered to the field of current special education directors $(n=56)$. This cell size was reduced by two to account for the researcher and one member of the committee $(n=54)$. Once data related to general demographics and perceptions of the knowledge base and training had been obtained and analyzed, selective sampling (J.Crockett, personal communication, February 23, 2005) was employed for the identification of the six interviewees from the field of current special education administrators $(n=54)$. Three sets of paired opposite factors were used that 
afforded an ample cross section from which a study group of current special education administrators was selected. The Office of Special Education at the West Virginia Department of Education was consulted to obtain the names of the individuals to satisfy each set of paired opposite factors.

The criteria for the selection of the practitioners were as follows:

1. The director of special education with the longest tenure in his or her current position.

2. The director of special education with the shortest tenure in his or her current position.

3. The director of special education in the county with the largest number of identified special education students as of the $2^{\text {nd }}$ Month Report for the school year $2003-2004$.

4. The director of special education in the county with the smallest number of identified special education students as of the $2^{\text {nd }}$ Month Report for the school year 2003 2004.

5. The director of special education in the county with the highest number of formal complaints filed with the West Virginia Department of Education, Office of Special Education for the school year 2003 - 2004.

6. The director of special education in the county with the least number of formal complaints filed with West Virginia Department of Education, the Office of Special Education for the school year 2003-2004.

In the event two or more directors or counties met the criteria in any given set, one was selected randomly from that group. Once each group of participants had been selected, the researcher 
used personal or phone interviews, follow-up interviews, and data collection techniques.

\section{Recording and Storing Data}

In respect to the confidentiality of the subjects of the study, all names were excluded and a descriptive moniker was conferred to each participant related to the qualitative aspects of the study. To ensure confidentiality for the subjects participating in the quantitative aspects of the study, each returned and usable survey was numbered, no other identification method was applied. Detailed notes from all field and phone interviews and audio recordings of those interviews were kept. Each recorded interview was transcribed with every line numbered. Each audio recording was labeled and numbered in sequence by the date of the interview and moniker of the subject interviewed. Participants were contacted by phone to clarify and verify any information that was unclear on the recording. All participants were given the opportunity to read through transcribed interviews to validate their accuracy.

Data were maintained in locked cabinets in a secure area at all times. The researcher was the only person to have immediate access to the area and data. All committee members were allowed access to the data upon written request.

\section{Data Analysis}

Qualitative data analysis was employed inductively through Maycut and Morehouse's (1994) constant comparative method to analyze the data. After transcription, each page of data was coded to assist with identification and then photocopied. Each page of data was unitized or identified as a unit of meaning. As Maycut and Morehouse (1994) defined it, "the process of qualitative data analysis is one of culling meaning from the words or actions of the participants in the study, framed by the researcher's focus of inquiry” (p 128). Once the data was unitized, it 
was continuously compared to data previously collected and categorized. This categorization procedure took on a semblance of what Lincoln and Guba (1985) referred to as “'feels right' or 'looks right' basis” (p. 340). The inductive nature of this study allowed for a refinement of categories to occur either by merging or omitting old categories or by creating new ones. This occurred if a unit did not easily blend with a known category or brought about the discovery and exploration of new relationships and patterns. As the units filled the individual categories, rules of inclusion were written to properly define each category so that propositions could be stated. Maycut and Morehouse (1994) wrote, "rules of inclusion, stated as propositions, begin to reveal what you are learning about the phenomenon you are studying and are a critical step in arriving at your research outcomes” (p. 139).

The analysis of the data in this way allowed this researcher to examine all propositions that were be stated as a result of the unitizing and categorizing processes. This examination afforded the investigator the opportunity to explore existing relationships, uncover new ones and discover emergent patterns in the data. Use of the constant comparative method permitted the exploration of data through the interviews. That method will either widen or narrow the focus of the study with the intent of yielding a better understanding of the phenomenon of interest to the researcher (Maycut and Morehouse, 1994). That same principle will provide a road map for future research in this area.

The quantitative data were analyzed using the Statistical Package for the Social Sciences (SPSS). This software package, while complex in design, was easy to use and allows for descriptive statistics. Basic descriptive statistics were used to calculate measures of central tendency and diversity: (a) the mean, (b) the median, and (c) the standard deviation. The 
directors' responses to the survey were reported related to demographics and for three domains. All domains utilized a modified Likert scale (Strongly Agree; Agree; Disagree; Strongly Disagree) with ascending numeric values assigned to the letter responses associated with the Likert scale. Negatively-phrased items were reverse-coded.

\section{Domains for the Survey}

Surveys affect our daily lives from what we eat, to what we watch on television, to how we vote. Who to survey is of major concern, being precise with the definition of the population is critical (Krathwohl, 1998).

Lincoln and Guba (1985) referred to an interview as a conversation with a purpose. Preparing the interview questions is an art (Payne, 1951). A factor within that art is inviting the interviewee to participate in a conversation (Maykut and Morehouse, 1994).

Three domains or areas of interest were conceived related to the research questions. The domains were as follows: (a) practitioner preparation, (b) skills learned on the job, and (c) building a special education administration program. Each domain included a bank of questions for current special education administrators based on the six types of questions Patton (1990) presented as a question typology: (a) experience/behavior, (b) opinion/value, (c) feelings, (d) knowledge, (e) sensory, and (f) background/demographic questions.

Once the domains and related questions had been roughed out, they were be submitted to selected, leading educators with research expertise and knowledge of the study for their comments. The input from these experts was used to help refine the development of the questions, their content, and the sequence in which they were presented. Once the domains and 
related questions were finalized, they were presented in accordance with the timetable for conducting the research.

\section{Questionnaire/Personal Interviews}

\section{Domain I - Special Education Director Preparation}

1) Please explain your current position and how long you have been in that position.

2) Please explain how you came to your current position.

Probe - For example: regular education teacher to general education administration course to principal then to director of special education.

3) What were the specific requirements in the job posting?

Probe - Was an administration endorsement required?

Probe - If so, is it general education or special education?

Probe - If not, are you in a program now?

4) Where did you receive your administrative training?

5) When did you complete your preparation program?

6) If you went through a general education administration program, were there any special education courses that were required?

Probe - If so, what were those courses?

Probe - Do you consider those knowledge base or leadership skill oriented?

7) Did your program include information necessary for managing a special education department? (Provide examples: special education law, finance, personnel laws)

Probe - For either Yes or No, please elaborate.

8) Did your program assist you to acquire leadership skills? 
(Provide examples: communication skills, interpersonal relationship skills)

Probe - If so, what specific skills were addressed?

9) Did you participate in role-playing that focused on problem solving special education issues?

Probe - If so, please elaborate.

10) How well did your administrative endorsement preparation program prepare you for your current position?

Probe -What specific knowledge base should have been offered?

Probe - What specific leadership skills should have been offered?

Domain II - Skills Learned on the Job

1) Describe your sense of readiness when you entered your current position.

Probe - Do you feel your knowledge base was sufficient?

Probe - How did that impact your position?

2) What knowledge base, relevant to your current position, was lacking?

Probe - What other areas of knowledge would have assisted you in the position?

Examples - paperwork, procedural compliance, parent complaints, budgeting.

Probe - How did that impact your ability to manage daily tasks and accomplish your goals.

3) How have you expanded your knowledge base in a deliberate way?

Probe - Peers, professional organization, professional literature?

Probe - How has that impacted your ability to manage daily tasks, accomplish 
your goals, establish a vision?

4) Please describe the leadership skills you feel you did not have at the time you entered your current position.

Probe - How did that impact your ability to manage daily tasks and accomplish your goals?

5) Have you expanded your leadership skills in a deliberate way?

Probe - Peers, professional organization, professional literature?

Probe - How has that impacted your ability to manage daily tasks, accomplish your goals, establish a vision?

6) For a new director faced with the continuous changes in federal and state policy related to special education, how long did it take you to feel you were effective providing leadership?

Probe - Consider areas such as litigation, discipline, parent relations.

7) Describe a situation in which you did not possess the necessary knowledge or leadership skills to resolve.

Domain III - Building a Special Education Administration Program

1) Should West Virginia require a specific administration endorsement for directors of special education?

Probe - If so, what components should the program include?

Probe - How many hours of course work should it require?

Probe - What courses should be offered? 
2) If not, what knowledge and skills related to special education administration should be offered through the general administration program?

3) Regardless of the program (general or special education), should that course work include role-playing that focuses on problem solving involving special education issues?

Probe - Please elaborate on scenarios you feel would be relevant for role playing.

Directors of Special Education Perceptions

Survey

Please circle the option that best describes your current situation.

Gender: $\mathrm{M}$ F

I have taught special education classes in the public school setting.

Y N

I have been in my current position:

1 to 5 years 6 to 10 years 11 to 15 years 16 to 20 years 21 to 25 years 26 years plus

My highest educational degree is: Bachelors Masters Doctorate

I currently have an administrative endorsement. $\quad \mathrm{Y} N$

(If you answered "N" to the above question, please go directly to Section II - Skills Learned on the Job.)

My administrative endorsement is through a general education administration program.

Y N

My administrative endorsement is through a program specifically designed for the administration of special education programs.

I received my administrative endorsement from Y N year

Please circle the letter that best describes your preparation and knowledge base for your current position.

$$
\mathbf{A}=\text { Strongly Agree } \quad \mathbf{B}=\text { Agree } \quad \mathbf{C}=\text { Disagree } \quad \mathbf{D}=\text { Strongly Disagree }
$$

\section{Special Education Director Preparation:}

1. My graduate level administrative program included role-playing that focused on problem solving special education issues.

2. My administrative program provided an appropriate number of school law courses.

3. My training program provided an appropriate number of special education law courses.

4. My graduate level administrative program did not offer any special education courses. A B C D

5. My graduate level administrative program prepared me to chair an IEP meeting. A B C D

6. My administrative program provided specific course work related to leadership skills. A B C D

7. My graduate level administrative program adequately prepared me for my current position. 


\section{Skills Learned on the Job:}

1. My ability to work with parents as valued members of the IEP process was a skill developed on the job.

2. My current position offers me the opportunity to enhance my ability to work with the increasing concerns related to the cultural diversity of students with disabilities.

3. My ability to develop and implement a budget to address the needs of students with disabilities was not acquired on the job.

4. My ability to effectively communicate federal and state policy related to the delivery of special education services was a skill developed while in my current position.

5. My on the job experiences have been more helpful with my job related responsibilities than my course work.

\section{Building a Better Education Administration Program:}

1. Administrative internships should include a unit that focuses on the administration of programs for students with disabilities.

2. All education administration programs should require at least 1 special education law course and 1 general school law course.

3. Graduate level education administration programs should include role playing that focuses on problem solving special education issues.

4. Graduate level education administration programs should include 9 hours of special education course work.

5. Course work devoted to leadership skills is not needed in graduate level education administration programs.

6. West Virginia should require a specific administration endorsement for directors of special education. 


\section{CHAPTER 4}

Findings:

Context

Mertler and Charles (2005) indicate, "Research conclusions cannot be taken seriously if there is question about the quality of the data from which the conclusions are drawn” (p. 39). They further state, “all research is value-laden. Researchers investigate what they believe to be important, and they look for - and certainly hope for - results that can make a practical difference in education” (p. 176). With this in mind, the researcher worked with several leading educators to strengthen the design of this study. The outcome of that work was a mixed design employing quantitative and qualitative approaches to assess the perceptions of directors of special education. The quantitative approach employed a survey consisting of three domains. The qualitative approach involved a questionnaire and a series of follow-up interviews. The focus was related to administrators’ perceptions of the needed knowledge base for their current positions and how those skills were acquired.

Of the 56 directors asked to complete the survey, 47 responded, two surveys were not used due to incomplete responses, making the sample size $n=45$. The high rate of return (83.9\%) of all surveys is in part attributed to the survey being distributed at a state wide meeting for special education directors. The researcher was able to personally explain the purpose of the study and to clarify any questions the prospective respondents had. The response rate of usable surveys was $80.4 \%$. Two-fifths of the respondents were male $(n=18,40 \%)$, while three-fifths were female ( $n=27,60 \%$ ). The survey was handed out to the directors on June 23, 2005; the last collection date was July 23, 2005. 
The reader is cautioned here to keep in mind when reading the quantitative data analysis that while 45 surveys were used, only 35 of the respondents had administrative endorsements. This is important to remember in that when the Demographics and the first domain, Special Education Director Preparation, are discussed related to all respondents, those respondents who did not have an endorsement completed only part of the Demographic questions and none of the Special Education Director Preparation domain. A separate analysis of the responses for those respondents without an administrative endorsement is provided describing their responses for the applicable sections. An analysis of that group is also provided separating the responses of the males and those for the females.

Six directors, chosen by using selective sampling from three sets of paired opposite factors, were selected for more in-depth interviews related to the survey. The majority of the respondents to the interviews were female $(n=5,83.3 \%)$ while one-sixth were male $(n=1$, 16.7\%). The in-depth questionnaires and follow-up interviews were conducted between July 1, 2005, and September 15, 2005.

The results presented in this chapter broach both the respondents to the survey and the questionnaire with follow-up interviews. First, a description of the demographics for the sample of respondents of the survey is presented. Descriptive statistics, using the Statistical Package for the Social Sciences (SPSS), then provide for analysis of the respondents' perceptions as measured by an ordinal scale related to the survey. The SPSS address the data from three perspectives: (a) all respondents, (b) male and female respondents, and (c) respondents with an administration endorsement and those without an endorsement. Finally, the findings of the qualitative results of the directors' responses to the interviews is provided as derived using the 
constant comparative method (Maykut and Morehouse, 1994).

\section{Quantitative Analysis}

Basic descriptive statistics were used to calculate measures of central tendency and diversity: (a) the mean, (b) the median, and (c) the standard deviation (Appendix D). In addition to demographic information for the directors, their responses to the survey were reported for three domains. All domains utilized a modified Likert type scale (Strongly Agree; Agree; Disagree; Strongly Disagree) with ascending numeric values assigned to the letter responses associated with the Likert type scale. Negatively-phrased items were reverse-coded. SPSS version13.0.1 (SPSS, 2004) was used in the analysis of the data.

\section{Demographics for All Respondents}

The reader needs to remember this section of the Demographics pertain to all 45 respondents (Appendix A). The majority of the respondents were female ( $n=27,60 \%)$ while males made up $40 \%(n=18)$ of the respondents. A large majority $(n=33,73.3 \%)$ of the respondents indicated having taught in a public school special education classroom. Related to the years of experience the respondents had in their current position, the range was wide with 6 separate year spans. The newer directors represented the majority of respondents, 1 to 5 years (n $=18,40 \%)$ and 6 to 10 years $(n=15,33.3 \%)$. Five directors $(11.1 \%)$ made up the third range, 11 to 15 years. The span 15 to 20 years, had two respondents (4.4\%). The fourth span, 21 to 25 years, comprised three members (6.8\%), while the final span, 26 years plus, had two individuals (4.4\%). The degree level of the respondents revealed none (0\%) of the respondents had a only bachelors’ degree, 40 (88.9\%) have a masters’ degree, while five (11.1\%) respondents have their doctorate. 
This next section of the Demographics pertained only to those with an administrative endorsement. Of these respondents, 35 (77.8\%) indicated they held an endorsement, with 10 (22.2\%) not having one. Of the 35 respondents who held an administrative endorsement, the majority $(n=33,94.3 \%)$ indicated their endorsement was through a general education administration program. Two (5.7\%) of those 35 respondents also noted having an endorsement through a program specifically designed for the administration of special education programs. Most of the respondents $(n=13,37.1 \%)$ who held an endorsement attended West Virginia University, 12 (34.3\%) attended Marshall University, 5 (14.3\%) attended The College of Graduate Studies, 2 (5.7\%) attended Salem University, 2 (5.7\%) attended Virginia Polytechnic Institute and State University, and 1 (2.9\%) attended Frostburg State. The range in years that the respondents received their endorsements was from 1972 to 2005 . Three (8.6\%) received endorsements during the 1970s. The 1980s had eight respondents (22.9\%) receiving endorsements. The majority $(n=15,42.8 \%)$ of the respondents received endorsements during the 1990s, while 9 (25.7\%) have received endorsements during the 2000s.

\section{Demographics - All Male and Female Respondents.}

The response of 18 males was evenly divided $(n=9,50 \%)$ for those who had and those who had not taught special education classes before becoming a director. Of the 27 females in the survey, an overwhelming majority $(n=24,88.9 \%)$ indicated they had taught special education classes at the public school level before becoming a director. The newer directors, those within the ranges of the 1 to 5 years experience $(n=6,33.3 \%)$ and 6 to 10 years $(n=4$, years experience. The ranges, 16 to 20 years and 21 to 25 years, each had two males (11.1\%), while only one male (5.6\%) had 26 or more years of experience in his current position. Like 
their male counterparts, the majority of the female respondents fell in the newer director ranges, 1 to 5 years $(n=12,44.4 \%)$ and 6 to 10 years $(n=11,40.7 \%)$. Two females $(7.5 \%)$ fell in the third range, 11 to 15 years. No female respondents (0\%) fell in the 16 to 20 years range, while the final ranges, 21 to 25 years and 26 plus years, each had one respondent (3.7\%). None (0\%) of the male respondents held only a Bachelors’ degree. Fifteen (83.3\%) held a Masters’ degree, while three (16.7\%) held a Doctorate. None of the female (0\%) respondents held a Bachelors' degree. The majority $(n=25,92.6 \%)$ held a Masters' degree, while only two $(7.4 \%)$ held a Doctorate.

This next section of the Demographics pertained only to those males ( $\mathrm{n}=13,72.2 \%)$ and females ( $n=22,81.5 \%)$ with an administrative endorsement (Appendices B \& C). The vast majority of males $(\mathrm{n}=12,92.3 \%)$ held an endorsement through a general administration program, while only one (7.7\%) had an endorsement through a program specifically designed for the administration of special education programs. Likewise, the vast majority of females ( $\mathrm{n}=21$, 95.5\%) held an endorsement through a general administration program, while only one (4.5\%) held an endorsement through a program specifically designed for the administration of special education programs. It is of interest that two (9.5\%) of the 21 female respondents with a general education administrative endorsement indicated they also held one designed specifically for special education programs.

Of the state's two major universities, six male respondents (46.2\%) who held an endorsement attended West Virginia University, while 4 (30.7\%) attended Marshall University. Frostburg State, The College of Graduate Studies, and Virginia Polytechnic Institute and State University each had one attendee (7.7\%). None of the males (0\%) indicated their endorsement 
was from Salem University. The state’s two major universities, West Virginia University ( $\mathrm{n}=7$, 31.8\%) and Marshall University ( $\mathrm{n}=9,40.9 \%)$, were the institutions of higher learning from which a majority of the female respondents received their endorsements. Three of the respondents (13.7\%) indicated their endorsements were earned through The College of Graduate Studies. Two female respondents (9.1\%) received their endorsements from Salem University, while Virginia Polytechnic Institute and State University had one attendee (4.5\%). None of the females (0\%) indicated their endorsement was from Frostburg State. The range in years when the male respondents received their endorsement was from 1972 to 2004 . Three (23.1\%) received their endorsement during the 1970s. The 1980s had five respondents (38.5\%) receive their endorsement. Another 23.1\% ( $n=3)$ of the respondents received endorsements during the 1990s, while two (15.3\%) received endorsements during the 2000s. The range in years that the female respondents received endorsements was from 1981 to 2005 . None (0\%) of the females received endorsements during the 1970s. The 1980s had three respondents (13.6\%) receiving endorsements. Most of the female respondents $(n=12,54.5 \%)$ received endorsements during the 1990s, while another seven (31.9\%) received endorsements during the 2000s.

\section{Domains}

The domains were designed to draw on the perceptions of the respondents related to their own formal preparation, on the job training, and building an ideal preparation program. The sets of questions in each domain utilized a modified Likert type scale (Strongly Agree; Agree;

Disagree; Strongly Disagree). The first set of questions consisted of seven items and addresses Special Education Director Preparation. Directors' responses to this set yielded a Cronbach's Alpha measure of reliability equal to .816. The second set, Skills Learned on the Job, consisted 
of five items. Here, the responses yielded a Cronbach’s Alpha of .404. The final set, comprised of six questions, addresses Building a Better Education Administration Program. The Cronbach’s Alpha for this set was .534.

Special Education Director Preparation.

The seven items contained in this domain of the survey pertained to the directors' perceptions of the adequacy of their formal training received in the preparation programs. Since this domain was not completed by all respondents, but only by those with an administrative endorsement, it is presented under the discussion for that group of respondents. At that time, an analysis is provided for all respondents with an endorsement followed a break down for male and female respondents.

\section{Skills Learned On-The-Job-All Respondents}

The five items presented in this domain addressed the directors’ perceptions related to areas they felt were learned while carrying out the responsibilities of the position. The directors ( $\mathrm{n}=44,97.8 \%$ ) overwhelming indicated they acquired their ability to work with parents as valued members of the IEP process while on the job. A majority $(n=38,84.5 \%)$ of the respondents felt their ability to work with the increasing demands related to cultural diversity was acquired from on-the-job experiences. In response to a reverse order question, a majority (n $=33,73.3 \%$ ) indicated they did learn how to develop and implement a budget to address the needs of students with disabilities while in their position.

Most ( $\mathrm{n}=42,93.3 \%$ ) of the respondents did indicate their ability to effectively communicate federal and state policy related to special needs students was acquired while in their current position. A large majority $(n=40,88.9 \%)$ indicated the on-the-job experiences 
were more helpful to them related to the responsibilities of their current position than their coursework was (see Table 5).

\section{Skill Learned on the Job -- Male and Female Respondents.}

All $(\mathrm{n}=18,100 \%)$ of the male respondents indicated they acquired their ability to work with parents as valued members of the IEP process while on the job. Almost all $(n=26,96.3 \%)$ of the female respondents indicated they acquired their ability to work with parents as valued members of the IEP process while on the job. Almost all $(n=17,94.4 \%)$ of the males felt their ability to work with the increasing demands related to cultural diversity was acquired from on the job experiences. A majority ( $\mathrm{n}=21,77.8 \%$ ) of the females felt their ability to work with the increasing demands related to cultural diversity was acquired from on-the-job experiences. In response to a reverse order question, two-thirds ( $\mathrm{n}=12,66.6 \%$ ) of the male respondents indicated they did learn while in their current position how to develop and implement a budget to address the needs of students with disabilities. To that same question, a majority $(n=21,77.7 \%)$ of the female respondents indicated they did learn while in their current position how to develop and implement a budget to address the needs of students with disabilities. Almost all ( $\mathrm{n}=17$, 94.4\%) of the male respondents did indicate their ability to effectively communicate federal and state policy related to special needs students was acquired while in their current position. Almost all $(n=25,92.6 \%)$ of the female respondents did indicate their ability to effectively communicate federal and state policy related to special needs students was acquired while in their current position. Again, almost all $(\mathrm{n}=17,94.4 \%)$ of the male respondents indicated the on-the-job experiences were more helpful to them related to the responsibilities of their current position than their coursework was. Most $(n=23,85.2 \%)$ of the female respondents indicated 
Table 5

Skills Learned On-The-Job - All Respondents

Descriptor

Subject Response

\begin{tabular}{|c|c|c|c|c|}
\hline & $\begin{array}{l}\text { Strongly } \\
\text { Agree }\end{array}$ & Agree & Disagree & $\begin{array}{l}\text { Strongly } \\
\text { Disagree }\end{array}$ \\
\hline $\begin{array}{l}\text { My ability to work with parents as valued members of the } \\
\text { IEP process was a skill developed on the job. }\end{array}$ & $\begin{array}{c}32 \\
(71.1 \%)\end{array}$ & $\begin{array}{c}12 \\
(26.7 \%)\end{array}$ & $\begin{array}{c}0 \\
(0.0 \%)\end{array}$ & $\begin{array}{c}1 \\
(2.2 \%)\end{array}$ \\
\hline $\begin{array}{l}\text { My current position offers me the opportunity to enhance } \\
\text { my ability to work with the increasing concerns related to } \\
\text { the cultural diversity of students with disabilities. }\end{array}$ & $\begin{array}{c}21 \\
(46.7 \%)\end{array}$ & $\begin{array}{c}17 \\
(37.8 \%)\end{array}$ & $\begin{array}{c}6 \\
(13.3 \%)\end{array}$ & $\begin{array}{c}1 \\
(2.2 \%)\end{array}$ \\
\hline $\begin{array}{l}\text { My ability to develop and implement a budget to address } \\
\text { the needs of students with disabilities was not acquired } \\
\text { on the job. }\end{array}$ & $\begin{array}{l}3 \\
(6.7 \%)\end{array}$ & $\begin{array}{c}9 \\
(20.0 \%)\end{array}$ & $\begin{array}{c}13 \\
(28.9 \%)\end{array}$ & $\begin{array}{c}20 \\
(44.4 \%)\end{array}$ \\
\hline $\begin{array}{l}\text { My ability to effectively communicate federal and state } \\
\text { policy related to the delivery of special education services } \\
\text { was a skill developed while in my current position. }\end{array}$ & $\begin{array}{c}22 \\
(48.9 \%)\end{array}$ & $\begin{array}{c}20 \\
(44.4 \%)\end{array}$ & $\begin{array}{l}3 \\
(6.7 \%)\end{array}$ & $\begin{array}{c}0 \\
(0.0 \%)\end{array}$ \\
\hline $\begin{array}{l}\text { My on the job experiences have been more helpful with } \\
\text { my job related responsibilities than my coursework. }\end{array}$ & $\begin{array}{c}30 \\
(66.7 \%)\end{array}$ & $\begin{array}{c}10 \\
(22.2 \%)\end{array}$ & $\begin{array}{c}5 \\
(11.1 \%)\end{array}$ & $\begin{array}{c}0 \\
(0.0 \%)\end{array}$ \\
\hline
\end{tabular}

Note: Domain 2. Descriptors and subject response for skills learned on-the-job for all respondents. 
the on-the-job experiences were more helpful to them related to the responsibilities of their current position than their coursework was (see Table 6).

Building a Better Education Administration Program -- All Respondents.

The final domain consisted of six questions seeking the respondents perceptions of building a better education administration program related to special education. Almost all $(\mathrm{n}=$ 43, 95.6\%) of the respondents felt administrative internships should include a unit focusing on the administration of programs for students with disabilities. Again, almost all $(n=43,95.6 \%)$ of the respondents indicated all education administration programs should require at least one special education law course and one general school law course. A majority of the respondents ( $n=37,82.2 \%$ ) felt graduate level education administration programs should include role playing that focused on problem solving special education issues. Several $(n=34,75.6 \%)$ of the respondents indicated they favored education administration programs including nine hours of special education course work. In response to a reverse order question, a majority ( $\mathrm{n}=39$, 86.7\%) of the respondents felt course work devoted to leadership skills was needed in graduate level education administration programs. Less than half $(n=19,42.2 \%)$ of the respondents indicated West Virginia should require a specific administration endorsement for directors of special education (see Table 7).

Building a Better Education Administration Program - Male and Female Respondents.

Almost all ( $n=17,94.4 \%)$ of the male respondents felt administrative internships should include a unit focusing on the administration of programs for students with disabilities. Almost all ( $n=26,96.3 \%)$ of the female respondents felt administrative internships should include a unit focusing on the administration of programs for students with disabilities. A majority of male 
Table 6

Skills Learned on the Job Male and Female Respondents

Descriptor

Subject Response

Males

My ability to work with parents as valued members of the IEP process was a skill developed on the job.

My current position offers me the opportunity to enhance my ability to work with the increasing concerns related to the cultural diversity of students with disabilities.

My ability to develop and implement a budget to address the needs of students with disabilities was not acquired on the job.

My ability to effectively communicate federal and state policy related to the delivery of special education services was a skill developed while in my current position.

My on the job experiences have been more helpful with my job related responsibilities than my coursework.

\section{Females}

My ability to work with parents as valued members of the IEP process was a skill developed on the job.

My current position offers me the opportunity to enhance my ability to work with the increasing concerns related to the cultural diversity of students with disabilities.

My ability to develop and implement a budget to address the needs of students with disabilities was not acquired on the job.

My ability to effectively communicate federal and state policy related to the delivery of special education services was a skill developed while in my current position.

My on the job experiences have been more helpful with my job related responsibilities than my coursework.

\begin{tabular}{|c|c|c|c|}
\hline $\begin{array}{l}\text { Strongly } \\
\text { Agree }\end{array}$ & Agree & Disagree & $\begin{array}{l}\text { Strongly } \\
\text { Disagree }\end{array}$ \\
\hline $\begin{array}{c}12 \\
(66.7 \%)\end{array}$ & $\begin{array}{c}6 \\
(33.3 \%)\end{array}$ & $\begin{array}{c}0 \\
(0 \%)\end{array}$ & $\begin{array}{c}0 \\
(0.0 \%)\end{array}$ \\
\hline $\begin{array}{c}10 \\
(55.6 \%)\end{array}$ & $\begin{array}{c}7 \\
(38.8 \%)\end{array}$ & $\begin{array}{c}1 \\
(5.6 \%)\end{array}$ & $\begin{array}{c}0 \\
(0.0 \%)\end{array}$ \\
\hline $\begin{array}{c}1 \\
(5.6 \%)\end{array}$ & $\begin{array}{c}5 \\
(27.8 \%)\end{array}$ & $\begin{array}{c}4 \\
(22.2 \%)\end{array}$ & $\begin{array}{c}8 \\
(44.4 \%)\end{array}$ \\
\hline $\begin{array}{c}9 \\
(50.0 \%)\end{array}$ & $\begin{array}{c}8 \\
(44.4 \%)\end{array}$ & $\begin{array}{c}1 \\
(5.6 \%)\end{array}$ & $\begin{array}{c}0 \\
(0.0 \%)\end{array}$ \\
\hline $\begin{array}{c}14 \\
(77.8 \%)\end{array}$ & $\begin{array}{c}3 \\
(16.6 \%)\end{array}$ & $\begin{array}{c}1 \\
(5.6 \%)\end{array}$ & $\begin{array}{c}0 \\
(0.0 \%)\end{array}$ \\
\hline $\begin{array}{c}20 \\
(74.1 \%)\end{array}$ & $\begin{array}{c}6 \\
(22.2 \%)\end{array}$ & $\begin{array}{c}0 \\
(0.0 \%)\end{array}$ & $\begin{array}{c}1 \\
(3.7 \%)\end{array}$ \\
\hline $\begin{array}{c}11 \\
(40.7 \%)\end{array}$ & $\begin{array}{c}10 \\
(37.1 \%)\end{array}$ & $\begin{array}{c}5 \\
(18.5 \%)\end{array}$ & $\begin{array}{c}1 \\
(3.7 \%)\end{array}$ \\
\hline $\begin{array}{c}2 \\
(7.4 \%)\end{array}$ & $\begin{array}{c}4 \\
(14.9 \%)\end{array}$ & $\begin{array}{c}9 \\
(33.3 \%)\end{array}$ & $\begin{array}{c}12 \\
(44.4 \%)\end{array}$ \\
\hline $\begin{array}{c}13 \\
(48.2 \%)\end{array}$ & $\begin{array}{c}12 \\
(44.4 \%)\end{array}$ & $\begin{array}{c}2 \\
(7.4 \%)\end{array}$ & $\begin{array}{c}0 \\
(0.0 \%)\end{array}$ \\
\hline $\begin{array}{c}16 \\
(59.3 \%)\end{array}$ & $\begin{array}{c}7 \\
(25.9 \%)\end{array}$ & $\begin{array}{c}4 \\
(14.8 \%)\end{array}$ & $\begin{array}{c}0 \\
(0.0 \%)\end{array}$ \\
\hline
\end{tabular}

Note: Domain 2. Descriptors and subject response for skills learned on-the-job for all males and females. 
respondents $(\mathrm{n}=16,88.9 \%)$ indicated all education administration programs should require at least one special education law course and one general school law course. All of the female respondents $(\mathrm{n}=27,100 \%)$ indicated all education administration programs should require at least one special education law course and one general school law course. Several of the male respondents $(n=14,77.7 \%)$ felt graduate level education administration programs should include role playing that focused on problem solving special education issues. A majority of the female ( $\mathrm{n}=23,85.2 \%)$ felt graduate level education administration programs should include role playing that focused on problem solving special education issues. Over half $(n=11,61.1 \%)$ of the male respondents indicated they favored education administration programs including nine hours of special education course work. A majority $(n=23,85.2 \%)$ of the female respondents indicated they favored education administration programs including nine hours of special education course work.

A majority ( $n=16,88.8 \%)$ of the males, in response to a reverse order question, felt course work devoted to leadership skills was needed in graduate level education administration programs. Likewise, a majority ( $n=23,85.2 \%$ ) of the females in response to the same question, felt course work devoted to leadership skills was needed in graduate level education administration programs. Less than one-fourth $(n=4,22.3 \%)$ of the male respondents indicated West Virginia should require a specific administration endorsement for directors of special education. Just over half $(\mathrm{n}=15,55.6 \%)$ of the female respondents indicated West Virginia should require a specific administration endorsement for directors of special education (see Table 8). 
Table 7

Building a Better Education Administration Program All Respondents

Descriptor Subject Response

Administrative internships should include a unit that focuses on the administration of programs for students with disabilities.

All education administration programs should require at least one special education law course and one general school law course.

Graduate level education administration programs should include role playing that focuses on problem solving special education issues.

Graduate level education administration programs should include 9 hours of special education course work.

Course work devoted to leadership skills is not needed in graduate level education administration programs.

West Virginia should require a specific administration endorsement for directors of special education.

\begin{tabular}{|c|c|c|c|}
\hline $\begin{array}{l}\text { Strongly } \\
\text { Agree }\end{array}$ & Agree & Disagree & $\begin{array}{l}\text { Strongly } \\
\text { Disagree }\end{array}$ \\
\hline $\begin{array}{c}29 \\
(64.5 \%)\end{array}$ & $\begin{array}{c}14 \\
(31.1 \%)\end{array}$ & $\begin{array}{c}1 \\
(2.2 \%)\end{array}$ & $\begin{array}{c}1 \\
(2.2 \%)\end{array}$ \\
\hline $\begin{array}{c}28 \\
(62.3 \%)\end{array}$ & $\begin{array}{c}15 \\
(33.3 \%)\end{array}$ & $\begin{array}{c}2 \\
(4.5 \%)\end{array}$ & $\begin{array}{c}0 \\
(0.0 \%)\end{array}$ \\
\hline $\begin{array}{c}14 \\
(31.1 \%)\end{array}$ & $\begin{array}{c}23 \\
(51.1 \%)\end{array}$ & $\begin{array}{c}6 \\
(13.3 \%)\end{array}$ & $\begin{array}{c}2 \\
(4.5 \%)\end{array}$ \\
\hline $\begin{array}{c}12 \\
(26.7 \%)\end{array}$ & $\begin{array}{c}22 \\
(48.9 \%)\end{array}$ & $\begin{array}{c}8 \\
(17.7 \%)\end{array}$ & $\begin{array}{c}3 \\
(6.7 \%)\end{array}$ \\
\hline $\begin{array}{c}4 \\
(8.9 \%)\end{array}$ & $\begin{array}{c}2 \\
(4.4 \%)\end{array}$ & $\begin{array}{c}10 \\
(22.2 \%)\end{array}$ & $\begin{array}{c}29 \\
(64.5 \%)\end{array}$ \\
\hline $\begin{array}{c}6 \\
(13.3 \%)\end{array}$ & $\begin{array}{c}13 \\
(28.9 \%)\end{array}$ & $\begin{array}{c}13 \\
(28.9 \%)\end{array}$ & $\begin{array}{c}13 \\
(28.9 \%)\end{array}$ \\
\hline
\end{tabular}

Note: Domain 3. Descriptors and subject response for building a better education administration program for all respondents. 
With an Endorsement

Demographics for All Respondents with an Endorsement.

Of the total number of respondents $(n=45), 35(77.8 \%)$ indicated having an administrative endorsement. The majority of the respondents with an administrative endorsement were female ( $n=22,62.9 \%$ ) while fewer than half of the males $(n=13,37.1 \%$ ) held an endorsement. A large majority $(n=25,71.4 \%)$ of the respondents indicated having taught in a public school special education classroom. Related to the years of experience the respondents had in their current position, the range was wide with 6 separate year spans. The newer directors represented the majority of respondents, 1 to 5 years ( $n=14,40 \%$ ) and 6 to 10 years $(\mathrm{n}=14,40 \%)$. Three directors $(8.6 \%)$ made up the third range, 11 to 15 years. The fourth span, 16 to 20 years, had one respondent (2.8\%). The fifth span, 21 to 25 years, comprised three members (8.6\%). None of the respondents (0\%) fell in the final span, 26 years plus. The degree level of the respondents revealed none (0\%) of the respondents having only a Bachelors' degree, 30 (85.7\%) have a Masters’ degree, while five (14.3\%) respondents have their Doctorate. Of the 35 respondents who held an administrative endorsement, the majority ( $n=33,94.3 \%$ ) indicated their endorsement was through a general education administration program. Two (6.1\%) of those 33 respondents also noted having an endorsement through a program specifically designed for the administration of special education programs. Most of the respondents ( $\mathrm{n}=13,37.1 \%$ ) who held an endorsement attended West Virginia University, 12 (34.3\%) attended Marshall University, 5 (14.3\%) attended The College of Graduate Studies, 2 (5.7\%) attended Salem University, 2 (5.7\%) attended Virginia Polytechnic Institute and State University, and 1 (2.9\%) attended Frostburg State. The range in years when the respondents received their endorsements 
Table 8

Building a Better Education Administration Program All Male and Female Respondents

\begin{abstract}
Males
Administrative internships should include a unit that focuses on the administration of programs for students with disabilities.

All education administration programs should require at least one special education law course and one general school law course.

Graduate level education administration programs should include role playing that focuses on problem solving special education issues.
\end{abstract}

Graduate level education administration programs should include 9 hours of special education course work.

Course work devoted to leadership skills is not needed in graduate level education administration programs.

West Virginia should require a specific administration endorsement for directors of special education.

\section{Females}

Administrative internships should include a unit that focuses on the administration of programs for students with disabilities.

All education administration programs should require at least one special education law course and one general school law course.

Graduate level education administration programs should include role playing that focuses on problem solving special education issues.

Graduate level education administration programs should include 9 hours of special education course work.

Course work devoted to leadership skills is not needed in graduate level education administration programs.

West Virginia should require a specific administration endorsement for directors of special education.

\begin{tabular}{|c|c|c|c|}
\hline $\begin{array}{l}\text { Strongly } \\
\text { Agree }\end{array}$ & Agree & Disagree & $\begin{array}{l}\text { Strongly } \\
\text { Disagree }\end{array}$ \\
\hline $\begin{array}{c}11 \\
(61.1 \%)\end{array}$ & $\begin{array}{c}6 \\
(33.3 \%)\end{array}$ & $\begin{array}{c}0 \\
(0.0 \%)\end{array}$ & $\begin{array}{c}1 \\
(5.6 \%)\end{array}$ \\
\hline $\begin{array}{c}10 \\
(55.6 \%)\end{array}$ & $\begin{array}{c}6 \\
(33.3 \%)\end{array}$ & $\begin{array}{c}2 \\
(11.1 \%)\end{array}$ & $\begin{array}{c}0 \\
(0.0 \%)\end{array}$ \\
\hline $\begin{array}{c}6 \\
(33.3 \%)\end{array}$ & $\begin{array}{c}8 \\
(44.4 \%)\end{array}$ & $\begin{array}{c}3 \\
(16.7 \%)\end{array}$ & $\begin{array}{c}1 \\
(5.6 \%)\end{array}$ \\
\hline $\begin{array}{c}4 \\
(22.2 \%)\end{array}$ & $\begin{array}{c}7 \\
(38.9 \%)\end{array}$ & $\begin{array}{c}4 \\
(22.2 \%)\end{array}$ & $\begin{array}{c}3 \\
(16.7 \%)\end{array}$ \\
\hline $\begin{array}{c}1 \\
(5.6 \%)\end{array}$ & $\begin{array}{c}1 \\
(5.6 \%)\end{array}$ & $\begin{array}{c}5 \\
(27.7 \%)\end{array}$ & $\begin{array}{c}11 \\
(61.1 \%)\end{array}$ \\
\hline $\begin{array}{c}1 \\
(5.6 \%)\end{array}$ & $\begin{array}{c}3 \\
(16.7 \%)\end{array}$ & $\begin{array}{c}9 \\
(50.0 \%)\end{array}$ & $\begin{array}{c}5 \\
(27.7 \%)\end{array}$ \\
\hline
\end{tabular}

$\begin{array}{cccc}18 & 8 & 1 & 0 \\ (66.7 \%) & (29.6 \%) & (3.7 \%) & (0.0 \%) \\ 18 & 9 & 0 & 0 \\ (66.7 \%) & (33.3 \%) & (0.0 \%) & (0.0 \%) \\ 8 & 15 & 3 & 1 \\ (29.6 \%) & (55.6 \%) & (11.1 \%) & (3.7 \%) \\ 8 & 15 & 4 & 0 \\ (29.6 \%) & (55.6 \%) & (14.8 \%) & (0.0 \%) \\ 3 & 1 & 5 & 18 \\ (11.1 \%) & (3.7 \%) & (18.5 \%) & (66.7 \%) \\ 5 & 10 & 4 & 8 \\ (18.5 \%) & (37.1 \%) & (14.8 \%) & (29.6 \%)\end{array}$

Note: Domain 3: Descriptors and subject responses for building a better education administration program for all male and female respondents. 
was from 1972 to 2005 . Three (8.6\%) received their endorsement during the 1970s. The 1980s had eight respondents (22.9\%) receive their endorsement. The majority $(n=15,42.8 \%)$ of the respondents received their endorsement during the 1990s, while 9 (25.7\%) have received their endorsements during the 2000s.

Demographics - Males and Females with an Endorsement.

Of the 13 males with an endorsement, almost half $(n=6,46.1 \%)$ indicated they taught in a public school special education classroom prior to becoming a director. Of the 22 females with an endorsement, the majority $(\mathrm{n}=19,86.4 \%)$ indicated they taught in a public school special education classroom prior to becoming a director. The newer directors of the males, those in the 1 to 5 year span $(n=5,38.5 \%)$ and 6 to 10 year span $(n=4,30.8 \%)$, comprised a majority of the respondents. The spans for 11 to 15 years and 16 to 20 years each had one respondent $(7.7 \%)$. The fifth span, 21 to 25 years, had 2 respondents (15.3\%), while none (0\%) of the respondents fell in the 26 plus years range for being in their current position. The newer directors of the females, those in the 1 to 5 year span $(n=9,40.9 \%)$ and 6 to 10 year span $(n=10,45.5 \%)$, comprised a majority of the respondents. The span for 11 to 15 years had two respondents (9.1\%). The fourth and sixth spans had no (0\%) responses, while one respondent (4.5\%) indicated being in the 21 to 25 year span. None (0\%) of the male respondents held only a Bachelors' degree, while the majority $(n=10,76.9 \%)$ had a Masters' and close to one-quarter (n $=3,23.1 \%$ ) held a Doctorate. As with their male counter parts, none $(0 \%)$ of the female respondents held only a Bachelors’ degree, while the majority ( $n=20,90.9 \%)$ had a Masters' and two (9.1\%) held a Doctorate. The vast majority of males $(n=12,92.3 \%)$ held an endorsement through a general administration program, while only one (7.7\%) had an 
endorsement through a program specifically designed for the administration of special education programs. The vast majority of females $(n=21,95.5 \%)$ held an endorsement through a general administration program, while only one (4.5\%) had an endorsement through a program specifically designed for the administration of special education programs. It is of note that of the 21 female respondents who held an endorsement through a general program, two (9.5\%) also held an endorsement through a special education program.

Of the state's two major universities, six male respondents (46.2\%) who held an endorsement attended West Virginia University, while 4 (30.7\%) attended Marshall University. Frostburg State, The College of Graduate Studies, and Virginia Polytechnic Institute and State University each had one attendee (7.7\%). None of the males (0\%) indicated their endorsement was from Salem University. Of the State's two major universities, nine female respondents (40.9\%) who held an endorsement attended Marshall University, while seven (31.8\%) attended West Virginia University. Three (13.7\%) attended The College of Graduate Studies, while two (9.1) attended Salem University, and one attended Virginia Polytechnic Institute and State University (4.5\%). None of the females (0\%) indicated their endorsement was from Frostburg State . The range in years that the male respondents received their endorsement was from 1972 to 2004 . Three (23.1\%) received their endorsement during the 1970's. The 1980s had five respondents (38.5\%) receive their endorsement. Another $23.1 \%(n=3)$ of the respondents received their endorsement during the 1990s, while two (15.3\%) received their endorsements during the 2000s. The range in years when the female respondents received their endorsement was from 1981 to 2005. The 1980s had three respondents (13.6\%) receive their endorsement. The 1990s had the largest group ( $\mathrm{n}=12,54.5 \%)$ of the respondents receive their endorsement, 
while seven (31.9\%) received their endorsements during the 2000s.

Special Education Director Preparation - All Respondents with an Endorsement.

Of the 35 respondents with an endorsement, only eight (22.9\%) indicated their graduate work did include role-playing that focused on problem solving special education issues. About two-thirds ( $n=22,62.9 \%$ ) of the same respondents indicated their course did offer an appropriate number of school law courses. Relatively few $(n=7,20 \%)$ of all respondents felt their program had an appropriate number of law courses dedicated specifically to special education legal issues. In response to a reverse order question, close to one-third of the respondents $(\mathrm{n}=10,28.5 \%)$ indicated their formal preparation did offer special education courses. Few respondents $(n=5,14.3 \%)$ felt they were prepared through their coursework to chair an IEP meeting. A vast majority $(n=31,88.6 \%)$ of the respondents felt specific coursework related to leadership skills was provided. Not quite half of the respondents $(\mathrm{n}=16$, 45.7\%) did agree they were adequately prepared for their current positions (see Table 9). Special Education Director Preparation - Males and Females.

Of the 13 male respondents, almost one-third $(n=4,30.8 \%)$ of the male respondents who had an administrative endorsement indicated their graduate work did include role-playing that focused on problem solving special education issues. Of the 22 female respondents, very few (n $=4,18.2 \%$ ) of the female respondents who had an administrative endorsement indicated their graduate work did include role-playing that focused on problem solving special education issues. Almost all $(\mathrm{n}=12,92.3 \%)$ of the male respondents indicated their course did offer an appropriate number of school law courses. Less than half $(n=10,45.4 \%)$ of the female respondents indicated their course did offer an appropriate number of school law courses. Less 
Table 9

Special Education Director Preparation All Respondents with Administrative Endorsement

Descriptor $\quad$ Subject Response

\begin{tabular}{|c|c|c|c|c|}
\hline & $\begin{array}{l}\text { Strongly } \\
\text { Agree }\end{array}$ & Agree & Disagree & $\begin{array}{l}\text { Strongly } \\
\text { Disagree }\end{array}$ \\
\hline $\begin{array}{l}\text { My graduate level administrative program included role- } \\
\text { playing that focused on problem solving special } \\
\text { education issues. }\end{array}$ & $\begin{array}{c}5 \\
(14.3 \%)\end{array}$ & $\begin{array}{l}3 \\
(8.6 \%)\end{array}$ & $\begin{array}{c}12 \\
(34.3 \%)\end{array}$ & $\begin{array}{c}15 \\
(42.8 \%)\end{array}$ \\
\hline $\begin{array}{l}\text { My administrative program provided an appropriate } \\
\text { number of school law courses. }\end{array}$ & $\begin{array}{c}10 \\
(28.6 \%)\end{array}$ & $\begin{array}{c}12 \\
(34.3 \%)\end{array}$ & $\begin{array}{c}9 \\
(25.7 \%)\end{array}$ & $\begin{array}{c}4 \\
(11.4 \%)\end{array}$ \\
\hline $\begin{array}{l}\text { My training program provided an appropriate number of } \\
\text { special education law courses. }\end{array}$ & $\begin{array}{c}1 \\
(2.9 \%)\end{array}$ & $\begin{array}{c}6 \\
(17.1 \%)\end{array}$ & $\begin{array}{c}10 \\
(28.6 \%)\end{array}$ & $\begin{array}{c}18 \\
(51.4 \%)\end{array}$ \\
\hline $\begin{array}{l}\text { My graduate level administrative program did not offer } \\
\text { any special education courses. }\end{array}$ & $\begin{array}{c}15 \\
(42.9 \%)\end{array}$ & $\begin{array}{c}10 \\
(28.6 \%)\end{array}$ & $\begin{array}{c}6 \\
(17.1 \%)\end{array}$ & $\begin{array}{c}4 \\
(11.4 \%)\end{array}$ \\
\hline $\begin{array}{l}\text { My graduate level administrative program prepared me to } \\
\text { chair an IEP meeting. }\end{array}$ & $\begin{array}{l}2 \\
(5.7 \%)\end{array}$ & $\begin{array}{l}3 \\
(8.6 \%)\end{array}$ & $\begin{array}{c}12 \\
(34.3 \%)\end{array}$ & $\begin{array}{c}18 \\
(51.4 \%)\end{array}$ \\
\hline $\begin{array}{l}\text { My administrative program provided specific course } \\
\text { work related to leadership skills. }\end{array}$ & $\begin{array}{c}17 \\
(48.6 \%)\end{array}$ & $\begin{array}{c}14 \\
(40.0 \%)\end{array}$ & $\begin{array}{l}2 \\
(5.7 \%)\end{array}$ & $\begin{array}{l}2 \\
(5.7 \%)\end{array}$ \\
\hline $\begin{array}{l}\text { My graduate level administrative program adequately } \\
\text { prepared me for my current position. }\end{array}$ & $\begin{array}{c}3 \\
(8.6 \%)\end{array}$ & $\begin{array}{c}13 \\
(37.1 \%)\end{array}$ & $\begin{array}{c}14 \\
(40.0 \%)\end{array}$ & $\begin{array}{c}5 \\
(14.3 \%)\end{array}$ \\
\hline
\end{tabular}

Note: Domain 1. Descriptors and subject responses for special education director preparation for all respondents with administrative endorsement. 
than one-fourth ( $\mathrm{n}=3,23.0 \%)$ the male respondents felt their program had an appropriate number of law courses dedicated specifically to special education legal issues. Few ( $n=4$, 18.2\%) of the female respondents felt their program had an appropriate number of law courses dedicated specifically to special education legal issues. In response to a reverse order question, very few $(n=2,15.4 \%)$ of the males indicated they felt special education courses were not offered during their coursework. Likewise in response to the same question, less than half ( $\mathrm{n}=$ 9, 39.9\%) of the females indicated that special education courses were not offered during their coursework. Again, very few male respondents $(n=2,15.4 \%)$ felt they were prepared through their coursework to chair an IEP meeting. Likewise, few female respondents $(n=3,13.6 \%)$ felt they were prepared through their coursework to chair an IEP meeting. All $(n=13,100 \%)$ of the male respondents felt specific coursework related to leadership skills was provided. A majority ( $\mathrm{n}=18,81.8 \%)$ of the female respondents agreed that specific coursework related to leadership skills was provided. Over all, a majority of the male respondents $(n=9,69.2 \%)$ did agree they were adequately prepared for their current positions while less than one-third of the female respondents ( $\mathrm{n}=7,31.8 \%)$ agreed (see Table 10$)$. Skills Learned On-The-Job-All Respondents with an Endorsement.

The five items presented in this domain addressed the directors' perceptions related to areas they felt were learned while carrying out the responsibilities of the position. A vast majority ( $n=34$, 97.2\%) of those with an endorsement indicated they acquired their ability to work with parents as valued members of the IEP process while on the job. A majority $(n=29,82.9 \%)$ of the respondents felt their ability to work with the increasing demands related to cultural diversity was acquired from on the job experiences. Close to three-fourths ( $n=26,74.3 \%)$ of the respondents, in response to a 


\section{Table 10}

\section{Special Education Director Preparation Male and Female Respondents with Administrative} Endorsement

\begin{tabular}{|c|c|c|c|c|}
\hline Descriptor & \multicolumn{4}{|c|}{ Subject Response } \\
\hline Males & $\begin{array}{l}\text { Strongly } \\
\text { Agree }\end{array}$ & Agree & Disagree & $\begin{array}{l}\text { Strongly } \\
\text { Disagree }\end{array}$ \\
\hline $\begin{array}{l}\text { My graduate level administrative program included role-playing that } \\
\text { focused on problem solving special education issues. }\end{array}$ & $\begin{array}{l}3 \\
(23.1 \%)\end{array}$ & $\begin{array}{c}1 \\
(7.7 \%)\end{array}$ & $\begin{array}{c}3 \\
(23.1 \%)\end{array}$ & $\begin{array}{c}6 \\
(46.1 \%)\end{array}$ \\
\hline $\begin{array}{l}\text { My administrative program provided an appropriate number of school } \\
\text { law courses. }\end{array}$ & $\begin{array}{c}5 \\
(38.5 \%)\end{array}$ & $\begin{array}{c}7 \\
(53.8 \%)\end{array}$ & $\begin{array}{l}1 \\
(7.7 \%)\end{array}$ & $\begin{array}{l}0 \\
(0.0 \%)\end{array}$ \\
\hline $\begin{array}{l}\text { My training program provided an appropriate number of special } \\
\text { education law courses. }\end{array}$ & $\begin{array}{c}0 \\
(0.0 \%)\end{array}$ & $\begin{array}{c}3 \\
(23.0 \%)\end{array}$ & $\begin{array}{c}5 \\
(38.5 \%)\end{array}$ & $\begin{array}{c}5 \\
(38.5 \%)\end{array}$ \\
\hline $\begin{array}{l}\text { My graduate level administrative program did not offer any special } \\
\text { education courses. }\end{array}$ & $\begin{array}{c}6 \\
(46.1 \%)\end{array}$ & $\begin{array}{c}5 \\
(38.5 \%)\end{array}$ & $\begin{array}{l}1 \\
(7.7 \%)\end{array}$ & $\begin{array}{l}1 \\
(7.7 \%)\end{array}$ \\
\hline $\begin{array}{l}\text { My graduate level administrative program prepared me to chair an IEP } \\
\text { meeting. }\end{array}$ & $(7.7 \%)$ & $(7.7 \%)$ & $\begin{array}{c}6 \\
(46.1 \%)\end{array}$ & $\begin{array}{c}5 \\
(38.5 \%)\end{array}$ \\
\hline $\begin{array}{l}\text { My administrative program provided specific course work related to } \\
\text { leadership skills. }\end{array}$ & $\begin{array}{c}8 \\
(61.5 \%)\end{array}$ & $\begin{array}{c}5 \\
(38.5 \%)\end{array}$ & $\begin{array}{c}0 \\
(0.0 \%)\end{array}$ & $\begin{array}{c}0 \\
(0.0 \%)\end{array}$ \\
\hline $\begin{array}{l}\text { My graduate level administrative program adequately prepared me for } \\
\text { my current position. }\end{array}$ & $\begin{array}{l}2 \\
(15.4 \%)\end{array}$ & $\begin{array}{c}7 \\
(53.8 \%)\end{array}$ & $\begin{array}{c}4 \\
(30.8 \%)\end{array}$ & $\begin{array}{c}0 \\
(0.0 \%)\end{array}$ \\
\hline \multicolumn{5}{|l|}{ Females } \\
\hline $\begin{array}{l}\text { My graduate level administrative program included role-playing that } \\
\text { focused on problem solving special education issues. }\end{array}$ & $\begin{array}{l}2 \\
(9.1 \%)\end{array}$ & $\begin{array}{l}2 \\
(9.1 \%)\end{array}$ & $\begin{array}{c}9 \\
(40.9 \%)\end{array}$ & $\begin{array}{c}9 \\
(40.9 \%)\end{array}$ \\
\hline $\begin{array}{l}\text { My administrative program provided an appropriate number of school } \\
\text { law courses. }\end{array}$ & $\begin{array}{c}5 \\
(22.7 \%)\end{array}$ & $\begin{array}{c}5 \\
(22.7 \%)\end{array}$ & $\begin{array}{c}8 \\
(36.4 \%)\end{array}$ & $\begin{array}{c}4 \\
(18.2 \%)\end{array}$ \\
\hline $\begin{array}{l}\text { My training program provided an appropriate number of special } \\
\text { education law courses. }\end{array}$ & $\begin{array}{l}1 \\
(4.5 \%)\end{array}$ & $\begin{array}{c}3 \\
(13.7 \%)\end{array}$ & $\begin{array}{l}5 \\
(22.7 \%)\end{array}$ & $\begin{array}{c}13 \\
(59.1 \%)\end{array}$ \\
\hline $\begin{array}{l}\text { My graduate level administrative program did not offer any special } \\
\text { education courses. }\end{array}$ & $\begin{array}{c}8 \\
(36.4 \%)\end{array}$ & $\begin{array}{c}5 \\
(22.7 \%)\end{array}$ & $\begin{array}{c}6 \\
(27.3 \%)\end{array}$ & $\begin{array}{c}3 \\
(13.6 \%)\end{array}$ \\
\hline $\begin{array}{l}\text { My graduate level administrative program prepared me to chair an IEP } \\
\text { meeting. }\end{array}$ & $\begin{array}{l}1 \\
(4.5 \%)\end{array}$ & $\begin{array}{l}2 \\
(9.1 \%)\end{array}$ & $\begin{array}{c}6 \\
(27.3 \%)\end{array}$ & $\begin{array}{c}13 \\
(59.1 \%)\end{array}$ \\
\hline $\begin{array}{l}\text { My administrative program provided specific course work related to } \\
\text { leadership skills. }\end{array}$ & $\begin{array}{c}9 \\
(40.9 \%)\end{array}$ & $\begin{array}{c}9 \\
(40.9 \%)\end{array}$ & $\begin{array}{l}2 \\
(9.1 \%)\end{array}$ & $\begin{array}{l}2 \\
(9.1 \%)\end{array}$ \\
\hline $\begin{array}{l}\text { My graduate level administrative program adequately prepared me for } \\
\text { my current position. }\end{array}$ & $\begin{array}{c}1 \\
(4.5 \%)\end{array}$ & $\begin{array}{c}6 \\
(27.3 \%)\end{array}$ & $\begin{array}{c}10 \\
(45.5 \%)\end{array}$ & $\begin{array}{c}5 \\
(22.7 \%)\end{array}$ \\
\hline
\end{tabular}

Note: Domain 1. Descriptors and subject response for special education director preparation for male and female respondents. 
reverse order question, indicated they did learn how to develop and implement a budget to address the needs of students with disabilities while in their position. A vast majority $(n=32,91.5 \%)$ of the respondents did indicate their ability to effectively communicate federal and state policy related to special needs students was acquired while in their current position. Most $(n=31,88.6 \%)$ of the respondents indicated the on-the-job experiences were more helpful to them related to the responsibilities of their current position than their coursework was (see Table 11). Skills Learned on the Job-All Male and Female Respondents.

All ( $\mathrm{n}=13,100 \%)$ of the male respondents indicated they acquired their ability to work with parents as valued members of the IEP process while on the job. Almost all $(n=21,95.5 \%)$ of the female respondents indicated they acquired their ability to work with parents as valued members of the IEP process while on the job. Almost all $(n=12,92.3 \%)$ of the male respondents felt their ability to work with the increasing demands related to cultural diversity was acquired from on-the-job experiences. Over three-fourths $(n=17,77.3 \%)$ of the female respondents felt their ability to work with the increasing demands related to cultural diversity was acquired from on-the-job experiences. A majority $(n=8,61.5 \%)$ of the males, in responding to a reverse order question, indicated they did learn while in their current position how to develop and implement a budget to address the needs of students with disabilities. A majority $(\mathrm{n}=18,81.9 \%)$ of the females likewise responded to the same reverse order questions that they did learn while in their current position how to develop and implement a budget to address the needs of students with disabilities. Almost all $(\mathrm{n}=12,92.3 \%)$ of the male respondents did indicate their ability to effectively communicate federal and state policy related to special needs students was acquired while in their current position. A vast majority ( $\mathrm{n}=20$, 
Table 11

Skills Learned on the Job All Respondents with Administrative Endorsement

\begin{tabular}{|c|c|c|c|c|}
\hline \multirow[t]{2}{*}{ Descriptor } & \multicolumn{4}{|c|}{ Subject Response } \\
\hline & $\begin{array}{l}\text { Strongly } \\
\text { Agree }\end{array}$ & Agree & Disagree & $\begin{array}{l}\text { Strongly } \\
\text { Disagree }\end{array}$ \\
\hline $\begin{array}{l}\text { My ability to work with parents as valued members of the } \\
\text { IEP process was a skill developed on the job. }\end{array}$ & $\begin{array}{c}24 \\
(68.6 \%)\end{array}$ & $\begin{array}{c}10 \\
(28.6 \%)\end{array}$ & $\begin{array}{c}0 \\
(0.0 \%)\end{array}$ & $\begin{array}{c}1 \\
(2.8 \%)\end{array}$ \\
\hline $\begin{array}{l}\text { My current position offers me the opportunity to enhance } \\
\text { my ability to work with the increasing concerns related to } \\
\text { the cultural diversity of students with disabilities. }\end{array}$ & $\begin{array}{c}16 \\
(45.7 \%)\end{array}$ & $\begin{array}{c}13 \\
(37.2 \%)\end{array}$ & $\begin{array}{c}5 \\
(14.3 \%)\end{array}$ & $\begin{array}{c}1 \\
(2.8 \%)\end{array}$ \\
\hline $\begin{array}{l}\text { My ability to develop and implement a budget to address } \\
\text { the needs of students with disabilities was not acquired } \\
\text { on the job. }\end{array}$ & $\begin{array}{c}2 \\
(5.7 \%)\end{array}$ & $\begin{array}{c}7 \\
(20.0 \%)\end{array}$ & $\begin{array}{c}11 \\
(31.4 \%)\end{array}$ & $\begin{array}{c}15 \\
(42.9 \%)\end{array}$ \\
\hline $\begin{array}{l}\text { My ability to effectively communicate federal and state } \\
\text { policy related to the delivery of special education services } \\
\text { was a skill developed while in my current position. }\end{array}$ & $\begin{array}{c}17 \\
(48.6 \%)\end{array}$ & $\begin{array}{c}15 \\
(42.9 \%)\end{array}$ & $\begin{array}{c}3 \\
(8.5 \%)\end{array}$ & $\begin{array}{c}0 \\
(0.0 \%)\end{array}$ \\
\hline $\begin{array}{l}\text { My on the job experiences have been more helpful with } \\
\text { my job related responsibilities than my coursework. }\end{array}$ & $\begin{array}{c}22 \\
(62.9 \%)\end{array}$ & $\begin{array}{c}9 \\
(25.7 \%)\end{array}$ & $\begin{array}{c}4 \\
(11.4 \%)\end{array}$ & $\begin{array}{c}0 \\
(0.0 \%)\end{array}$ \\
\hline
\end{tabular}

Note: Domain 2. Descriptors and subject responses for skills learned on the job for all respondents with administrative endorsement. 
90.9\%) of the female respondents did indicate their ability to effectively communicate federal and state policy related to special needs students was acquired while in their current position. An overwhelming majority ( $\mathrm{n}=12,92.3 \%)$ of the males indicated the on-the-job experiences were more helpful to them related to the responsibilities of their current position than their coursework was. A majority ( $\mathrm{n}=19,86.4 \%$ ) of the females indicated the on-the-job experiences were more helpful to them related to the responsibilities of their current position than their coursework was (see Table 12).

Building a Better Education Administration Program - All Respondents with an Endorsement. The final domain consisted of six questions seeking the respondents’ perceptions of building a better education administration program related to special education. Almost all $(\mathrm{n}=$ 34, 97.1\%) of the respondents felt administrative internships should include a unit focusing on the administration of programs for students with disabilities. A vast majority of respondents (n $=33,94.3 \%$ ) indicated all education administration programs should require at least one special education law course and one general school law course. Most of the respondents $(n=27$, 77.2\%) felt graduate level education administration programs should include role playing that focused on problem solving special education issues. Several $(n=26,74.3 \%)$ indicated they favored education administration programs including nine hours of special education course work. In response to a reverse order question, a majority $(n=32,91.4 \%)$ felt course work devoted to leadership skills was needed in graduate level education administration programs. Fewer than half ( $\mathrm{n}=16,45.7 \%)$ of the respondents indicated West Virginia should require a specific administration endorsement for directors of special education (see Table 13). 


\section{Table 12}

\section{Skills Learned on the Job Male and Female Respondents with Administrative Endorsement}

\section{Descriptor}

\section{Subject Response}

\section{Males}

My ability to work with parents as valued members of the IEP process was a skill developed on the job.

My current position offers me the opportunity to enhance my ability to work with the increasing concerns related to the cultural diversity of students with disabilities.

My ability to develop and implement a budget to address the needs of students with disabilities was not acquired on the job.

My ability to effectively communicate federal and state policy related to the delivery of special education services was a skill developed while in my current position.

My on the job experiences have been more helpful with my job related responsibilities than my coursework.

\section{Females}

My ability to work with parents as valued members of the IEP process was a skill developed on the job.

My current position offers me the opportunity to enhance my ability to work with the increasing concerns related to the cultural diversity of students with disabilities.

My ability to develop and implement a budget to address the needs of students with disabilities was not acquired on the job.

My ability to effectively communicate federal and state policy related to the delivery of special education services was a skill developed while in my current position.

My on the job experiences have been more helpful with my job related responsibilities than my coursework.
Strongly
Agree

Agree

Disagree

Strongly

9

$(69.2 \%)$

7

$(53.8 \%)$

4

0

Disagree

\begin{tabular}{cccc}
1 & 4 & 3 & 5 \\
$(7.7 \%)$ & $(30.8 \%)$ & $(23.1 \%)$ & $(38.4 \%)$ \\
8 & 4 & 1 & 0 \\
$(61.5 \%)$ & $(30.8 \%)$ & $(7.7 \%)$ & $(0.0 \%)$ \\
& & & \\
9 & 3 & 1 & 0 \\
$(69.2 \%)$ & $(23.1 \%)$ & $(7.7 \%)$ & $(0.0 \%)$ \\
& & & \\
15 & 6 & 0 & 1 \\
$(68.2 \%)$ & $(27.3 \%)$ & $(0.0 \%)$ & $(4.5 \%)$ \\
9 & 8 & 4 & 1 \\
$(40.9 \%)$ & $(36.4 \%)$ & $(18.2 \%)$ & $(4.5 \%)$ \\
\multicolumn{5}{c}{} & & \\
1 & 3 & 8 & 10 \\
$(4.5 \%)$ & $(13.6 \%)$ & $(36.4 \%)$ & $(45.5 \%)$ \\
9 & 11 & 2 & 0 \\
$(40.9 \%)$ & $(50.0 \%)$ & $(9.1 \%)$ & $(0.0 \%)$ \\
13 & & & \\
$(59.1 \%)$ & $(27.3 \%)$ & $(13.6 \%)$ & $(0.0 \%)$
\end{tabular}

$(30.8 \%)$

0
$0.0 \%)$

$\begin{array}{ccc}5 & 1 & 0 \\ (38.5 \%) & (7.7 \%) & (0.0 \%)\end{array}$

$(0.0 \%)$

\section{5}

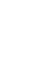


Building a Better Education Administration Program - All Male and Female Respondents with an Endorsement.

Almost all ( $\mathrm{n}=12,92.3 \%)$ of the male respondents felt administrative internships should include a unit focusing on the administration of programs for students with disabilities. All $(\mathrm{n}=$ 22, 100\%) of the female respondents felt administrative internships should include a unit focusing on the administration of programs for students with disabilities. A majority of males ( $\mathrm{n}=11,84.7 \%)$ indicated all education administration programs should require at least one special education law course and one general school law course. All of females ( $\mathrm{n}=22,100 \%)$ indicated all education administration programs should require at least one special education law course and one general school law course. A majority of the males $(n=9,69.2 \%)$ felt graduate level education administration programs should include role playing that focused on problem solving special education issues. A majority of the females $(n=18,81.8 \%)$ felt graduate level education administration programs should include role playing that focused on problem solving special education issues. Less than half $(n=6,46.2 \%)$ of the males favored education administration programs including nine hours of special education course work. A vast majority ( $n=20,90.9 \%$ ) of the females favored education administration programs including nine hours of special education course work. In response to a reverse order question, all ( $\mathrm{n}=13,100 \%)$ of the males and a majority ( $\mathrm{n}=19,86.4 \%)$ of the females felt course work devoted to leadership skills was needed in graduate level education administration programs. Less than one-fourth (n $=3,23.1 \%$ ) of the males indicated West Virginia should require a specific administration endorsement for directors of special education. A higher proportion ( $n=13,59.1 \%)$ of the females indicated the state should require a specific administration endorsement for directors of 


\section{Table 13}

Building a Better Education Administration Program All Respondents with Administrative Endorsement

\begin{tabular}{|c|c|c|c|c|}
\hline & $\begin{array}{l}\text { Strongly } \\
\text { Agree }\end{array}$ & Agree & Disagree & $\begin{array}{l}\text { Strongly } \\
\text { Disagree }\end{array}$ \\
\hline $\begin{array}{l}\text { Administrative internships should include a unit that } \\
\text { focuses on the administration of programs for students } \\
\text { with disabilities. }\end{array}$ & $\begin{array}{c}24 \\
(68.6 \%)\end{array}$ & $\begin{array}{c}10 \\
(28.6 \%)\end{array}$ & $\begin{array}{c}0 \\
(0.0 \%)\end{array}$ & $\begin{array}{c}1 \\
(2.8 \%)\end{array}$ \\
\hline $\begin{array}{l}\text { All education administration programs should require at } \\
\text { least one special education law course and one general } \\
\text { school law course. }\end{array}$ & $\begin{array}{c}22 \\
(62.9 \%)\end{array}$ & $\begin{array}{c}11 \\
(31.4 \%)\end{array}$ & $\begin{array}{l}2 \\
(5.7 \%)\end{array}$ & $\begin{array}{c}0 \\
(0.0 \%)\end{array}$ \\
\hline $\begin{array}{l}\text { Graduate level education administration programs should } \\
\text { include role playing that focuses on problem solving } \\
\text { special education issues. }\end{array}$ & $\begin{array}{c}12 \\
(34.3 \%)\end{array}$ & $\begin{array}{c}15 \\
(42.9 \%)\end{array}$ & $\begin{array}{c}6 \\
(17.1 \%)\end{array}$ & $\begin{array}{l}2 \\
(5.7 \%)\end{array}$ \\
\hline $\begin{array}{l}\text { Graduate level education administration programs should } \\
\text { include } 9 \text { hours of special education course work. }\end{array}$ & $\begin{array}{c}8 \\
(22.9 \%)\end{array}$ & $\begin{array}{c}18 \\
(51.4 \%)\end{array}$ & $\begin{array}{c}6 \\
(17.1 \%)\end{array}$ & $\begin{array}{l}3 \\
(8.5 \%)\end{array}$ \\
\hline $\begin{array}{l}\text { Course work devoted to leadership skills is not needed in } \\
\text { graduate level education administration programs. }\end{array}$ & $\begin{array}{l}2 \\
(5.7 \%)\end{array}$ & $\begin{array}{c}1 \\
(2.8 \%)\end{array}$ & $\begin{array}{c}8 \\
(22.9 \%)\end{array}$ & $\begin{array}{c}24 \\
(68.6 \%)\end{array}$ \\
\hline $\begin{array}{l}\text { West Virginia should require a specific administration } \\
\text { endorsement for directors of special education. }\end{array}$ & $\begin{array}{c}5 \\
(14.3 \%)\end{array}$ & $\begin{array}{c}11 \\
(31.4 \%)\end{array}$ & $\begin{array}{c}9 \\
(25.7 \%)\end{array}$ & $\begin{array}{c}10 \\
(28.6 \%)\end{array}$ \\
\hline
\end{tabular}

Note: Domain 3. Descriptors and subject response for building a better education administration program for all respondents with administrative endorsement. 
for directors of special education (see Table 14).

\author{
Without an Endorsement
}

\title{
Demographics.
}

Of the 45 respondents, 10 (22.2\%) indicated they currently did not hold an administrative endorsement for either general education or special education programs. A majority $(\mathrm{n}=8$, $80 \%$ ) of the respondents in the sub set indicated they had taught in a public school special education classroom. Related to the years of experience the respondents had in their current position, the respondents were evenly divided in terms of newer directors ( $n=5,50 \%)$, those in the 1 to 5 years $(n=4,40 \%)$ and 6 to $10(n=1,10 \%)$ year ranges, and older directors $(n=5$, 50\%), those in the 11 to $15(\mathrm{n}=2,20 \%), 16$ to $20(\mathrm{n}=1,10 \%), 21$ to $25(\mathrm{n}=0,0 \%)$, and the 26 plus years ( $n=2,20 \%)$ ranges. It does need notice that for all the respondents to the survey, two current directors without an endorsement were the only participants in the 26 plus year range. All 10 (100\%) of the respondents indicated having a Masters’ degree. Demographics - Males and Females without an Endorsement.

Of the 10 respondents without an endorsement, five (50\%) were male and five were female (50\%). Of the five males, three-fifths $(n=3,60 \%)$ had taught in a public school special education classroom. All five female (100\%) respondents had taught in a public school special education classroom. Only one male (20\%) respondent had been in the position for less than 10 years falling into the 1 to 5 years range. There were no (0\%) respondents in the 6 to 10 years range. Two respondents (40\%) indicated they had been in their current position from 11 to 15 years. Only one respondent (20\%) indicated being the position from 16 to 20 years. As with 6 to 10 years range, there were no $(0 \%)$ respondents in the 21 to 25 years range. One male 


\section{Table 14}

\section{Building a Better Education Administration Program Male and Female Respondents with Administrative Endorsement}

Descriptor

\section{Males}

Administrative internships should include a unit that focuses on the administration of programs for students with disabilities.

All education administration programs should require at least one special education law course and one general school law course.

Graduate level education administration programs should include role playing that focuses on problem solving special education issues.

Graduate level education administration programs should include 9 hours of special education course work.

Course work devoted to leadership skills is not needed in graduate level education administration programs.

West Virginia should require a specific administration endorsement for directors of special education.

\section{Females}

Administrative internships should include a unit that focuses on the administration of programs for students with disabilities.

All education administration programs should require at least one special education law course and one general school law course.

Graduate level education administration programs should include role playing that focuses on problem solving special education issues.

Graduate level education administration programs should include 9 hours of special education course work.

Course work devoted to leadership skills is not needed in graduate level education administration programs.

West Virginia should require a specific administration endorsement for directors of special education.
Subject Response

\begin{tabular}{|c|c|c|c|}
\hline $\begin{array}{l}\text { Strongly } \\
\text { Agree }\end{array}$ & Agree & Disagree & $\begin{array}{l}\text { Strongly } \\
\text { Disagree }\end{array}$ \\
\hline $\begin{array}{c}7 \\
(53.8 \%)\end{array}$ & $\begin{array}{c}5 \\
(38.5 \%)\end{array}$ & $\begin{array}{c}0 \\
(0.0 \%)\end{array}$ & $\begin{array}{c}1 \\
(7.7 \%)\end{array}$ \\
\hline $\begin{array}{c}5 \\
(38.5 \%)\end{array}$ & $\begin{array}{c}6 \\
(46.2 \%)\end{array}$ & $\begin{array}{c}2 \\
(15.3 \%)\end{array}$ & $\begin{array}{c}0 \\
(0.0 \%)\end{array}$ \\
\hline $\begin{array}{c}5 \\
(38.5 \%)\end{array}$ & $\begin{array}{c}4 \\
(30.7 \%)\end{array}$ & $\begin{array}{c}3 \\
(23.1 \%)\end{array}$ & $\begin{array}{c}1 \\
(7.7 \%)\end{array}$ \\
\hline $\begin{array}{c}1 \\
(7.7 \%)\end{array}$ & $\begin{array}{c}5 \\
(38.5 \%)\end{array}$ & $\begin{array}{c}4 \\
(30.7 \%)\end{array}$ & $\begin{array}{c}3 \\
(23.1 \%)\end{array}$ \\
\hline $\begin{array}{c}0 \\
(0.0 \%)\end{array}$ & $\begin{array}{c}0 \\
(0.0 \%)\end{array}$ & $\begin{array}{c}4 \\
(30.7 \%)\end{array}$ & $\begin{array}{c}9 \\
(69.3 \%)\end{array}$ \\
\hline $\begin{array}{c}1 \\
(7.7 \%)\end{array}$ & $\begin{array}{c}2 \\
(15.4 \%)\end{array}$ & $\begin{array}{c}6 \\
(46.2 \%)\end{array}$ & $\begin{array}{c}4 \\
(30.7 \%)\end{array}$ \\
\hline $\begin{array}{c}17 \\
(77.3 \%)\end{array}$ & $\begin{array}{c}5 \\
(22.7 \%)\end{array}$ & $\begin{array}{c}0 \\
(0.0 \%)\end{array}$ & $\begin{array}{c}0 \\
(0.0 \%)\end{array}$ \\
\hline $\begin{array}{c}17 \\
(77.3 \%)\end{array}$ & $\begin{array}{c}5 \\
(22.7 \%)\end{array}$ & $\begin{array}{c}0 \\
(0.0 \%)\end{array}$ & $\begin{array}{c}0 \\
(0.0 \%)\end{array}$ \\
\hline $\begin{array}{c}7 \\
(31.8 \%)\end{array}$ & $\begin{array}{c}11 \\
(50.0 \%)\end{array}$ & $\begin{array}{c}3 \\
(13.7 \%)\end{array}$ & $\begin{array}{c}1 \\
(4.5 \%)\end{array}$ \\
\hline $\begin{array}{c}7 \\
(31.8 \%)\end{array}$ & $\begin{array}{c}13 \\
(59.1 \%)\end{array}$ & $\begin{array}{c}2 \\
(9.1 \%)\end{array}$ & $\begin{array}{c}0 \\
(0.0 \%)\end{array}$ \\
\hline $\begin{array}{c}2 \\
(9.1 \%)\end{array}$ & $\begin{array}{c}1 \\
(4.5 \%)\end{array}$ & $\begin{array}{c}4 \\
(18.2 \%)\end{array}$ & $\begin{array}{c}15 \\
(68.2 \%\end{array}$ \\
\hline $\begin{array}{c}4 \\
8.2\end{array}$ & $\begin{array}{c}9 \\
\left(40.9^{\circ}\right.\end{array}$ & $\begin{array}{c}3 \\
(13.7 \%)\end{array}$ & $\begin{array}{c}6 \\
\left(27.2^{\circ}\right.\end{array}$ \\
\hline
\end{tabular}

Note: Domain 3. Descriptors and subject response for building a better education administration program for all male and female respondents. 
respondent (20\%) fell in the 26 plus years range. The majority of the females $(n=4,80 \%)$ indicated having been in the position for less than 10 years, three $(60 \%)$ in the 1 to 5 years range and one (20\%) in the 6 to 10 years range. There were no respondents ( $0 \%)$ in the 11 to 15,16 to 20 or the 21 to 25 years spans. One female respondent (20\%) fell in the 26 plus years range. All five males (100\%) indicated they held a Master's degree as did all five females (100\%). Skills Learned on the Job-All Respondents.

The five items presented in this domain addressed the directors’ perceptions related to areas they felt were learned while carrying out the responsibilities of the position. All ( $\mathrm{n}=10$, $100 \%$ ) of the respondents indicated they acquired their ability to work with parents as valued members of the IEP process while on the job. Almost all $(n=9,90 \%)$ of the respondents felt their ability to work with the increasing demands related to cultural diversity was acquired from on-the-job experiences. A majority $(n=7,70 \%)$ of the respondents, when responding to a reverse order question, indicated they did learn how to develop and implement a budget to address the needs of students with disabilities while in their position. All ( $n=10,100 \%)$ of the respondents did indicate their ability to effectively communicate federal and state policy related to special needs students was acquired while in their current position. Almost all (n=9, 90\%) of the respondents indicated the on-the-job experiences were more helpful to them related to the responsibilities of their current position than their coursework was (see Table 15). Skills Learned on the Job-All Male and Female Respondents.

All $(n=5,100 \%)$ of the male respondents indicated they acquired their ability to work with parents as valued members of the IEP process while on the job. All ( $n=10,100 \%)$ of the female respondents indicated they acquired their ability to work with parents as valued members 
Table 15

Skills Learned on the Job All Respondents without Administrative Endorsement

Domain
Subject Response

\begin{tabular}{|c|c|c|c|c|}
\hline & $\begin{array}{l}\text { Strongly } \\
\text { Agree }\end{array}$ & Agree & Disagree & $\begin{array}{l}\text { Strongly } \\
\text { Disagree }\end{array}$ \\
\hline $\begin{array}{l}\text { My ability to work with parents as valued members of the } \\
\text { IEP process was a skill developed on the job. }\end{array}$ & $\begin{array}{c}8 \\
(80.0 \%)\end{array}$ & $\begin{array}{c}2 \\
(20.0 \%)\end{array}$ & $\begin{array}{c}0 \\
(0.0 \%)\end{array}$ & $\begin{array}{c}0 \\
(0.0 \%)\end{array}$ \\
\hline $\begin{array}{l}\text { My current position offers me the opportunity to enhance } \\
\text { my ability to work with the increasing concerns related to } \\
\text { the cultural diversity of students with disabilities. }\end{array}$ & $\begin{array}{c}5 \\
(50.0 \%)\end{array}$ & $\begin{array}{c}4 \\
(40.0 \%)\end{array}$ & $\begin{array}{c}1 \\
(10.0 \%)\end{array}$ & $\begin{array}{c}0 \\
(0.0 \%)\end{array}$ \\
\hline $\begin{array}{l}\text { My ability to develop and implement a budget to address } \\
\text { the needs of students with disabilities was not acquired } \\
\text { on the job. }\end{array}$ & $\begin{array}{c}1 \\
(10.0 \%)\end{array}$ & $\begin{array}{c}2 \\
(20.0 \%)\end{array}$ & $\begin{array}{c}2 \\
(20.0 \%)\end{array}$ & $\begin{array}{c}5 \\
(50.0 \%)\end{array}$ \\
\hline $\begin{array}{l}\text { My ability to effectively communicate federal and state } \\
\text { policy related to the delivery of special education services } \\
\text { was a skill developed while in my current position. }\end{array}$ & $\begin{array}{c}5 \\
(50.0 \%)\end{array}$ & $\begin{array}{c}5 \\
(50.0 \%)\end{array}$ & $\begin{array}{c}0 \\
(0.0 \%)\end{array}$ & $\begin{array}{c}0 \\
(0.0 \%)\end{array}$ \\
\hline $\begin{array}{l}\text { My on the job experiences have been more helpful with } \\
\text { my job related responsibilities than my coursework. }\end{array}$ & $\begin{array}{c}8 \\
(80.0 \%)\end{array}$ & $\begin{array}{c}1 \\
(10.0 \%)\end{array}$ & $\begin{array}{c}1 \\
(10.0 \%)\end{array}$ & $\begin{array}{c}0 \\
(0.0 \%)\end{array}$ \\
\hline
\end{tabular}

Note: Domain 2. Descriptors and subject response for skills learned on the job for all respondents without administrative endorsement. 
of the IEP process while on the job. All $(n=5,100 \%)$ of the male respondents felt their ability to work with the increasing demands related to cultural diversity was acquired from on-the-job experiences. Almost all ( $n=4,80 \%)$ of the female respondents felt their ability to work with the increasing demands related to cultural diversity was acquired from on the job experiences. In responding to a reverse order questions, almost all $(n=4,80 \%)$ of the male and a majority $(n=$ 3, 60\%) of female respondents indicated they did learn while in their current position how to develop and implement a budget to address the needs of students with disabilities. All ( $\mathrm{n}=5$, $100 \%$ ) of the male respondents did indicate their ability to effectively communicate federal and state policy related to special needs students was acquired while in their current position. All $(\mathrm{n}=$ 5, 100\%) of the female respondents did indicate their ability to effectively communicate federal and state policy related to special needs students was acquired while in their current position. All $(n=5,100 \%)$ of the male respondents indicated the on-the-job experiences were more helpful to them related to the responsibilities of their current position than their coursework was. Almost all ( $n=4,80 \%)$ of the female respondents indicated the on-the-job experiences were more helpful to them related to the responsibilities of their current position than their coursework was (see Table 16).

\section{Building a Better Education Administration Program-All Respondents.}

The final domain consisted of six questions seeking the respondents perceptions of building a better education administration program related to special education. Of the 10 respondents without an endorsement, almost all $(n=9,90 \%)$ of the respondents felt administrative internships should include a unit focusing on the administration of programs for students with disabilities. All $(\mathrm{n}=10,100 \%)$ indicated all education administration programs 


\section{Table 16}

\section{Skills Learned on the Job Male and Female Respondents without Administrative Endorsement}

\section{Descriptor}

Subject Response

\section{Males}

My ability to work with parents as valued members of the IEP process was a skill developed on the job.

My current position offers me the opportunity to enhance my ability to work with the increasing concerns related to the cultural diversity of students with disabilities.

My ability to develop and implement a budget to address the needs of students with disabilities was not acquired on the job.

My ability to effectively communicate federal and state policy related to the delivery of special education services was a skill developed while in my current position.

My on the job experiences have been more helpful with my job related responsibilities than my coursework.

\section{Females}

My ability to work with parents as valued members of the IEP process was a skill developed on the job.

My current position offers me the opportunity to enhance my ability to work with the increasing concerns related to the cultural diversity of students with disabilities.

My ability to develop and implement a budget to address the needs of students with disabilities was not acquired on the job.

My ability to effectively communicate federal and state policy related to the delivery of special education services was a skill developed while in my current position.

My on the job experiences have been more helpful with my job related responsibilities than my coursework.

\begin{tabular}{|c|c|c|c|}
\hline $\begin{array}{l}\text { Strongly } \\
\text { Agree }\end{array}$ & Agree & Disagree & $\begin{array}{l}\text { Strongly } \\
\text { Disagree }\end{array}$ \\
\hline $\begin{array}{c}3 \\
(60.0 \%)\end{array}$ & $\begin{array}{c}2 \\
(40.0 \%)\end{array}$ & $\begin{array}{c}0 \\
(0.0 \%)\end{array}$ & $\begin{array}{c}0 \\
(0.0 \%)\end{array}$ \\
\hline $\begin{array}{c}3 \\
(60.0 \%)\end{array}$ & $\begin{array}{c}2 \\
(40.0 \%)\end{array}$ & $\begin{array}{c}0 \\
(0.0 \%)\end{array}$ & $\begin{array}{c}0 \\
(0.0 \%)\end{array}$ \\
\hline $\begin{array}{c}0 \\
(0.0 \%)\end{array}$ & $\begin{array}{c}1 \\
(20.0 \%)\end{array}$ & $\begin{array}{c}1 \\
(20.0 \%)\end{array}$ & $\begin{array}{c}3 \\
(60.0 \%)\end{array}$ \\
\hline $\begin{array}{c}1 \\
(20.0 \%)\end{array}$ & $\begin{array}{c}4 \\
(80.0 \%)\end{array}$ & $\begin{array}{c}0 \\
(0.0 \%)\end{array}$ & $\begin{array}{c}0 \\
(0.0 \%)\end{array}$ \\
\hline $\begin{array}{c}5 \\
(100 \%)\end{array}$ & $\begin{array}{c}0 \\
(0.0 \%)\end{array}$ & $\begin{array}{c}0 \\
(0.0 \%)\end{array}$ & $\begin{array}{c}0 \\
(0.0 \%)\end{array}$ \\
\hline $\begin{array}{c}5 \\
(100 \%)\end{array}$ & $\begin{array}{c}0 \\
(0.0 \%)\end{array}$ & $\begin{array}{c}0 \\
(0.0 \%)\end{array}$ & $\begin{array}{c}0 \\
(0.0 \%)\end{array}$ \\
\hline $\begin{array}{c}2 \\
(40.0 \%)\end{array}$ & $\begin{array}{c}2 \\
(40.0 \%)\end{array}$ & $\begin{array}{c}1 \\
(20.0 \%)\end{array}$ & $\begin{array}{c}0 \\
(0.0 \%)\end{array}$ \\
\hline $\begin{array}{c}1 \\
(20.0 \%)\end{array}$ & $\begin{array}{c}1 \\
(20.0 \%)\end{array}$ & $\begin{array}{c}1 \\
(20.0 \%)\end{array}$ & $\begin{array}{c}2 \\
(40.0 \%)\end{array}$ \\
\hline $\begin{array}{c}4 \\
(80.0 \%)\end{array}$ & $\begin{array}{c}1 \\
(20.0 \%)\end{array}$ & $\begin{array}{c}0 \\
(0.0 \%)\end{array}$ & $\begin{array}{c}0 \\
(0.0 \%)\end{array}$ \\
\hline $\begin{array}{c}3 \\
(60.0 \%)\end{array}$ & $\begin{array}{c}1 \\
(20.0 \%)\end{array}$ & $\begin{array}{c}1 \\
(20.0 \%)\end{array}$ & $\begin{array}{c}0 \\
(0.0 \%)\end{array}$ \\
\hline
\end{tabular}

Note: Domain 2. Descriptors and subject response for skills learned on the job for all

male and female respondents without administrative endorsement. 
should require at least one special education law course and one general school law course. All ( $n=10,100 \%$ ) felt graduate level education administration programs should include role playing that focused on problem solving special education issues. A majority ( $n=8,80 \%$ ) of the respondents indicated they favored education administration programs including nine hours of special education course work. In response to a reverse order question, a majority $(n=7,70 \%)$ of the respondents felt course work devoted to leadership skills was needed in graduate level education administration programs. Less than half $(n=3,30 \%)$ of the respondents indicated West Virginia should require a specific administration endorsement for directors of special education (see Table 17).

Building a Better Education Administration Program - Male and Female Respondents.

All ( $n=5,100 \%)$ of the male respondents felt administrative internships should include a unit focusing on the administration of programs for students with disabilities. Almost all $(\mathrm{n}=4$, $80 \%$ ) of the female respondents felt administrative internships should include a unit focusing on the administration of programs for students with disabilities. All of the male respondents $(\mathrm{n}=5$, 100\%) indicated all education administration programs should require at least one special education law course and one general school law course. All of the female respondents $(\mathrm{n}=5$, 100\%) indicated all education administration programs should require at least one special education law course and one general school law course. All of the male respondents $(n=5$, 100\%) felt graduate level education administration programs should include role playing that focused on problem solving special education issues. All of the female $(n=5,100 \%)$ felt graduate level education administration programs should include role playing that focused on problem solving special education issues. All $(n=5,100 \%)$ of the male respondents indicated 


\section{Table 17}

Building a Better Education Administration Program All respondents without Administrative Endorsement

Administrative internships should include a unit that focuses on the administration of programs for students with disabilities.

$\begin{array}{llcc}\begin{array}{l}\text { Strongly } \\ \text { Agree }\end{array} & \text { Agree } & \text { Disagree } & \begin{array}{c}\text { Strongly } \\ \text { Disagree }\end{array} \\ 5 & 4 & 1 & 0 \\ (50.0 \%) & (40.0 \%) & (10.0 \%) & (0.0 \%)\end{array}$

All education administration programs should require at least one special education law course and one general 6 school law course.

$(60.0 \%) \quad(40.0 \%) \quad(0.0 \%) \quad(0.0 \%)$

Graduate level education administration programs should include role playing that focuses on problem solving special education issues.

Graduate level education administration programs should include 9 hours of special education course work.

$\begin{array}{cccc}4 & 4 & 2 & 0 \\ (40.0 \%) & (40.0 \%) & (20.0 \%) & (0.0 \%) \\ & & & \\ 2 & 1 & 2 & 5 \\ (20.0 \%) & (10.0 \%) & (20.0 \%) & (50.0 \%) \\ & & & \\ 1 & 2 & 4 & 3 \\ (10.0 \%) & (20.0 \%) & (40.0 \%) & (30.0 \%)\end{array}$

Course work devoted to leadership skills is not needed in graduate level education administration programs.

$\begin{array}{cccc}4 & 4 & 2 & 0 \\ (40.0 \%) & (40.0 \%) & (20.0 \%) & (0.0 \%) \\ 2 & 1 & 2 & 5 \\ (20.0 \%) & (10.0 \%) & (20.0 \%) & (50.0 \%) \\ & & & \\ 1 & 2 & 4 & 3 \\ (10.0 \%) & (20.0 \%) & (40.0 \%) & (30.0 \%)\end{array}$

West Virginia should require a specific administration endorsement for directors of special education.

$\begin{array}{cccc}2 & 8 & 0 & 0 \\ (20.0 \%) & (80.0 \%) & (0.0 \%) & (0.0 \%)\end{array}$

Note: Domain 3. Descriptors and subject responses for building a better education administration program for all respondents without administrative endorsement. 
they favored education administration programs including nine hours of special education course work. A majority $(n=3,60 \%)$ of the female respondents indicated they favored education administration programs including nine hours of special education course work. Once again, almost all $(n=4,80 \%)$ of the male and a majority $(n=3,60 \%)$ of the female respondents, when responding to a reverse order question, felt course work devoted to leadership skills was needed in graduate level education administration programs. Only one-fifth $(n=1,20 \%)$ of the male respondents indicated West Virginia should require a specific administration endorsement for directors of special education. Double the number $(n=2,40 \%)$ of the female respondents indicated West Virginia should require a specific administration endorsement for directors of special education (see Table 18).

\section{Qualitative Analysis}

Individual questionnaires with personal interviews and follow-up phone conversations were used to gather the data for analysis. The purpose of this process was to gain deeper insight related to individual director's perceptions of the skills they deemed necessary to be successful in their current positions. Six current directors of special education were selected using selective sampling based on three sets of paired opposite factors. The data gleaned from the respondents was analyzed with the constant comparative method. The culling of the data for meaning related to the responses of the directors was shaped by the researcher's focus presented in the study (Maycut and Morehouse, 1994).

The three sets of paired opposite factors were (a) the directors with the longest and shortest tenures in their positions, who are respectively referred to as LTD and STD, (b) the directors from the counties with the most and least number of complaints filed with the Office of 
Table 18

Perceptions of Knowledge and Training 98

\section{Building a Better Education Administration Program Male and Female Respondents without Administrative Endorsement}

Descriptor

Administrative internships should include a unit that focuses on the administration of programs for students with disabilities.

All education administration programs should require at least one special education law course and one general school law course.

Graduate level education administration programs should include role playing that focuses on problem solving special education issues.

Graduate level education administration programs should include 9 hours of special education course work.

Course work devoted to leadership skills is not needed in graduate level education administration programs.

West Virginia should require a specific administration endorsement for directors of special education.

\section{Females}

Administrative internships should include a unit that focuses on the administration of programs for students with disabilities.

All education administration programs should require at least one special education law course and one general school law course.

Graduate level education administration programs should include role playing that focuses on problem solving special education issues.

Graduate level education administration programs should include 9 hours of special education course work.

Course work devoted to leadership skills is not needed in graduate level education administration programs.

West Virginia should require a specific administration endorsement for directors of special education.

Subject Response

\begin{tabular}{|c|c|c|c|}
\hline $\begin{array}{l}\text { Strongly } \\
\text { Agree }\end{array}$ & Agree & Disagree & $\begin{array}{l}\text { Strongly } \\
\text { Disagree }\end{array}$ \\
\hline $\begin{array}{c}4 \\
(80.0 \%)\end{array}$ & $\begin{array}{c}1 \\
(20.0 \%)\end{array}$ & $\begin{array}{c}0 \\
(0.0 \%)\end{array}$ & $(0.0 \%)$ \\
\hline $\begin{array}{c}5 \\
(100 \%)\end{array}$ & $\begin{array}{c}0 \\
(0.0 \%)\end{array}$ & $\begin{array}{c}0 \\
(0.0 \%)\end{array}$ & $\begin{array}{c}0 \\
(0 \%)\end{array}$ \\
\hline $\begin{array}{c}1 \\
(20.0 \%)\end{array}$ & $\begin{array}{c}4 \\
(80.0 \%)\end{array}$ & $\begin{array}{c}0 \\
(0.0 \%)\end{array}$ & $\begin{array}{c}0 \\
(0.0 \%)\end{array}$ \\
\hline $\begin{array}{c}3 \\
(60.0 \%)\end{array}$ & $\begin{array}{c}2 \\
(40.0 \%)\end{array}$ & $\begin{array}{c}0 \\
(0.0 \%)\end{array}$ & $\begin{array}{c}0 \\
(0.0 \%)\end{array}$ \\
\hline $\begin{array}{c}1 \\
(20.0 \%)\end{array}$ & $\begin{array}{c}0 \\
(00.0 \%)\end{array}$ & $\begin{array}{c}2 \\
(40.0 \%)\end{array}$ & $\begin{array}{c}2 \\
(40.0 \%)\end{array}$ \\
\hline $\begin{array}{c}0 \\
(0.0 \%)\end{array}$ & $\begin{array}{c}1 \\
(20.0 \%)\end{array}$ & $\begin{array}{c}3 \\
(60.0 \%)\end{array}$ & $\begin{array}{c}1 \\
(20.0 \%)\end{array}$ \\
\hline $\begin{array}{c}1 \\
(20.0 \%)\end{array}$ & $\begin{array}{c}3 \\
(60.0 \%)\end{array}$ & $\begin{array}{c}1 \\
(20.0 \%)\end{array}$ & $\begin{array}{c}0 \\
(0.0 \%)\end{array}$ \\
\hline $\begin{array}{c}1 \\
(20.0 \%)\end{array}$ & $\begin{array}{c}4 \\
(80.0 \%)\end{array}$ & $\begin{array}{c}0 \\
(0.0 \%)\end{array}$ & $\begin{array}{c}0 \\
(0.0 \%)\end{array}$ \\
\hline $\begin{array}{c}1 \\
(20.0 \%)\end{array}$ & $\begin{array}{c}4 \\
(80.0 \%)\end{array}$ & $\begin{array}{c}0 \\
(0.0 \%)\end{array}$ & $\begin{array}{c}0 \\
(0.0 \%)\end{array}$ \\
\hline $\begin{array}{c}1 \\
(20.0 \%)\end{array}$ & $\begin{array}{c}2 \\
(40.0 \%)\end{array}$ & $\begin{array}{c}2 \\
(40.0 \%)\end{array}$ & $\begin{array}{c}0 \\
(0.0 \%)\end{array}$ \\
\hline $\begin{array}{c}1 \\
(20.0 \%)\end{array}$ & $\begin{array}{c}0 \\
(0.0 \%)\end{array}$ & $\begin{array}{c}1 \\
(20.0 \%)\end{array}$ & $\begin{array}{c}3 \\
(60.0 \%)\end{array}$ \\
\hline $\begin{array}{c}1 \\
(20.0 \%)\end{array}$ & $\begin{array}{c}1 \\
(20.0 \%)\end{array}$ & $\begin{array}{c}1 \\
(20.0 \%)\end{array}$ & $\begin{array}{c}2 \\
(40.0 \%)\end{array}$ \\
\hline
\end{tabular}

Note: Domain 3. Descriptors and subject response for building a better education administration program all male and female respondents without administrative endorsement. 
Special Education, who are respectively referred to as MCD and LCD, and (c) the directors from the counties with the most number of students and the least number of students identified as students with disabilities, who are respectively referred to as MSD and LSD. The monikers are used to ensure the promise of anonymity and confidentiality for the respondents.

\section{Interviewee Background}

LTD is a male with 30 years experience in the position. In those 30 years, this individual taught Pre-K, was a teaching principal, a special education classroom teacher, and a special education coordinator en-route to becoming the director. At the time he obtained his current position, an administration endorsement was not required, although he does hold one. LTD indicated the endorsement through West Virginia University with transfer hours from Marshall University was completed in 1972. Other duties associated with LTD’s current position include all federal programs, Title 9, Section 504, and staff development.

STD is a female only 10 months into her current position. The posting for her position required the successful applicant to have an administrative endorsement, special education certification in one or more areas, and experience in teaching special education. Her career began as a regular educator. She moved to special education as a teacher providing Gifted services and then to a district level coordinator for Gifted services. Immediately before becoming the director she was an elementary principal. STD’s administrative endorsement covers multiple areas, but nothing related specifically to special education. She holds an M. A. in both special and regular education. Her endorsement was completed in 2000 through Marshall University

MCD is a female with two years experience as the special education director. She 
received a masters’ degree from West Virginia University in 1993 and an administrative endorsement from Salem University in 2002. Her career started as a regular education teacher and then she became the administrator of the GEAR UP program before her assuming her current position. MCD’s position required a masters' degree and an administrative endorsement.

FCD is a female starting her fifth year as a director. She started as a speech-pathologist and moved to senior pathologist to a special education coordinator and then to director. In 1996 she obtained her administrative endorsement through West Virginia Graduate College. No specification was given, but an administrative endorsement was required for the position along with an endorsement in one exceptionality and three years experience in special education.

MSD is a female with two years experience in her current position. Her administrative endorsement from Marshall University was obtained in 1998. Prior to becoming the director, MSD was a special education teacher for 13 years, a special education specialist for five years, an assistant principal for 4 months, a principal for six months, and a director of Alternative Education for two years. Due to a combining of two positions, her current position was not posted, yet it does require an administrative endorsement, special education certification, and special education teaching experience.

LSD is also a female. She has served 13 months as her county’s full time special education director. Prior to that she served nine months on a part time basis. Her first 15 years of teaching were in special education. Immediately before her directorship, she taught one year in a regular education classroom. The posting for her position required a general education endorsement and an undergraduate endorsement in special education. LSD completed her administrative program through Marshall University Graduate College in 2002. 


\section{Responses}

While the interviews were designed around the same three domains as those specified in the surveys, the questions were focused more on gathering data directly related to the knowledge base directors perceived they needed in order to be successful in their positions. The first domain provided demographic information as well as information related to the formal preparation of the respondents.

The respondents varied in regards to their general preparation programs requiring special education coursework. Four of the six respondents indicated their programs did not contain any special education coursework. The respondent (LSD) from the county with the least number of identified students indicated:

I did go through a general education administration program that offered no special education courses. My only exposure to anything dealing with special education was embedded in another class. The extent of this was the state special education director coming into the class, distributing and discussing Policy 2419. It was very basic and I already knew all that she presented. I guess for a student in the program without any special education background, it may have been informative.

Of the two individuals reporting their programs did require specific special education coursework, the responses carried a common thread related to a law class requirement. The respondent (FCD) from the county with the fewest number of complaints filed with the State Office of Special Education provided the following twist related to program management: Special Education Law was the only one (required) and I was given an automatic “A” in the course because of my work experience in special education. I had a personnel class, a 
finance class, a general education law course, and a couple of curriculum classes, but I can't say that any of that information was particularly helpful with the actual day to day management of a special education program. It did, however, help to familiarize me with general areas in which I needed to be conversant.

Related to leadership skills that may have been presented in the respondents' preparation programs, communication and interpersonal skills were mentioned by almost all of the directors as being present in some form. Although those skills were most often indicated, one director (MSD) from the county with the greatest number of identified students with disabilities noted, "They (general administration courses) may have assisted in developing interpersonal relationship skills, but the experiences I encountered on the job were the way I developed my leadership skills (be they good or bad).

Role-playing that focused on problem solving special education issues presented varied responses. The director (STD) with the shortest tenure to the position, only 10 months on the job with a general administrative certification and a masters in special education, indicated:

A graduate class that was very helpful to me, hand "in box" type activities. Various scenarios were given through an activity; in each scenario, we were given a role to play, such as principal and then had to solve the problem. While these activities were very time consuming, years later I appreciate the learning that I gained from those activities. When questioned about their perceptions about how well prepared their programs made them, only one director (STD) indicated she felt prepared. That individual's response illuminates other related issues:

I was very well prepared due to a combination of my M. A. in Special Education, my 
principal experience and also what helped me was that I was working on my M. A. in Educational Leadership at the time I was a principal. It was very valuable to have situations come up at school and then have a group of peers at night class to discuss and help problem solve those issues. I am afraid that the emphasis of on line learning will significantly decrease those opportunities for networking.

The same individual, when probed about what other knowledge base was needed, offered, “State procedural guidelines and practices should have been emphasized more. More information on the process of preparing a good Needs Assessment. More information on collecting data per state resources.”

Respondent FCD offered a counter and more prevalent view among the directors: My administrative program really didn’t provide me with much that has been of value in my current position. Most everything that I've needed in order to be successful as a special education administrator was learned either from my predecessor or through my own experiences on the job.

When probed about what other knowledge base and leadership skills were needed and not offered, the same director revealed:

If there were an administrative program specific to special education, it should include coursework in both federal and state special education law and regulations (including perhaps an entire course in discipline), finance (including how to do budget supplements, budget transfers, how to allocate funds to salaries, fixed charges, and all the other line items involved), curricular programs and materials specifically available to special education teachers, and data analysis/interpretation. Leadership skills that come to mind 
include conflict resolution, communication skills, how to deal with continual change, how to allocate limited time and resources. I'm sure there are others, but I just don't know what they might be right now.

The second domain was concerned the directors' perceptions of the knowledge and skills they learned on the job. While most of the directors indicated their formal preparation was lacking, two indicated they felt a sense of readiness when they entered the job. Based on a combination experience and education, STD offered:

I felt ready, I feel like I have already weathered many storms. Nothing like a principalship to prepare you. After you have survived being a principal, no position looks scary anymore. Yes, I feel my knowledge base was sufficient. I think I have the perfect combination of experiences and education. Teacher and principal experience, M.A. in special education and M.A. in Educational Leadership. Principals love that I have walked in their shoes. I am an advocate for the principal when the central office staff forgets what (it) is really like on the home front.

From a perspective of excitement and tutorship from the previous director, the director (FCD) with the fewest complaints filed with the Office of Special Education offered: I was so excited when I first started this job that I thought I could do anything! I truly thought I was ready and that I knew everything I needed to know. I thought so then (that I had a sufficient knowledge base). Things got off to a very positive start. A counter view of interest was present by the director (LTD) with the longest tenure in the position. The response offers insight related to the time frame the director completed a certification program: 
At the time my knowledge base was not sufficient. In 1978 there was a huge learning curve for our county, the state and nation in the provision of special education services. I believe that this situation had a positive impact on the position.

When asked their perceptions about what knowledge base and leadership skills were lacking when they entered their current position, finance/budgeting issues were the number one concern. The lack of any knowledge about allocation of funds, managing accounts, and how to read a financial report was compounded by the time lost factor. FCD reported:

The only thing I really didn’t know much about was finance and that lack of knowledge or experience proved to be problematic for me until our new Finance Director was hired. He was able to show me just how to do everything I needed to do in order to efficiently manage finances. I spent lots of time trying to figure out how to manage all my accounts until then so it took time away from other aspects of the job.

The same time lost concern was expressed by LSD:

Finance has been my number one challenge. This may be attributed to the brand new finance officer that started in our office when I did. The impact has been that I have had to spend many hours learning the requirements and actually how to read a financial report. I have spent several weekend hours pouring over reports and making necessary revisions. Again, that is what happens in a small county. Other areas of knowledge the directors indicated were lacking including personnel laws, IDEA regulations, No Child Left Behind legislation, law related specifically to special education, how to conduct a “Needs Assessment,” teaming, time management, building interpersonal relationships with teachers and principals. One administrator, MSD, made these points related to 
the last two items:

I was not a good leader in developing time management. I still work 12 plus hours a day. Another area of concern was my relationship with school administrators. We had a good relationship but I felt their equal and they all looked to me as someone in a higher position. In terms of leadership experience I am still new at this position and there are administrators with 25 plus years asking my permission for something. The interpersonal and communication skills needed to effectively manage and run the district were a concern to MCD as she took over her county’s program: No one in the office offered input on how to do the paperwork .... how to follow the proper procedures of the school system. I got very frustrated at first. I felt I understood my continuing the job, but didn't understand the functioning of the board office. I did not know how to deal with this difficult office in order to be accepted. I really questioned myself why I took the job.

Reaching a consensus and the lost time factor were issues related to daily management tasks for FCD:

I had no clue how to get folks to reach consensus and I'm not sure I know how even now! Having IEP team members at odds at time has taken up way too much time and on a couple of occasions has resulted in complaints. This obviously takes away time needed to deal with daily management tasks.

All those interviewed stated their number one way of expanding their knowledge base and leadership skills was the networking and contacts they had developed with their peers. 
Statements such as "I never hesitate to ask for help from my peers when I realize I need it," “continually network with my peers,” and "I have been extremely lucky with having peers to guide me through the many questions/concerns I have had. I sometimes wonder what I would have done without their support” were echoed by all respondents.

The directors offered consistent answers related to how long it took for them to feel they were effective providing leadership for their programs. The concern was focused around changing regulations and feeling like the program was theirs. The longest tenured director, LTD, indicated "Two years, or until the state and fed's changed the regulations." FCD, the director with least number of complaints filed with the Office of Special Education noted time was not a factor, but ownership of the program was her concern, "I never felt that I was ineffective, although it did take me a while to establish that this was my program, not my predecessor's!” The director (LSD) from the county with the least number of students identified in need of special education service noted:

As I mentioned, I have had a difficult task to undertake. Our school system had had a director in name only for a few years. As you can imagine, things had slipped considerably. I firmly believe in "What gets monitored gets done.” Without monitoring and guidance, teachers had moved into doing only what was necessary in the shortest amount of time. I found myself with the task of bringing the system into compliance. Now that IDEA has been reauthorized, I find myself trying to lead the teachers through the changes while still trying to bring us into compliance. I am still not sure I am providing effective leadership. I guess I will not feel effective until I go through my first monitoring and get the results. Thankfully, I have not had to deal with litigation. I credit 
this to being a hometown girl who worked in the system for several years and know most of the parents with which I am dealing. Up to this point, I believe the parents feel I want what is best for the child.

The final domain was centered on building a better preparation program. The focus was whether or not West Virginia should require a specific endorsement for special education directors and what knowledge base and leadership skills should be addressed. Overwhelmingly there was agreement, five of the six directors, that a specific endorsement was not needed. The consensus was that a general education administration endorsement was sufficient since most felt that individuals who aspired to the position would have prior experience in the special education field. Besides emphatic “No” responses, two directors succinctly stated their views. STD noted, "No. People without such a credential might have a varied background that would enable them to be successful.” LSD presented a complimentary idea, “I don’t think it should require additional hours. I think making special education a certification by itself would be too restrictive.”

The lone director, LTD, in favor of a specific endorsement felt certain components should be covered. He offered insight related to curriculum and instruction, personnel laws, special education regulations, transportation regulations, school board relations, community relations, grant writing, parent involvement and No Child Left Behind requirements as curriculum areas that needed to be incorporated into an administration preparation program.

There was overall consensus for the components an endorsement should include. Aside from what LTD offered and what already has been presented, the directors mentioned ethical and legal issues, discipline, needs assessments, pre-school and universal pre K programming, and 
finance. Upon a review of the literature review for this study, it is evident these findings are also supported in earlier studies. 
Perceptions of Knowledge and Training 110

\section{CHAPTER 5}

Discussion, Conclusions, and Implications

In the early stages of planning this research and as brought to light in Chapter 1, personal experiences shaped the question. As the study unfolded and data started accumulating, the excitement of reviewing the responses led to making predictions based only on those early replies. What picture or pictures would come to light when all the data was finally analyzed? What themes would emerge to provide direction as to how to put it all together? Would the findings be of consequence to those in the position to influence policy regarding certification issues related to the administration of special education programs? Would practitioners find relevant meaning in the data and subsequent interpretations? Would the findings and results be of value in the future to those who hold a similar interest and want to use this study as a template?

The purpose of this study was to gain an understanding of the knowledge base administrators of special education programs perceived necessary for them to be successful in their current positions. The study involved the collection of data through a mixed method design using qualitative and quantitative analysis of the data. Individual surveys were distributed to special education directors in West Virginia. Six directors were selected using selective sampling for more in-depth study related to the research question. Data analysis began with the collection of the first survey, continued through the questionnaires, personal interviews, and follow-up phone interviews to verify the transcription of the data. The research resulted in the researcher being able to identify certain commonalities and themes in the perceptions of the participants in the study. Once a culling process was completed with all the data, relationships between those were presented. 
This chapter summarizes the findings and discusses interpretations of them. Upon submitting that information, it describes conclusions drawn from the study and possible future implications of the study for practitioners, governmental agencies that oversee special education programs, institutions of higher education, and for future researchers. Finally, the chapter concludes with some personal reflections on this odyssey.

\section{Discussion}

What follows serves to put it all together in providing a picture for the reader. The data from the survey is looked at regarding the most relevant and salient themes to the research question that were generated by male and female responses, those with an endorsement compared to those without an endorsement, and the perceptions of the newer generation compared to the longer tenured directors. That discussion is presented concurrently with the themes gathered from the interviews. It is a combination of the aerial view of the survey and the ground truthing of the interviews that this researcher believes will provide insight for addressing the research question. This alludes to Krathwohl's (1998) view of quantitative numbers being expressed in words in qualitative reports, how both methods may offer a similar view, and that they actually may reinforce one another.

Overall 27 females and 18 males returned usable surveys while six practitioners completed the questionnaire and interviews. At the heart of their responses was the question of the knowledge base directors need. That question was presented in each domain along with probes designed to specifically ask what knowledge was present in the participants’ preparation program, what was needed for their position, what was learned on the job, and what would be offered if they, the directors, could build a program. 
A close inspection of the survey instrument reveals specific questions in each domain which address the central issue. Domain 1 was designed specifically for only those who held an endorsement. The intention was to uncover if certain courses, one related to special education law and one related to conducting an IEP meeting, were offered to the participants during their graduate preparation. Additionally, the overall perception of their administration program preparing them for the current position was posed. While the respondents of the interviews indicated those areas were part of the needed knowledge and skill base, the data from the survey revealed those areas were not addressed in the respondents' programs. A point of interest was four respondents indicating their endorsement was from a program specifically for special education administration, yet only one indicated having a special education law class while two indicated course work related to chairing an IEP meeting. Related to their overall sense of preparedness from the endorsement programs, the survey data and interview data did reveal similar findings. Slightly over fifty-four percent (54.3\%) of the survey respondents indicated their programs did not adequately prepare them, while $66.6 \%$ of the interviewees indicated a similar response.

Domain II was designed so the responses of all the participants were considered. The intention of this domain was to explore the concept of on-the-job training and what knowledge base was acquired from those experiences. Specific questions related to fostering parent involvement, cultural diversity, finance and budgeting, and state and federal policy were presented to the directors. The respondents indicated their knowledge of those areas was acquired from their work experiences related to the responsibilities of the position. The same topics were identified by the interviewees as major areas of knowledge that were mainly learned 
while on the job, with the number one area being finance.

When asked to describe their sense of readiness when entering their current position the majority, 4 of 6 , indicated they were not prepared. The two interviewees who did indicate they were adequately prepared, did not have a special administrative endorsement for special education, offered different reasons. One, STD, felt her course work and other job related experiences had prepared her. The other, FCD, indicated her course work did little in terms of preparing her for her job: she had learned from her predecessor. When the survey participants responded to a similar question, if their on-the-job experiences were more helpful than their course work, $88.9 \%$ of all respondents and $88.6 \%$ of those with an administrative endorsement, indicated on-the-job experiences.

Domain III, also for all participants, was conceived with the intent to allow directors the opportunity to provide insight about the knowledge areas that they felt would be essential if they were allowed to design a preparation program. Their responses to domains I and II would act as a catalyst for thinking outside the box. Not only were specific questions presented related to law, but the participants were afforded the opportunity to present their perceptions related to internships, law, the number of special education hours that should be offered, and problem solving. There was strong agreement from both groups of study participants that these areas should be included in a general administration preparation program. When each group was presented with the question of whether West Virginia should require a specific administration endorsement for special education directors, again there was solid agreement that the state should not require such an endorsement. Close to $60 \%$ of the survey respondents (57.8\%) were not in favor of a state requiring one while the interviewees indicated 5 to 1 that the state should not 
require a specific endorsement. The lone advocate for the endorsement was a male. Drilling down deeper into the survey data revealed that the majority of the respondents did not want the state to require a specific endorsement; however, the majority of the females already holding an administrative endorsement indicated the state should require the more specific one.

\section{Conclusions}

The research question was concerned with the perceptions current special education directors have related to the knowledge base they need in order to be successful in their current positions. From the interviews the question was specifically answered revealing a needed knowledge base in (a) finance and budgeting, (b) special education law, (c) personnel laws, professional and service, (d) Policy 2419 regulations and procedural compliance issues, (e) conducting a needs assessment, (f) public relations, (g) IDEA regulations, (h) No Child Left Behind regulations, (i) legal and ethical practices, (j) curriculum and instruction, educational programming, (k) discipline, (l) how to complete the LEA application, (m) transportation issues, (n) program evaluation and monitoring, (o) school board relations, (p) preparing for an onsite monitoring, (q) preschool special needs, and (r) universal pre K programs.

While respondents to the interviews indicated those areas were part of the needed knowledge and skill base, they also indicated not all of those areas were offered as courses in their preparation. Going deeper into the follow-up interviews, light was shed on special education topics being embedded in their general administration programs. One of the interviewees (STD) indicated:

I had one special law class, but other courses pertinent to special education were in my program. I had a general law class, one on school finance, and a communication class 
I thought was very helpful in dealing with and working with teachers and parents. Another interviewee (FCD) indicated having only to take Special Education Law. She also noted in subsequent conversations that:

Other areas were covered in my general administration program. Aside from a personnel class, a finance class, a general education law course, and a couple of curriculum classes, I did have projects that addressed communication and interpersonal skills that I found invaluable working with parents in general and especially at IEP meetings.

Interviewee LSD also reported a lack of special education course work in her program but stated they were "embedded” in other course work. She noted, "The program did have a heavy concentration on communication and interpersonal skills. Many classes focused on dealing with teachers, service personnel, parents and the press.”

The data from the survey revealed a different outcome. Eighty percent of the respondents indicated course work dedicated to special education law was not in their endorsement program. The data was even stronger related to having training for chairing an IEP meeting as 85.7\% indicated their program did not prepare them for such a task. As for special education law being addressed in the administration programs, the gender-specific data of the survey again revealed a difference when compared to the interviewees. The males (77\%) and females (81.8\%) were very close in indicating overwhelmingly special education law was not part of their administrative endorsement program. In a comparison of the data for course work preparing them to chair an IEP, the male (84.6\%) and female (84.4\%) respondents were again similar in indicating that area was not addressed in any course work. Surprisingly, of the four respondents indicating their endorsement was from a program specifically for special education administration, only one 
indicated having a special education law class while two indicated course work related to chairing an IEP meeting.

This researcher was able to identify from the data provided by groups of subjects in the study what they determined was needed and what would benefit special education directors. While some of that base was offered, either directly or indirectly, in administration preparation programs, it was the on the-job-experiences that allowed the practitioner the opportunity to expand, refine, and apply that knowledge. If we take those findings and apply them in a broader manner to building a better administration preparation program, perhaps the issue is not a specific special education program requirement, but rather the design of a program. Interviewee FCD offered:

How about an educational administration certificate with an emphasis on either general or special education? Much of the basic coursework could be the same since much of the knowledge base and leadership skills would not differ for general education and special education administrators. There would be courses offered in specific areas that differ e.g. law, discipline, curriculum, etc.

FCD does offer a salient point, one to be considered as an implication in the next section. Here again it is pertinent to refer to the literature review. Crockett's (2002) Star Model offers support for FCD’s perception.

\section{Implications}

It is important here to point out the varied views uncovered from both sets of participants in the study while keeping in mind the range of experience each brought to the table. That range mirrors the words of Sage (1981) related to the continuing evolution of the practice of special 
education administration. The experience, or lack of, is seen in perceptions related to preparedness for the position and what would be changed as shown through the review to provide potential remedies. The evolution is seen as a shift of ownership or territorialism related to programs from a yours and mine mindset to a more collaborative approach supported by Goor (1995), Burrello (2001) and others. The longest tenured director saw the evolution as an opportunity for growth and for special education to be a leader in a collaborative process much as Crockett (2002) conceptualized in the Star Model.

Endorsement or licensure issues are a critical area for all respondents and can be seen in the literature review. Boscardin and Lashley (2003) noted a lack of acceptance of national standards for certification at the stem of the concern. The findings revealed the respondents were not in favor of a specific endorsement. The tie of the issue between the preparation programs and the licensure agencies is echoed not only in the findings but supported in the literature review. The problem is further magnified as the role of the administrator of special needs programs broadens, again as evidenced in the findings and of a review of the literature.

There is a conduit for the points brought forth in the literature review and that are further illuminated in the findings that have been presented in this chapter. Our attention now turns to a discussion of the major complementary points of both sections of the study.

Aside from addressing the question central to the research, the data provided this researcher with several other points related to implications or recommendations for several parties. This discussion will be presented in somewhat of a free association method. Questions are asked, not necessarily to be answered now, but perhaps to incite interest in others who, in time, will want to research the issues derived from this study. While level three headings 
separate the major areas presented, it is in no way intended that these areas are not related to each other. The reader will see several ties between the topics.

The implications or recommendations address not only the immediate concern, but serve to offer a potential start on related issues that will need to be addressed in the future. These starting points are not limited to practitioners, current or prospective ones, but reach out to governmental agencies overseeing special education programs, institutions of higher education offering preparation programs, and future researchers in this area.

Gender Issues.

The first point from the survey data is that female directors greatly outnumber the male directors. The same held true by random selective sampling of the interviewees: five of the six were female. All of the females had been in their current position for five years or less, while the one male interviewee had 30 years in his current position. The survey data supports the interview data. Of all male respondents more than half (55.6\%) are considered new to the position, while $85.2 \%$ of the females had 10 years or less experience. More females (31.9\%) are of the new millennium in receiving their administrative endorsement as compared to males (15.3\%). Why are we seeing this trend now? Perhaps of interest would be to see who held those positions when special education was in its infancy? Are females better prepared? Do they have higher expectations?

Are females better prepared? This becomes a difficult question to answer when the data reveals all the respondents to the survey held at least a Master's degree. There were an equal number of Master's held by the respondents without an endorsement. But if one considers having taught in special education prior to being a special education administrator as part of 
better preparation, close to $90 \%$ of the females had taught in such classrooms as compared to only $50 \%$ of their male counterparts. This point becomes more interesting when you consider that all of the females without an administrative endorsement had special education classroom experience prior to becoming a director while only $60 \%$ of males had the same experience. While several of the six interviewees indicated having taught in a special education classroom, not all volunteered that information. Perhaps the study could have been strengthened if that same data were available from all of the interview participants. Another issue to ponder from this section is related to those participants who hold a Master's degree yet do not have an administrative endorsement. Is the Master's in an area specific to special education?

\section{Higher Education Institutions.}

Where the respondents reside is another implication issue that would be of interest to higher education institutions. In looking at the colleges and universities attended by the respondents, a possible related issue for higher education would be to extract the regional preferences, if any, for the delivery of administrative endorsement programs. A more in-depth review of the data could provide information related to the course work offered by those institutions. Insight could be gained beyond the need for coursework related to the technical aspects of compliance. Aside from knowledge related to regulations and monitoring, practitioners are telling them a broader approach is needed. That approach focuses not only on knowledge such as finance, law, and individual exceptionalities, but best practices for instructional strategies, effective schools, staff development, personnel matters, and on interpersonal leadership skills.

Communication and interpersonal skills, not only for the sake of explaining compliance 
policy, but also for effectively expanding knowledge to students, parents, teachers, fellow administrators and to superiors has become essential. A skill base for communicating to and with all involved in the total educational process needs to be considered in endorsement programs. Internships could be useful in providing an opportunity to hone those skills. The survey data directly supported the need for internships. When asked if internships should be part of an administrative endorsement program, 94.6\% of all survey respondents agreed. Of interest is that only one of the interviewees mentioned internships as part of an administration program. This information could assist efforts to see which programs are actually offering the course work identified in this study and how it was offered. On-line course work could influence or negate regional preferences.

Another related issue for both higher education and future researchers would be to consider how the respondents acquired their knowledge base. We can draw on the information presented in the Discussion and Conclusion sections of this chapter to provide part of the answer. The components are there in both instruments even though they are more directly addressed in the interview.

I offer here that we look again at what LTD offered related to change. This interviewee received his administrative endorsement in 1978. He offered this insightful perspective to times changing and the need for administrative preparation programs to keep up with the change. He stated:

At the time my knowledge base was not sufficient. In 1978 there was a huge learning curve for our county, the state, and the nation in the provision of special education services. I believe that this situation had a positive impact on the position. 
With the recent reauthorization of IDEA and the demands of No Child Left Behind perhaps we are again in a situation where addressing the issues raised in this research could have another positive impact on the position.

Addressing these implications would serve a twofold purpose: not only would higher education institutions be better able to market their programs, but individuals interested in specific course work and programs would have a data base from which to compare programs. Once again, the literature review complements these issues and lends support to the tie for future research implications.

\section{Licensure.}

Governmental agencies that oversee special education programs may want to access the findings of this research. Consideration might be given to how policies can shape practice, or perhaps more strongly stated, how the absence of policies can also shape practice. It is evident from the literature review that this issue is prevalent across the nation. The absence of policy that sets unified and universal standards for licensure is a prime example of state and local educational agencies’ practices of posting and hiring special education administrators. A review of the findings related to both the quantitative and qualitative aspects of the study further supports this implication. Neither group of participants favored a specific administrative endorsement for special education. When over half (54.3\%) of the survey respondents and 5 of 6 one of the interviewees do not favor a specific endorsement, could that not imply that the absence of policy is shaping practice?

Consider that of the 45 respondents, 10 did not have an administrative endorsement in either general education or special education. Why not? This seems like a relatively high 
number for a job that one would consider “administrative.” To compound this point, and maybe the one raised previously, is the preparedness factor. A majority of the respondents without an endorsement indicated they had taught in a special education classroom. Still, one in five, 20\%, had not. And, they did not have any kind of administrative endorsement, and, yet they were qualified to be special education administrators. It tends to make one wonder how they got the job.

The issues of being prepared and requiring a special endorsement for special education directors recurred over and over. Consider this: less than one half (45.7\%) of all respondents indicated West Virginia should require a specific administration endorsement for directors of special education. Yet conversely, 54.3\% indicated they were not adequately prepared for their current positions. The interview data supports this, 4 of the 6 indicated they were not prepared. Of the 10 survey respondents who did not hold any type of administrative endorsement, the issue is of more concern. Seventy percent did not favor the state requiring a specific endorsement. Overall it is safe to infer, they didn't feel prepared for the job, yet they didn’t want a separate endorsement requirement. Why not? This seems contradictory. Perhaps a future study could incorporate finding out how prepared the respondents without any endorsement felt when they obtained their current position.

Drilling down that data further, males (69.2\%), by more the two times the females (31.8\%), indicated they were adequately prepared. Those findings are interesting when considered in conjunction with the specific endorsement issue. Less than one-fourth (22.3\%) of the males favored the endorsement while more than twice the number (54.6\%) of females favored the endorsement. This implies a great expectations issue. While their reasons differed, 
it is interesting to note that 2 of the 6 interviewees, both females, indicated they were prepared. Even though differing in certain aspects related to preparation, both alluded to their prior experiences more so than to their educational preparation. Here again we see related issues, gender, licensure and higher education (perhaps to require an internship to support in-field experiences), and another question for future researchers to ponder.

In consideration of the litigious nature surrounding special education and the demands of No Child Left Behind, would it not better serve governmental licensing agencies to know what counties have or, perhaps more appropriately, do not have adequately trained administrators providing leadership to such high profile programs? If that is the case, would it not serve both licensure agencies and higher education to jointly address the issue?

\section{Practitioners.}

Given that current and prospective special education administrators will be grounded in No Child Left Behind legislation and its related inevitable cycle of change, a stagnant approach to their positions will not suffice if their programs are to meet legislated outcomes. Meeting those legislated outcomes should not be the final chapter. If settling only for competency is the final goal, we will short change the students under our watch. Aside from investigating preparation programs in efforts to find one(s) that offer flexibility to meet the ongoing change, directors need to continue to expand their own personal networking. The networking should not be limited to peers. The vision needs to be broader: seminars, workshops, on-line professional resources, state and national conferences presenting research-based information and strategies, professional literature and organizations are but a few of the available resources directors can access to obtain desired knowledge. 
While recognizing that the principal is the chief instructional leader in a school, the director is accountable for more than making sure the necessary supplies and material are available to assist the principal in these responsibilities. A system offering pertinent, up-to-date research-based staff development that reaches beyond the compliance and technical aspects of special education must be studied and implemented. As indicated in the findings of the interviews, directors should keep in mind that preparation programs, networking, and professional development should expand the opportunities for learning in the areas of individual exceptionalities and their associated characteristics. Such opportunities also focus on the impacts of those disabilities on individual learning differences, research-based instructional approaches that reflect best practices for students with disabilities, and creative ways to increase positive parental participation in the total educational process.

The relationship of the director to the principal is another crucial implication supported in the literature embedded in the findings of the study. If the knowledge base is now presented indirectly in general administration programs, why not present the information directly in those programs? When presented with the question of whether general administration programs should include 9 hours of special education course work, three-fourths ( $n=34,75.6 \%)$ of all respondents indicated it should. If practitioners are saying this is what they perceive they need, wouldn’t this be of interest to both higher education and state licensure agencies?

\section{Future Research.}

This study provides a menu of the needed knowledge base practitioners have identified as necessary for success in administrating special education programs. As mentioned, all the implications appear to be interrelated. It is extremely difficult to present any of the implications 
as isolated entities. Future researchers are encouraged to consider the aforementioned related implications of that identified knowledge base and to replicate this study in order to test the applicability and generalizability of the findings. Similar studies could be conducted in broader geographic regions, in more populous states, in metropolitan and rural areas to identify the needs of directors in those areas and to compare and contrast the perceptions offered by respondents. Future studies could lend themselves to a thorough understanding of the knowledge related to the differing perceptions and the factors that influence those perceptions. Such research could in turn not only provide insight, but also could contribute to effective ways of obtaining the identified knowledge base.

Additionally, care should be given in a purposeful review of the design of the instruments. While not a marriage, the instruments do present, to a degree, a semblance of agreement and of being mutually supportive of each other. But future researchers have to ask themselves, do they directly address the research question? Addressing the qualitative interviews, it is apparent that they do. Addressing the quantitative surveys, perhaps the design of the second and third domains could have been stronger. Future researchers need to review the literature advanced since this study and then build domains based on that review to strengthen the format.

While several implications have been addressed here, this researcher is well aware that the surface has been merely scratched. Future researchers have been offered thought; now their own divergent thinking skills must take over to pursue future research in this area.

\section{Personal Reflections on the Research Process}

Now that the odyssey has come to an end, there is time for purposeful reflection on the 
process(es) involved in this study. From this reflection, certain aspects of the study can be identified that future researchers may want to consider when conducting a similar study.

First, they should follow the same process of introducing the quantitative instrument, the survey, to prospective participants. Having a forum at a state-wide meeting provides immediate access to a majority of that population and can be advantageous in obtaining a meaningful and workable number of returns. A caution here is in order: not only an overview of the study should be presented, but also forethought should be given to succinctly explain each domain and any reverse order questions it may contain.

Second, the researcher should avoid any breaks or time off from the process. Allowing down time, for any reason, only serves to put time between the steps and could lead to the break down of the sequential thought process. It becomes difficult to rely on one's own recall after long breaks from the study to be able to start up again without duplication of some of the previously completed tasks.

Next, while the logic-inductive and numerical approaches in mixed method studies can blend, the researcher has to remember that the approach can limit the study. The issues of anonymity and confidentiality could be at odds with a review of documents that are not a matter of public record. This researcher has gained the following perspectives related to each approach and offers future researchers an opportunity to learn from these insights. Certainly survey questions can guide the respondents, almost channeling them to provide a response to a series of questions that tends to dictate a prescribed answer and offers only an altitude view of the issue.

Interviews tend to be more open-ended, offering a more ground level view of the concern, and allowing the interviewee to provide tangents or emergent themes. Both are not 
without limitations. Future researchers will come to their own conclusions when presented with a possible mixed method design; consider those perspectives here as a guide, not as a deterrent.

Finally, future study should include institutions of higher education. They were referred to and talked about, but not interviewed or surveyed related to their perceptions of the research question. Aside from the opportunity to present their perspectives on the question and perhaps to defend themselves, their insight could be the missing link in future efforts to strengthen similar studies. 


\section{References}

Alexander, K., \& Alexander, M. D. (1992). American public school law. St. Paul, MN: West.

Alexander, K., \& Alexander, M. D. (1984). The law of schools, students, and teachers. St. Paul, MN: West.

Arick, J. R., \& Krug, D. A. (1993). Special education administrators in the united states: Perceptions on policy and personnel issues. Journal of Special Education, 27(3), 348364.

Artiles, A., \& Trent, S. (1997). Forging a research program on multicultural preservice teacher education: A propose analytic scheme. In J. Lloyd, E.J. Kameenui, \& D. Chard (Eds.), Issues in educating students with disabilities: Supervision in special education (pp. 275305). Mahwah, NJ: Lawrence Erlbaum Associates, Inc..

Aspen, M. (1992, April). Principals' attitudes toward special education: Results and implications of a comprehensive study. Paper presented at the $70^{\text {th }}$ Annual Convention of the Council for Exceptional Children, Baltimore, MD.

Bateman, D., Boscardin, M.L., Crockett, J.B., Di Paola, M., Lashley, C., McLeskey, J., \& Thornton, H. (2003, February). Research Planning Session: Administration in Special Education.

Bays, D. A. (2001). Supervision of special education instruction in rural public school districts: A grounded theory. Unpublished doctoral dissertation, Virginia Polytechnic Institute and State University, Blacksburg.

Belenky, M. F. (1992, October) Bringing balance to the classroom or workplace, paper 
presented at the Wisconsin Women’s Studies Conference, Pre-conference Workshop, Green Bay, WI.

Boscardin, M. L. (2004). Transforming administration to support science in the schoolhouse for students with disabilities. Journal of Learning Disabilities, 37(3), 262-269.

Boscardin, M. L., \& Lashley, C. (2003). Special education administration at a crossroads: Availability, licensure, and preparation of special education administrators. (COPSSE Document No. lB-8E). FL: University of Florida, Center on Personnel Studies in Special Education.

Burello, L. C., Lashley, C., \& Beatty, E. (2001). Educating all students together: How school leaders create unified schools. Thousand Oaks, CA: Corwin.

Burello, L. C., \& Zadnik, D. J. (1986). Critical success factors of special education administration. The Journal of Special Education, 20(23), 20-26.

Cambron-McCabe, N. (1997). Confronting fundamental transformation of leadership preparation. In J. Murphy \& P.B. Forsyth (Eds.), Education administration: A decade of reform (pp. 217-228). Thousand Oaks, CA: Corwin.

Carta, J., \& Greenwood, C. (1997). Barriers to the implementation of effective educational practices for young children with disabilities. In J. Lloyd, E.J. Kameenui, \& D. Chard (Eds.), Issues in educating students with disabilities: Supervision in special education (pp. 261-274). Mahwah, NJ: Lawrence Erlbaum Associates, Inc..

Council of Administrators of Special Education. (1993). CASE future agenda for special education: Creating a unified education system. Albuquerque, NM: Author Center on Personnel Studies in Special Education. (2004, February). Workforce watch: An 
insufficient supply and a growing demand for qualified special education personnel. What school districts should know (Policy Brief No. 17). University of Florida. Gainesville, Fl. Warger, Evay \& Associates.

Cessna. K.K. (1995). Working with government: Leading while responding within the larger system. In M. Goor (Ed.), Leadership for special education administration: A casebased approach (pp. 61-82). Fort Worth, TX: Harcourt Brace.

Claerbout, J. (1991). A scrutiny of the introduction. Geophysics: The Leading Edge, 10, 39-40.

Connor, L. (1961). Administration of special education programs. New York: Teachers College Press.

Connor, L. (1966). Preparation programs for special education administrators. Exceptional Children. 33, 161-166.

Council for Exceptional Children (CEC). (1993). Policies for the delivery of services: Responsibilities of the school administration. Retrieved November 12, 2004, from http://www.cec.sped.org/pp/polresp.html.

Council for Exceptional Children (CEC). (2003). What every special educator must know: Ethics, standards, and guidelines for special educators. Reston, VA: Author.

Crockett, J. (2002). Special education's role in preparing responsible leaders for inclusive schools. Remedial \& Special Education, 23, 157.

Crockett, J. B., Sughrue, J. A., \& Berlin, L. F. (2003, November). Leadership preparation and special education: Learning from the field. Paper presented at the national convention of the University Council for Educational Administration, Portland, OR.

Dayton, J. \& Arnau, L. M. (1999). Special education law: A review and analysis. FOCUS on 
legal issues for school administrators. Arlington, VA: Educational Research Service. (ERIC Document Reproduction Service No. ED437714)

DiPaola, M. F., \& Walther-Thomas, C. (2003). Principals and special education: The critical role of school leaders (COPSSE Document No. lB-7E). Gainesville, FL: University of Florida, Center on Personnel Studies in Special Education.

Education for All Handicapped Children Act of 1975, (Pub. L. No 94-142), 20 USC $§ 1400$ et seq.

Finkenbinder, R. L. (1981). Special education administration and supervision: The state of the art. Journal of Special Education, 15(4), 485-495.

Forgnone, C, \& Collings, G. D. (1975). State Certification-Endorsement in Special Education Administration. Journal of Special Education, 9(1), 5-9.

Forsyth, P.B, \& Murphy, J. (1997). A decade of changes: Analysis and comment. In J. Murphy \& P.B. Forsyth (Eds.), Educational administration: A decade of reform (pp. 253-272). Thousand Oaks, CA: Corwin.

Gerber, M. M. (1996). Reforming special education: Beyond inclusion. In C. Christensen \& Rizvi, F. (Eds.), Disability and the dilemmas of education and justice (pp.145-164). Philadelphia, PA: Open University Press.

Glanz, J. (1998). Histories, antecedents, and legacies of school supervision. In G.R. Firth \& E.F. Pajak (Eds.), Handbook of Research on school supervision (pp. 39-79). New York, NY: Simon \& Schuster Macmillan.

Goor, M. B. (1995). Attracting, selecting, and facilitating the growth of quality special educators. In M. Goor (Ed.), Leadership for special education administration: A case-based 
approach (pp. 109-129). Fort Worth, TX: Harcourt Brace.

Goor, M. B. (1995). Collaborative principals are the key. In M. Goor (Ed.), Leadership for special education administration: A case-based approach (pp. 130-147). Fort Worth, TX: Harcourt Brace.

Goor, M. B. (1995). Leadership. In M. Goor (Ed.), Leadership for special education administration: A case-based approach (pp. 3-22). Fort Worth, TX: Harcourt Brace.

Goor, M. B., Schwenn, J. O., \& Boyer, L. (1997). Preparing principals for leadership in special education. Intervention in School and Clinic, 32(3), 133-142.

Griffith, K. G., \& Cooper, M. J. (2002). Are educational administrators prepared to meet the needs of employees with disabilities? Rural Special Education Quarterly, 21(3), 21-29.

Harris, I. B. (1993). New expectations for professional competence. In L. Curry \& J. F. Wergin (Eds.), Educating professionals: Responding to new expectations for competence and accountability (pp. 17-52). San Francisco, CA: Jossey-Bass.

Harris, B. M., \& King, J. D. (1975). Competency specifications for instructional leadership personnel, \#7 (rev.). Austin, TX: Special Education Supervisor Training Project, The University of Texas at Austin.

Hehir, T. F. (1999). The changing roles of special education leadership in the next millennium: Thoughts and reflections. Journal of Special Education Leadership, 12(1), 3-8.

Hooper Jr., H. H.(Buddy), Pankake, A., \& Schroth G. (1999). Inclusion in rural school districts: Where is the superintendent?. Rural Special Education Quarterly, 18, 23-28.

Huefner, D. S. (1997). The legalization and federalization of special education. In J. W. Lloyd, E. J. Kameenui, \& D. Chard, D. (Eds.), Issues in educating students with disabilities 
Supervision in special education (pp. 343-363). Mahwah, NJ: Lawrence Erlbaum Associates, Inc.

Individuals with Disabilities Education Act Amendments of 1997, (Pub. L. No 105-17), 20 U. S. C. $\S 1400$ et seq.

Individuals with Disabilities Education Act of 1990, (Pub. L No 101-476) 20 USC §1400 et seq. Individuals with Disabilities Education Act of 2004, (Pub. L No 108-446) 20 USC §1400 et seq. Jones, P. R., \& Wilkerson, W. R. (1975). Preparing special education administrators. Theory into practice, 14, 105-109.

Kauffman, J. M., \& Hallahan, D. P. (1997). A diversity of restrictive environments: Placement as a problem of social ecology. In J. W. Lloyd, E. J. Kameenui, \& D. Chard (Eds.), Issues in educating students with disabilities Supervision in special education (pp. 325343). Mahwah, NJ: Lawrence Erlbaum Associates, Inc.

Krathewohl, D. R. (1998). Methods of educational and social science research. An integrated approach. ( $2^{\text {nd }}$. ed.). Long Grove, IL: Waveland Press, Inc.

Larson, D, \& Wheeler, J. R. (1995). Advancing technology: The on-line administrator. In M. Goor (Ed.), Leadership for special education administration: A case-based approach (pp. 249-267). Fort Worth, TX: Harcourt Brace.

Lee, G. V. (1993). New images of school leadership: Implications for professional development. Journal of Staff Development, 143, 2-7.

Lincoln, Y., \& Guba, E. (1985). Naturalistic inquiry. Newbury Park, CA: Sage Publications, Inc. Lipsky, D. K., \& Gartner, A. (1996). Equity requires inclusion: The future for all students with disabilities. In C. Christensen \& F. Rizvi (Eds.), Disability and the dilemmas of education 
and justice (pp. 145-164). Philadelphia, PA: Open University Press.

Maycut, P., \& Morehouse, R. (1994). Beginning qualitative research: A philosophic and practical guide. Bristol, PA: Falmer Press.

Martin, R. (2001). Special education law: Special education is all about civil rights. Retrieved Nov. 21, 2004, from Special Education Advocacy Strategies Web site: http:www.reedmartin.com/specialeducationlawin2001.html.

Meyen, E. L. (1995). Legislative and programmatic foundations of special education. In E. L.Meyen \& T. M. Skrtic (Eds.), Special education and student disability: An introduction. Traditional, emerging, and alternative perspectives (pp.33-95). Denver, CO: Love.

Mertler, C. A., \& Charles, C. M. (2005). Introduction to educational research. (5 ${ }^{\text {th }}$ ed.), Boston, MA: Pearson.

Mills v. Boards of Education , 348 F. Supp. 866 (D.DC 1972).

Monteith, D. (2000). Professional development for administration in special education: Evaluation of a program for underrepresented personnel. Teacher Education and Special Education, 23(4), 281-289.

Marshall, C., \& Rossman, G. B. (1989). Designing qualitative research. Newbury Park, CA: Sage Publications.

No Child Left Behind Act of 2002, (Pub. L. No 107-110), 20 USC § 6301 et seq. North Carolina Comprehensive System of Professional Development Report (1991-1995). Raleigh, NC: North Carolina Department of Public Instruction.

Patton, M. Q. (1990). Qualitative evaluation and research methods. (2 ${ }^{\text {nd }}$ ed.), Beverly Hills, CA: 
Sage.

Patton, M. Q. (1990). Qualitative research and evaluation methods. (3 ${ }^{\text {rd }}$ ed.), Thousand Oaks, CA: Sage.

Payne, S. L. (1951). The art of asking questions. Princeton, NJ: Princeton University Press.

Pazey. B. (1993, October). The missing link for the administration of special education: The ethic of care. Paper presented at the conference of the University Council of Education Administration, Houston, TX.

Pennsylvania Association for Retarded Citizens v. Commonwealth of Pennsylvania, 334 F. Supp. 1257 (E.D. PA 1971).

Powers, S., Rayner, S., \& Gunter, H. (2001). Leadership in inclusive education: A professional development agenda for special education. British Journal of Special Education, 28(3), 5.

Prillaman, D., \& Richardson, R. (1985). State certification-endorsement requirements for special education administrators. The Journal of Special Education, 12(2), 231-236.

Sage, D. (1981). Administration of special education. In J.M. Kauffman \& D.P. Hallahan (Eds.), Handbook of special education. Englewood Cliffs, NJ: Prentice Hall, Inc.

Rockert, J. F. (1982). The changing role of the information system executive: A critical success factor perspective. Sloan Management Review, 24, 3-13.

Schnaiberg, L., (1995). Turnover among state special education directors sparks a concern. Education Week, 14(17), 12.

Schwenn, J.O. (1995). Who controls the purse strings controls the programs. In M. Goor (Ed.), Leadership for special education administration: A case-based approach (pp. 61-82). Fort Worth, TX: Harcourt Brace. 
Shaw, B. C. (1996). Reasonable accommodation of disabled employees: A comprehensive case law reference. Alexandria, VA: National School Boards Association. (ERIC Document Reproduction Service No. ED399638)

Silverman. D. (1993). Interpreting qualitative data: Methods for analyzing talk, text, and interaction. Thousand Oaks, CA: SAGE.

Simpson, R.L., \& Myles, B. S. (1993). General education collaboration: A model for successful mainstreaming. In E. L. Myen, G. A. Vergason, \& R. Whelen (Eds.), Education students with mild disabilities (pp. 49-63). Denver, CO: Love.

Spady, W. G. (1988). Organizing for results: The basis of authentic restructuring and reform. Educational Leadership, 46, 4-8.

Students with disabilities and special education law (21 $1^{\text {st }}$ ed.). (2004). Malvern, PA: Center for Education and Employment.

Strauss, A. L., \& Corbin, J. M. (1998). Basics of qualitative research: Techniques and procedures for developing grounded theory. $\left(2^{\text {nd }}\right.$ ed). Thousand Oaks, CA: SAGE.

Swan, W. W. (1998). Supervision in special education. In G. R. Firth \& E. F. Pajak (Eds.), Handbook of research on school supervision (pp. 529-542). New York, NY: Simon \& Schuster Macmillan.

Tomlison, S. (1996). Conflicts and dilemmas for professionals in special education. In C. Christensen \& F. Rizvi (Eds.), Disability and the dilemmas of education and justice (pp. 175-186). Philadelphia, PA: Open University Press.

Tracy, S. J. (1998). Models and approaches. In G. R. Firth \& E. F. Pajak (Eds.), Handbook of research on school supervision (pp. 80-108). New York, NY: Simon \& Schuster 
Macmillan.

Turnbull, H. R. (1986). Free appropriate public education: The law and children with disabilities. Denver, Co: Love.

US Department of Education, (n.d.). History of IDEA: Twenty-five years of progress in educating children with disabilities through IDEA. Retrieved Nov. 22, 2004, from ED.gov Web site: http://www.ed.gov/policy/speced/leg/idea/history.html.

West Virginia Department of Education. (2003). Procedures for second month report, idea, part b annual data reports. Prepared by S. McQuain, Special education reports for accountability. Charleston, WV: Office of Special Education.

What every special educator must know: Ethics, standards, and guidelines for special educators (5 ${ }^{\text {th }}$ ed.). (2003). Arlington, VA: Council for Exceptional Children.

Whitworth, J. E., \& Hatley, R. V. (1979). Certification and special education leadership personnel: An analysis of state standards. Journal of Special Education, 13(3), 297-305.

Wigle, S. E., \& Wilcox, D. J. ((2002). Special education directors and their competencies on CEC-identified skills. Education, 123, 276-289.

Yin, R. K. (1994). Case study research: Design and methods. $2^{\text {nd }}$ Edition. Thousand Oaks, CA: Sage.

Zadnik, D. J. (1985). Critical success factors of special education administrators. Unpublished doctoral dissertation. Bloomington, IN: Indiana University.

Zigmond, N. (1997). Educating students with disabilities: The future of special education. In J. W. Lloyd, E. J. Kameenui, \& D. Chard (Eds.), Issues in educating students with 
disabilities: Supervision in special education (pp. 377-390). Mahwah, NJ: Lawrence

Erlbaum Associates, Inc. 


\section{Appendix A}

\section{Demographics Total Respondents}


Appendix A

\begin{tabular}{|c|c|c|c|c|c|c|}
\hline \multicolumn{7}{|c|}{$\begin{array}{c}\text { Directors of Special Education Perceptions Survey Demographics } \\
\text { Total Respondents }=45\end{array}$} \\
\hline & YES & NO & & & & \\
\hline $\begin{array}{l}\text { I have taught special education } \\
\text { classes in the public school setting. }\end{array}$ & $\begin{array}{c}33 \\
(73.3 \%)\end{array}$ & $\begin{array}{c}12 \\
(26.7 \%)\end{array}$ & & & & \\
\hline $\begin{array}{l}\text { I currently have an administrative } \\
\text { endorsement. }\end{array}$ & $\begin{array}{c}35 \\
(77.8 \%)\end{array}$ & $\begin{array}{c}10 \\
(22.2 \%)\end{array}$ & & & & \\
\hline $\begin{array}{l}\text { My administrative endorsement is } \\
\text { through a general administration } \\
\text { program. }\end{array}$ & $\begin{array}{c}33 \\
(94.3 \%)\end{array}$ & $\begin{array}{l}2 \\
(5.7 \%)\end{array}$ & & & & \\
\hline \multirow[t]{2}{*}{$\begin{array}{l}\text { My administrative endorsement is } \\
\text { through a program specifically } \\
\text { designed for the administration of } \\
\text { special education programs. }\end{array}$} & $\begin{array}{c}2 \\
(5.7 \%)\end{array}$ & $\begin{array}{c}33 \\
(94.3 \%)\end{array}$ & & & & \\
\hline & $\begin{array}{c}1-5 \\
\text { years }\end{array}$ & $\begin{array}{c}6-10 \\
\text { years }\end{array}$ & $\begin{array}{l}11-15 \\
\text { years }\end{array}$ & $\begin{array}{l}16-20 \\
\text { years }\end{array}$ & $\begin{array}{l}21-25 \\
\text { years }\end{array}$ & $\begin{array}{c}26 \\
\text { years } \\
\text { plus }\end{array}$ \\
\hline \multirow[t]{2}{*}{ I have been in my current position: } & $\begin{array}{c}18 \\
(40.0 \%)\end{array}$ & $\begin{array}{c}15 \\
(33.3 \%)\end{array}$ & $\begin{array}{c}5 \\
(11.1 \%)\end{array}$ & $\begin{array}{c}2 \\
(4.4 \%)\end{array}$ & $\begin{array}{c}3 \\
(6.8 \%) \\
\end{array}$ & $\begin{array}{c}2 \\
(4.4 \%)\end{array}$ \\
\hline & Bachelors & Masters & Doctorate & & & \\
\hline \multirow[t]{2}{*}{ My highest educational degree is: } & $\begin{array}{c}0 \\
(0.0 \%)\end{array}$ & $\begin{array}{c}40 \\
(88.9 \%)\end{array}$ & $\begin{array}{c}5 \\
(11.1 \%)\end{array}$ & & & \\
\hline & $\begin{array}{l}\text { Virginia } \\
\text { Tech }\end{array}$ & MU & WVU & $\begin{array}{l}\text { Frostburg } \\
\text { State }\end{array}$ & $\begin{array}{c}\text { WV } \\
\text { cOGS }\end{array}$ & $\begin{array}{l}\text { Salem } \\
\text { U. }\end{array}$ \\
\hline \multirow[t]{2}{*}{$\begin{array}{l}\text { I received my administrative } \\
\text { endorsement from: }\end{array}$} & $\begin{array}{c}2 \\
(5.7 \%)\end{array}$ & $\begin{array}{c}12 \\
(34.3 \%)\end{array}$ & $\begin{array}{c}13 \\
(37.1 \%) \\
\end{array}$ & $\begin{array}{c}1 \\
(2.9 \%) \\
\end{array}$ & $\begin{array}{c}5 \\
(14.3 \%)\end{array}$ & $\begin{array}{c}2 \\
(5.7 \%)\end{array}$ \\
\hline & $\begin{array}{l}1970- \\
1979\end{array}$ & $\begin{array}{l}1980- \\
1989\end{array}$ & $\begin{array}{l}1990- \\
1999\end{array}$ & $2000-$ & & \\
\hline $\begin{array}{l}\text { I received my administrative } \\
\text { endorsement in the year: }\end{array}$ & $\begin{array}{c}3 \\
(8.6 \%)\end{array}$ & $\begin{array}{c}8 \\
(22.9 \%)\end{array}$ & $\begin{array}{c}15 \\
(42.8 \%)\end{array}$ & $\begin{array}{c}9 \\
(25.7 \%)\end{array}$ & & \\
\hline
\end{tabular}


Perceptions of Knowledge and Training 141

Appendix B

Demographics Males 


\section{Appendix B}

\begin{tabular}{|c|c|c|c|c|c|c|}
\hline \multicolumn{7}{|c|}{$\begin{array}{r}\text { Directors of Special Education Perceptions Survey } \\
\text { Total Male Respondents }=18\end{array}$} \\
\hline & YES & NO & & & & \\
\hline $\begin{array}{l}\text { I have taught special education } \\
\text { classes in the public school setting. }\end{array}$ & $\begin{array}{c}9 \\
(50.0 \%)\end{array}$ & $\begin{array}{c}9 \\
(50.0 \%)\end{array}$ & & & & \\
\hline $\begin{array}{l}\text { I currently have an administrative } \\
\text { endorsement. }\end{array}$ & $\begin{array}{c}13 \\
(72.2 \%)\end{array}$ & $\begin{array}{c}5 \\
(27.8 \%)\end{array}$ & & & & \\
\hline $\begin{array}{l}\text { My administrative endorsement is } \\
\text { through a general administration } \\
\text { program. }\end{array}$ & $\begin{array}{c}12 \\
(92.3 \%)\end{array}$ & $\begin{array}{c}1 \\
(7.7 \%)\end{array}$ & & & & \\
\hline \multirow[t]{2}{*}{$\begin{array}{l}\text { My administrative endorsement is } \\
\text { through a program specifically } \\
\text { designed for the administration of } \\
\text { special education programs. }\end{array}$} & $\begin{array}{c}1 \\
(7.7 \%)\end{array}$ & $\begin{array}{c}12 \\
(92.3 \%)\end{array}$ & & & & \\
\hline & $\begin{array}{c}1-5 \\
\text { years }\end{array}$ & $\begin{array}{l}6-10 \\
\text { years }\end{array}$ & $\begin{array}{l}11-15 \\
\text { years }\end{array}$ & $\begin{array}{l}16-20 \\
\text { years }\end{array}$ & $\begin{array}{l}21-25 \\
\text { years }\end{array}$ & $\begin{array}{l}26 \\
\text { years } \\
\text { plus }\end{array}$ \\
\hline \multirow[t]{2}{*}{$\begin{array}{l}\text { I have been in my current } \\
\text { position: }\end{array}$} & $\begin{array}{c}6 \\
(33.3 \%) \\
\end{array}$ & $\begin{array}{c}4 \\
(22.2 \%) \\
\end{array}$ & $\begin{array}{c}3 \\
(16.7 \%) \\
\end{array}$ & $\begin{array}{c}2 \\
(11.1 \%)\end{array}$ & $\begin{array}{c}2 \\
(11.1 \%)\end{array}$ & $\begin{array}{c}1 \\
(5.6 \%)\end{array}$ \\
\hline & Bachelors & Masters & Doctorate & & & \\
\hline \multirow[t]{2}{*}{ My highest educational degree is: } & $\begin{array}{c}0 \\
(0.0 \%)\end{array}$ & $\begin{array}{c}15 \\
(83.3 \%) \\
\end{array}$ & $\begin{array}{c}3 \\
(16.7 \%) \\
\end{array}$ & & & \\
\hline & $\begin{array}{l}\text { Virginia } \\
\text { Tech }\end{array}$ & MU & $\overline{\text { WVU }}$ & $\begin{array}{l}\text { Frostburg } \\
\text { State }\end{array}$ & $\begin{array}{c}\text { WV } \\
\text { cOGS }\end{array}$ & $\begin{array}{l}\text { Salem } \\
\text { U. }\end{array}$ \\
\hline \multirow[t]{2}{*}{$\begin{array}{l}\text { I received my administrative } \\
\text { endorsement from: }\end{array}$} & $\begin{array}{c}1 \\
(7.7 \%)\end{array}$ & $\begin{array}{c}4 \\
(30.7 \%) \\
\end{array}$ & $\begin{array}{c}6 \\
(46.2 \%) \\
\end{array}$ & $\begin{array}{c}1 \\
(7.7 \%) \\
\end{array}$ & $\begin{array}{c}1 \\
(7.7 \%)\end{array}$ & $\begin{array}{c}0 \\
(0.0 \%)\end{array}$ \\
\hline & $\begin{array}{c}1970- \\
1979\end{array}$ & $\begin{array}{c}1980- \\
1989\end{array}$ & $\begin{array}{c}1990- \\
1999\end{array}$ & 2000- & & \\
\hline $\begin{array}{l}\text { I received my administrative } \\
\text { endorsement in the year: }\end{array}$ & $\begin{array}{c}3 \\
(23.1 \%)\end{array}$ & $\begin{array}{c}5 \\
(38.5 \%)\end{array}$ & $\begin{array}{c}3 \\
(23.1 \%)\end{array}$ & $\begin{array}{c}2 \\
(15.3 \%)\end{array}$ & & \\
\hline
\end{tabular}


Perceptions of Knowledge and Training 143

Appendix C

Demographics Females 


\section{Appendix C}

\begin{tabular}{|c|c|c|c|c|c|c|}
\hline \multicolumn{7}{|c|}{$\begin{array}{c}\text { Directors of Special Education Perceptions Survey Demographics } \\
\text { Total Female Respondents }=27\end{array}$} \\
\hline & YES & NO & & & & \\
\hline $\begin{array}{l}\text { I have taught special education } \\
\text { classes in the public school setting. }\end{array}$ & $\begin{array}{c}24 \\
(88.9 \%) \\
\end{array}$ & $\begin{array}{c}3 \\
(11.1 \%) \\
\end{array}$ & & & & \\
\hline $\begin{array}{l}\text { I currently have an administrative } \\
\text { endorsement. }\end{array}$ & $\begin{array}{c}22 \\
(81.5 \%)\end{array}$ & $\begin{array}{c}5 \\
(18.5 \%)\end{array}$ & & & & \\
\hline $\begin{array}{l}\text { My administrative endorsement is } \\
\text { through a general administration } \\
\text { program. }\end{array}$ & $\begin{array}{c}21 \\
(95.5 \%)\end{array}$ & $\begin{array}{c}1 \\
(4.5 \%)\end{array}$ & & & & \\
\hline \multirow[t]{2}{*}{$\begin{array}{l}\text { My administrative endorsement is } \\
\text { through a program specifically } \\
\text { designed for the administration of } \\
\text { special education programs. }\end{array}$} & $\begin{array}{c}1 \\
(4.5 \%)\end{array}$ & $\begin{array}{c}21 \\
(95.5 \%) \\
\end{array}$ & & & & \\
\hline & $\begin{array}{c}1-5 \\
\text { years }\end{array}$ & $\begin{array}{c}6-10 \\
\text { years }\end{array}$ & $\begin{array}{l}11-15 \\
\text { years }\end{array}$ & $\begin{array}{l}16-20 \\
\text { years }\end{array}$ & $\begin{array}{l}21-25 \\
\text { years }\end{array}$ & $\begin{array}{c}26 \\
\text { years } \\
\text { plus }\end{array}$ \\
\hline \multirow[t]{2}{*}{ I have been in my current position: } & $\begin{array}{c}12 \\
(44.4 \%) \\
\end{array}$ & $\begin{array}{c}11 \\
(40.7 \%) \\
\end{array}$ & $\begin{array}{c}2 \\
(7.5 \%)\end{array}$ & $\begin{array}{c}0 \\
(0.0 \%)\end{array}$ & $\begin{array}{c}1 \\
(3.7 \%)\end{array}$ & $\begin{array}{c}1 \\
(3.7 \%)\end{array}$ \\
\hline & Bachelors & Masters & Doctorate & & & \\
\hline \multirow[t]{2}{*}{ My highest educational degree is: } & $\begin{array}{c}0 \\
(0.0 \%)\end{array}$ & $\begin{array}{c}25 \\
(92.6 \%)\end{array}$ & $\begin{array}{c}2 \\
(7.4 \%)\end{array}$ & & & \\
\hline & $\begin{array}{l}\text { Virginia } \\
\text { Tech }\end{array}$ & MU & WVU & $\begin{array}{l}\text { Frostburg } \\
\text { State }\end{array}$ & $\begin{array}{l}\text { WV } \\
\text { COGS }\end{array}$ & $\begin{array}{l}\text { Salem } \\
\text { U. }\end{array}$ \\
\hline \multirow[t]{2}{*}{$\begin{array}{l}\text { I received my administrative } \\
\text { endorsement from: }\end{array}$} & $\begin{array}{c}1 \\
(4.5 \%)\end{array}$ & $\begin{array}{c}9 \\
(40.9 \%)\end{array}$ & $\begin{array}{c}7 \\
(31.8 \%)\end{array}$ & $\begin{array}{c}0 \\
(0.0 \%)\end{array}$ & $\begin{array}{c}3 \\
(13.7 \%)\end{array}$ & $\begin{array}{c}2 \\
(9.1 \%)\end{array}$ \\
\hline & $\begin{array}{l}1970- \\
1979\end{array}$ & $\begin{array}{l}1980- \\
1989\end{array}$ & $\begin{array}{l}1990- \\
1999\end{array}$ & $2000-$ & & \\
\hline $\begin{array}{l}\text { I received my administrative } \\
\text { endorsement in the year: }\end{array}$ & $\begin{array}{c}0 \\
(0.0 \%)\end{array}$ & $\begin{array}{c}3 \\
(13.6 \%)\end{array}$ & $\begin{array}{c}12 \\
(54.5 \%)\end{array}$ & $\begin{array}{c}7 \\
(31.9 \%)\end{array}$ & & \\
\hline
\end{tabular}


Perceptions of Knowledge and Training 145

Appendix D

Permission to Reprint 


\section{$4 . \begin{aligned} & \text { Council for } \\ & \text { Exceptional } \\ & \text { Children }\end{aligned}$}

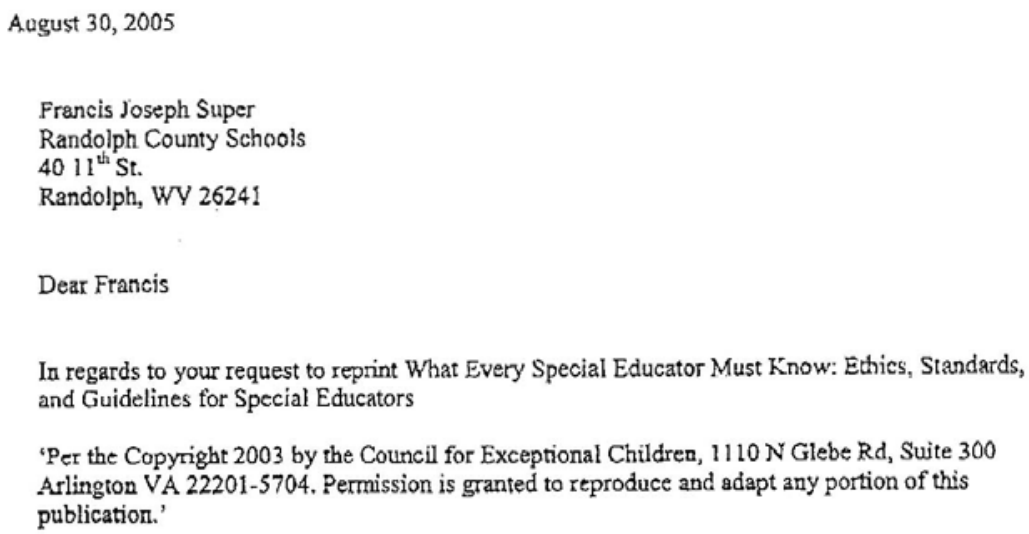




\section{(;)pro.ed \\ journals}

Scptember 13,2005

Francis Joseph Super

Dircctor of Special Education

Randolph County Schools

401 !th Street

Elkins, WV 26241

Dear Mr. Super:

Concerning your request to reprint Figure 2 on page 164 from the following article

Crockett, J. B. (2002). Special education's rolc in preparing responsible li:aders for inclusive schools. Remedial and Special Education, 23, 157-168.

Upon your acceptance of the following conditions, PRO-ED grants to you a nonexclusive, one-time license to reprint the material. This grant is limited to worldwide publication of the work in the English language.

\section{Conditions:}

1. That use of this material be limited to the manner indicated in the request.

2. That both the source and publisher be acknowledged, preferably in the folloving form: From "Title of Article" by A. B. Author and C. D. Author, date, Title of Journal. V.1. No. pp. nos. Copyright (date) by PRO-ED. Inc. Reprinted with permission.

3. There is no royalty fee for use as indicated in the reguest.

Sincercly,

Peggy Kipping, MEd, CCC-SLP

Pcriodicals Directo: 


\section{Lofe Publishing Co \\ 9101 E. Kenyon Ave. Ste. 2200 \\ Denver CO 80237 \\ BOOK REPRODUCTION PERMISSION REQUEST}

This is a response to a request for permission to reproduce copyright material from Love Publishing Company for use in a college or university class or for use in school district staff development. This permission does not extend to any material appearing in our publication with credit to another source. Permission to use such material must be obtained from the original copyright holder.

\section{ORDER INFORMATYON}

\section{Customer Jot Supere}

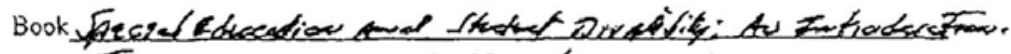

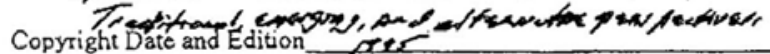

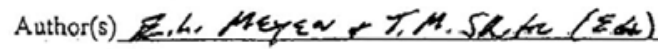

Exact pages to be Reproduced___ $\quad L \quad$ Number of pages_ 79

\section{COST INTORMATION}

Fees: $\$ 15$ per copy. Minimum charge of $\$ 25.00$ for all permission requests.

Calcutation:

pages $\mathrm{X}$ copies $\times \$ .15=\$$

Permission Approval Information

This permission is valid only for the quantity specified above and is not valid for reproduction in a hank or for other purposes. A credit line is to be stated as follows:

From (title, author, publication date, and page numbers). Reproduced by permission of Love Publishing Company. Permission is not valid until this form has been signed and fces are PAID. A. COPY OF THIS FORM MUST BE RETURNED WITH PAYMENT TO: Love Publishing $C$.

9101 E. Kenyon Ave. Ste. 2200

Denver, CO 80237

Date 8/31/05

Authorized Approval_ 


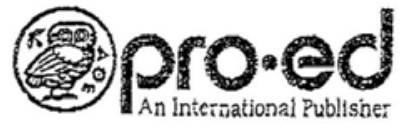

journals

August 30,2005

Francis Joseph Super

Director of Special Education

Randolph County Schools

4011 th Street

Elkins, WV 26241

Dear Mr. Super:

Concerning your request to reprint Table 2 on page 354 from the following article

Arick, J. R. \& Krug, D. A.. (1993). Special education administrators in the: US:

Perceptions on policy and personnel issues. Journal of Special Education 2T, 348-364.

Upon your acceptance of the following conditions, PRO-ED grants to you a

nonexclusive, one-time license to reprint the material. This grant is limited to wor ldwide publication of the work in the English language.

\section{Conditions:}

1. That use of this material be limited to the manner indicated in the request.

2. That both the source and publisher be acknowledged, preferably in the following form: From "Title of Article" by A. B. Author and C. D. Author, date, Title of Joumal. Vs!l. No., pp. nos. Copyright (date) by PRO-ED, Inc. Reprinted with permission.

3. There is no royalty fee for use as indicated in the request.

Sincerely,

Peggy Kipping, MEd, CCC-SLP

Periodicals Director 
Permission

Subject: Permission

From: "Clifford, Anna" < Anna.Clifford@sagepub.com>

Date: Thu, 6 Oct 2005 11:05:34 -0700

To:<fsuper@access.k12.wv.us>

Dear Mr. Super,

Please consider this written permission to use the material from EDUCATING ALL

STUDENTS TOGETHER; HOW SCHOOL LEADERS CREATE UNIFIED SYSTEMS, for your dissertation/thesis. There is no charge for this and I wish you the best of luck.

Please let me know if you need anything further.

Sincerely,

Anna Clifford

Permissions \& Translations Administrator

Sage Publications

2455 Teller Road

Thousand Oaks, CA 91320

805-410-7713

805-376-9562 fax

anna.clifford@sagepub.com 
Sevieing rights and pormingion ios

THOMSOIN

Thomson Brokks/Cole - Thomson Course Technology - Thomson Custom Publishing.

thomson Nelson in Canaja. Thomson Peterson's. Tnomson South. Western. Thomson Wageworth

LEARTINES

10 Davis Drive, Belmom, Calitomia 94902 USA Phone: 800 739-2214 Fax: 890 790.22:5

Emati: thomsonrights@thomson.com

Submit all requests online at www.thomsonrights.com.

$09 / 01 / 2005$

Francis J Super

4011 th Street

Randolph County Schools..Sped

Elkins, WV 26241

Thank you for your interest in the following Waosworth material

Title: $\quad$ Special Education Administration: A Case-Based Approach ist edition

$\begin{array}{ll}\text { Author(s): } & \text { GOOR }\end{array}$

Publisher: Wadsworth

Specific malerial: "Collaboantive Principar's Responsibiities As a Leader of Special Education" page 137

Total pages: 1

For use by:

Name: Joe Super

School/University/Company:

Course title/number: Dissenation

Term of use: 2005

Intended use:

For inclusion in a research paper, master's thesis, doctoral dissertation, or manuscript to be prepared and submitted for publication. 11 at a later date a publishing contract is achieved, adcitional permission will be required.

The permission granted in this ietler extends only to material that is original to the aforementioned text. As the requestor, you will nee 1 to check all on-page credit references (as well as any other credit/acknowiedgement section(s) in the front and/or back of the book) 13 identify all materials reprinted therein by permission of another source. Please give special consideration to all photos, figures,

quotations, and any other material with a credit line attached. You are responsibie for obtaining separate permission from the copyrigl t

holder for use of all such material. For your convenience, we may also identify here beiow some materiai for which you will need to

obtain separate permission.

This credit line must appear on the first page of text selection and with each individual figure or photo:

From Special Education Administration. A Cesse-Based Approach 1st ecition by GOOR. 1995. Reprinted with

permission of Wadsworth, a division of Thomson Learning: www.thomsonrights.corn. Fax 800 730-2215.

Sincerely,

Audrey Pettengill

Media Permissions Editor 
Perceptions of Knowledge and Training 152

Appendix E

\section{Cover Letters}




\section{RANDOLPH COUNTY SCHOOLS/SPECIAL EDUCATION DEPARTMENT \\ $* 4011^{\text {th }}$ Street $*$ Elkins, WV $26241 *$ Ph \# 304-636-9150 * Fax \# 304-637-2516 * \\ F. Joseph Super \\ Director}

June 23, 2005

Dear Fellow Directors of Special Education,

Currently I am a doctoral student at West Virginia University. In partial fulfillment of the requirements of my dissertation, I am conducting this study. I am investigating the perceptions of special education directors related to their knowledge base and their preparation for their current position. My guiding research question is: What is the knowledge base special education directors feel they need to know in the field of special education administration? In-depth personal and phone interviews will provide support to the statistical information gained through this survey. It is my intention this study will provide a template for further research in this area and serve institutions of higher education in their efforts to deliver accountable graduate level administrative programs in the area of special education.

Because you are currently a director of special education, I respectfully ask you to participate in this study. Your participation is entirely voluntary and you do not have to respond to every item or question. Your anonymity and confidentiality will be maintained. My report will reflect only statistical information based on the entire subject population from West Virginia; no individuals will be singled out. You can refuse to participate or withdraw from the study at any time.

Please accept this invitation to participate in my study by filling out the survey. I believe that the answers I seek will be an important step in the overall effort being put forth by others to bring about a better understanding of how we can improve graduate level administration programs for directors of special education.

Sincerely yours,

F. Joseph “Joe” Super

(hdsurveycoverletter) 


\section{Dear Fellow Special Education Director,}

Currently I am a doctoral student at West Virginia University. In partial fulfillment of the requirements of my dissertation, I am conducting this study. I am investigating the perceptions of directors of special education regarding their knowledge base for their current position and the preparation they received in their graduate level administration programs. My guiding research question is: What is the knowledge base special education directors feel they need to know in the field of special education administration? The information gained from the personal and phone interviews will augment the statistical information provided through a survey to the general population of special education directors. It is my intention this study will provide a template for further research in this area and serve institutions of higher education in their efforts to deliver accountable graduate level administration programs in the area of special education.

Based on three sets of paired opposite factors related to your current leadership position in special education, I respectfully ask you to participate in the study by agreeing to personal and short telephone interviews. The personal and phone interviews will be audiotaped to ensure the accuracy of the findings. This material will be maintained in a secure area and the tapes will be shredded at the completion of the project. Your responses will remain anonymous and confidentiality will be maintained. The interview information will be used to provide a more complete picture of my study when related to the survey data. Your participation is entirely voluntary and you do not have to respond to every item or question. The report from the study will reflect what happens only in West Virginia. You can refuse to participate or withdraw from the study at any time.

Please accept this invitation to participate in my study. I believe that the answers I seek are an important step in the overall effort being put forth by others to bring about a better understanding of how we can improve the preparation of special education directors.

Sincerely yours,

\section{F. Joseph “Joe” Super}

(hdinterviewcoverletter) 
Appendix F

Descriptive Statistics

Summary

Gender

Endorsement 
Case Processing Summary

\begin{tabular}{|c|c|c|c|c|c|c|}
\hline & \multicolumn{6}{|c|}{ Cases } \\
\hline & \multicolumn{2}{|c|}{ Included } & \multicolumn{2}{|c|}{ Excluded } & \multicolumn{2}{|c|}{ Total } \\
\hline & $\mathrm{N}$ & Percent & $\mathrm{N}$ & Percent & $\mathrm{N}$ & Percent \\
\hline Scale1 * Gender & 35 & $77.8 \%$ & $\overline{10}$ & $22.2 \%$ & 45 & $100.0 \%$ \\
\hline Scale2 * Gender & 45 & $100.0 \%$ & 0 & $.0 \%$ & 45 & $100.0 \%$ \\
\hline Scale3 * Gender & 45 & $100.0 \%$ & 0 & $.0 \%$ & 45 & $100.0 \%$ \\
\hline $\begin{array}{l}\text { Scale } 1 * \text { I currently } \\
\text { have an administrative } \\
\text { endorsement. }\end{array}$ & 35 & $77.8 \%$ & 10 & $22.2 \%$ & 45 & $100.0 \%$ \\
\hline $\begin{array}{l}\text { Scale } 2 * \text { I currently } \\
\text { have an administrative } \\
\text { endorsement. }\end{array}$ & 45 & $100.0 \%$ & 0 & $.0 \%$ & 45 & $100.0 \%$ \\
\hline $\begin{array}{l}\text { Scale } 3 * \text { I currently } \\
\text { have an administrative } \\
\text { endorsement. }\end{array}$ & 45 & $100.0 \%$ & 0 & $.0 \%$ & 45 & $100.0 \%$ \\
\hline
\end{tabular}


Descriptive Statistics for Domains by Gender.

Scale1 Scale2 Scale3 * Gender

\begin{tabular}{|ll|r|r|r|}
\hline Gender & \multicolumn{1}{|c|}{ Scale1 } & \multicolumn{1}{|c|}{ Scale2 } & \multicolumn{1}{c|}{ Scale3 } \\
\hline Male & Mean & 17.6923 & 7.6111 & 11.8889 \\
& $\mathrm{~N}$ & 13 & 18 & 18 \\
& Std. Deviation & 3.52100 & 1.81947 & 3.02711 \\
& Median & 18.0000 & 8.0000 & 11.5000 \\
& Minimum & 10.00 & 5.00 & 8.00 \\
& Maximum & 23.00 & 12.00 & 20.00 \\
\hline Female & Mean & 19.9091 & 8.1852 & 10.5185 \\
& $\mathrm{~N}$ & 22 & 27 & 27 \\
& Std. Deviation & 4.84924 & 2.14901 & 2.39182 \\
& Median & 21.0000 & 8.0000 & 11.0000 \\
& Minimum & 8.00 & 5.00 & 6.00 \\
& Maximum & 28.00 & 12.00 & 15.00 \\
\hline Total & Mean & 19.0857 & 7.9556 & 11.0667 \\
& N & 35 & 45 & 45 \\
& Std. Deviation & 4.48115 & 2.02210 & 2.71695 \\
& Median & 19.0000 & 8.0000 & 11.0000 \\
& Minimum & 8.00 & 5.00 & 6.00 \\
& Maximum & 28.00 & 12.00 & 20.00 \\
\hline
\end{tabular}


Descriptive Statistic for Domains by having an Administrative Endorsement.

Scale1 Scale2 Scale3 * I currently have an administrative endorsement.

\begin{tabular}{|ll|r|r|r|}
\hline I currently have & Scale1 & Scale2 & Scale3 \\
\hline No & Mean & & 7.5000 & 11.5000 \\
& $N$ & & 10 & 10 \\
& Std. Deviation & & 1.77951 & 1.71594 \\
Median & & 7.5000 & 11.5000 \\
& Minimum & & 5.00 & 9.00 \\
& Maximum & & 11.00 & 15.00 \\
\hline Yes & & 8.0857 & 10.9429 \\
& Mean & 19.0857 & 35 & 35 \\
& Std. Deviation & 35 & 2.09160 & 2.95000 \\
& Median & 19.0000 & 8.0000 & 11.0000 \\
& Minimum & 8.00 & 5.00 & 6.00 \\
Maximum & 28.00 & 12.00 & 20.00 \\
\hline Mean & 19.0857 & 7.9556 & 11.0667 \\
& $N$ & 35 & 45 & 45 \\
& Std. Deviation & 4.48115 & 2.02210 & 2.71695 \\
& Median & 19.0000 & 8.0000 & 11.0000 \\
& Minimum & 8.00 & 5.00 & 6.00 \\
& Maximum & 28.00 & 12.00 & 20.00 \\
\hline
\end{tabular}

